UNIVERSIDADE DE SÃO PAULO

INSTITUTO DE QUÍMICA

\title{
Distribuição intracelular de enzimas digestivas e caracterização das $\beta$-glucosidases intestinais de Abracris flavolineata
}

\author{
Sandro Roberto Marana \\ Orientadora: Dra. Clélia Ferreira Terra
}

SÃo PAULO

1994 


\title{
"DIBTRIBUIÇÃo INTRACELULAR DE ENRIMAB DIGEBTIVAB E CARACTERIZAÇĀO DAB BETA-GLUCOBIDABEB INTEBTINAIS DE ABRACRI8 FLAVOLINEATA"
}

\section{BANDRO ROBERTO MARANA}

\author{
Dissertação de Mestrado submetida ao Instituto de \\ Química da Universidade de são Paulo como parte dos \\ requisitos necessários a obtenção do grau de Mestre em \\ Ciências - Área: Bioquímica. \\ Aprovada por:
}

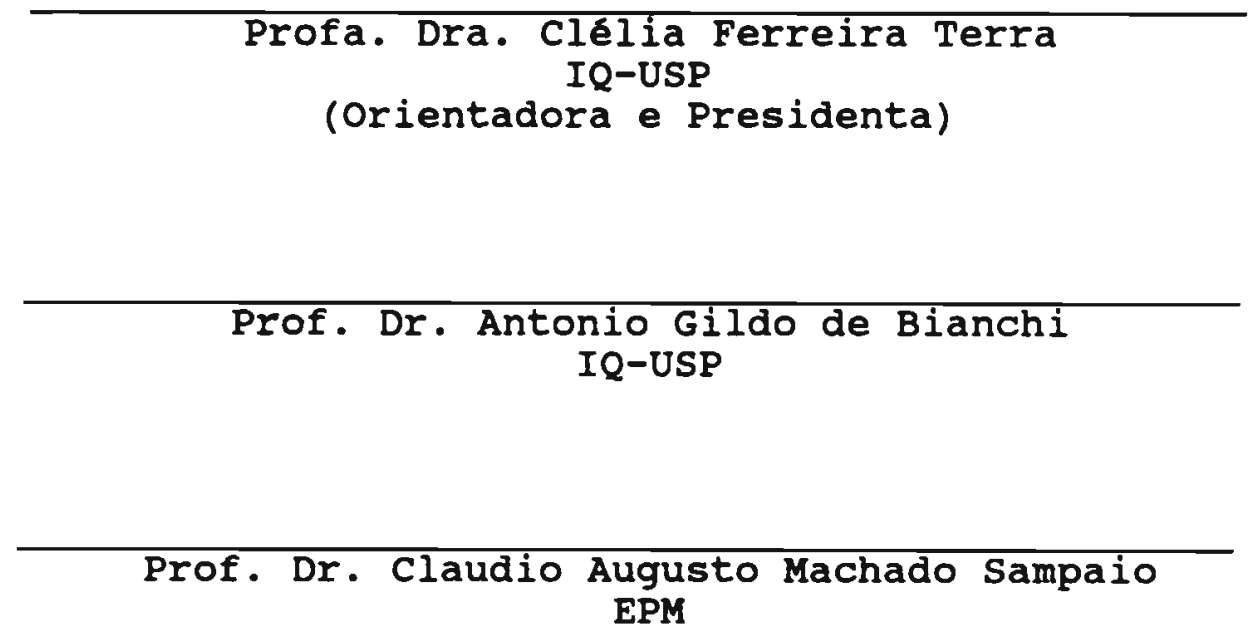

SÃo PAULO, SP

29 DE AGOSTO DE 1994 


\section{DEDICATÓRIA}

"Você me pergunta pela minha paixão, digo que estou encantado com uma nova invenção. Eu vou ficar nesta cidade, não vou voltar para o sertão, pois vejo vir vindo no vento o cheiro da nova estação. Eu sei de tudo na ferida viva do meu coração."

(Belchior)

Aos meus pais, Maria Luiza e José, que enxergaram além de seus olhos. 


\section{Agradecimentos}

$\mathrm{Na}$ realização deste trabalho contei com a colaboração de algumas instituições e várias pessoas, as quais gostaria de agradecer.'

Inicialmente, a minha orientadora Dra. Clélia Ferreira, pela dedicação, confiança, apoio, batepapos e amizade.

Ao Dr. Walter Ribeiro Terra, pela leitura da dissertação, sugestões, discussões, por transmitir-me - entusiasmo pela pesquisa científica desde os tempos da graduação e sobretudo pelo exemplo.

Aos companheiros de laboratório que de uma forma ou outra ensinaram-me muitas coisas: Adriana $N$. Capella, Beatriz P. Jordão, Carlos P. Silva, Plínio T. Cristofoletti e Rosana Regel

Aos antigos companheiros de laboratório, Adriana M. Klinkowstrom, Francisco J. A. Lemos, Gisela I. Bellinello, Jony H. Sugo e Terezinha T. Schumacker, pelas boas lembranças.

Aos alunos de iniciação cientifica, Adriana Lopes, Beatriz M.Baker., Cleonice da Silva, Rodolfo A. Salm e Tamara $R$. de Azevedo, por lembrarem-me de tempos passados. 
Aos meus colegas durante a iniciação científica, Maria Cristina P.O. Penteado, Marcella Faria e Paulo E.M. Ribolla pelo entusiasmo e amizade.

A Luiza Y. Nakabayashi, Sandra M. Fernandez e Suely de Oliveira, pela assistência técnica e amizade.

Ao Sr. João da Rocha (in memorian) pela dedicação no cultivo das couves e bons bate-papos.

A Claudinei C. Spirandelli, Edson R. da Silva, Márcio $H$. Otta, Matheus M. Villares, Nilberto C. Pereira, Paulo T. Sano e Ricardo Dislich, pois amigos de verdade não encontramos todos os dias.

AO CNPq, FINEP e FAPESP pelos auxílios financeiros concedidos ao laboratório e sobretudo a Fundação de Amparo à Pesquisa do Estado de São Paulo (FAPESP) pela concessão da bolsa de mestrado. 


\section{ÍNDICE}

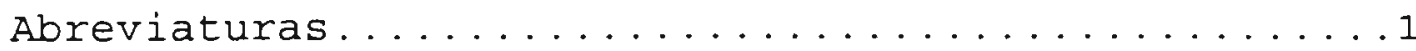

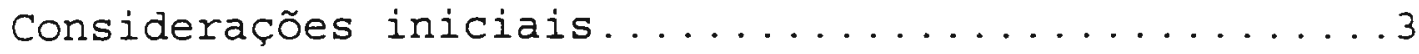

$1-$ Introdução......................

1.1 - Secreção de enzimas digestivas em insetos....4

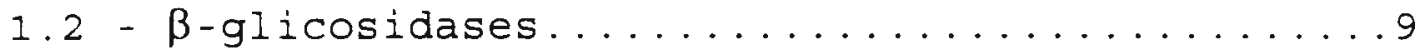

$1.2 .1-\beta$-glicosidases de mamíferos............10

$1.2 .2-\beta-g 1$ icosidases de insetos.................

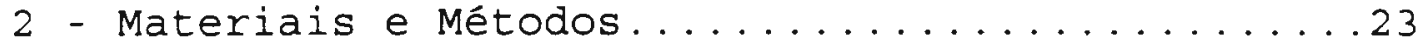

2.1 - Materiais biológicos................23

2.2 - Coleta de regurgitado................23

2.3 - Dissecção de adultos de A. flavolineata......23

2.4 - Homogeneização dos cecos anteriores de

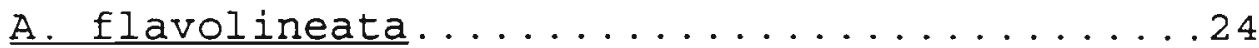

2.5 - Obtenção de frações com enzimas solúveis e particuladas a partir dos cecos anteriores de A. flavolineata em diferentes tempos após a refeição.........................25

2.6 - Centrifugação diferencial do homogeneizado dos cecos anteriores de A. flavolineata......26

2.7 - Ensaios enzimáticos e determinação de

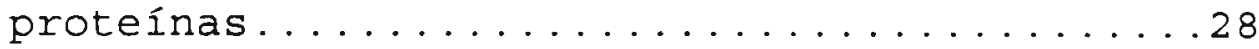

2.8 - Cromatografia em coluna de Superose 12 usando

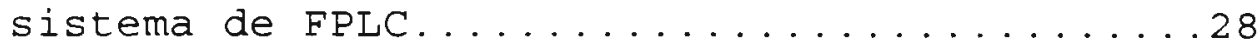

2.9 - Passagem do material coletado de Superose $12 \mathrm{em}$ coluna de Fast Desalting.....................

2.10 - Cromatografia em coluna de troca iônica Mono Q

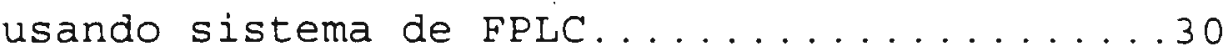


2.11 - Cromatografia em coluna de troca iônica Mono S usando sistema de FPLC..................

2.12 - Cromatografia hidrofóbica em coluna de AlquilSuperose usando sistema de FPLC.........32

2.13 - Cromatografia hidrofóbica em coluna de Octil-

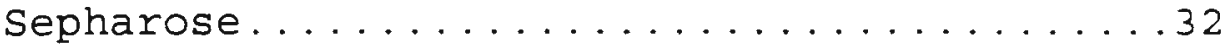

2.14-Eletroforese em cilindros de

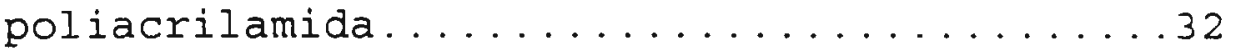

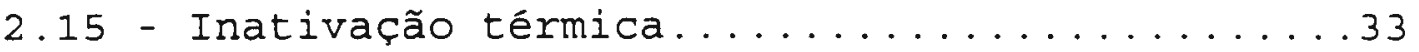

2.16 - Determinação do efeito da concentração de substratos na atividade de $\beta$-glicosidases...34

2.17 - Inibição da hidrólise de celobiose por pNфßglu e inibição da hidrólise de pN申ßglu por celobiose na $\beta$-glicosidase termoestável....35

2.18 - Inibição da hidrólise de octil $\beta$-glucosídeo por pN $\phi \beta g l u$ e inibição da hidrólise de pN $\phi \beta g l u$ por octil $\beta$-glicosideo....................

2.19 - Inibição da atividade de $\beta$-glicosidase por glucono $\delta$-lactona e $\gamma$ galactona lactona....37

2.20 - Determinação do pH ótimo de clivagem da celobiose e octil $\beta$-glucosídeo.............

2.21 - Determinação da configuração anomérica da Dglicose liberada pela $\beta$-glicosidase ativa

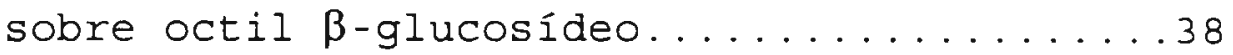

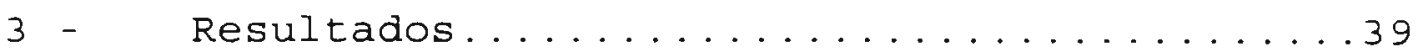

3.1 - Distribuição intracelular de enzimas digestivas em diferentes períodos após uma

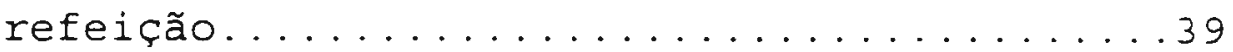

3.2 - Distribuição subcelular de enzimas digestivas presentes nos cecos anteriores.........43 
3.3 - Purificação de $\beta$-glicosidases............49

3.4 - Caracterização das $\beta$-glicosidases de Abracris

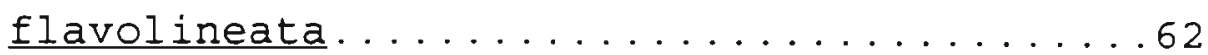

3.4.1 - Propriedades da celobiase - aril $\beta$ glucosidase...................62

3.4 .2 - Propriedades da alquil $\beta$-glucosidase......71

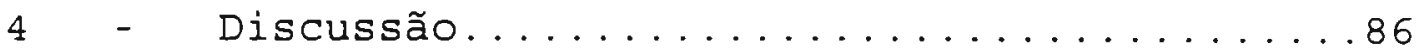

4.1 - Determinação da distribuição subcelular de subcelular de enzimas digestivas e seus mecanismos de secreção............86

4.2 - Purificação das $\beta$-glicosidases de $\underline{A}$.

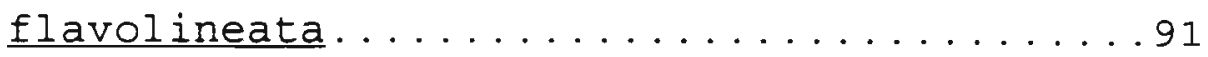

4.2.1 - Propriedades e funçào da celobiase-aril $\beta$ -

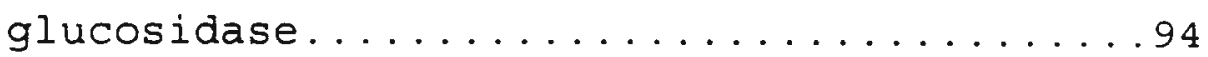

4.2.2 - Propriedades e função da alquil $\beta$-glucosidase

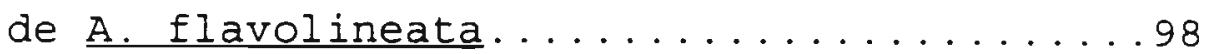

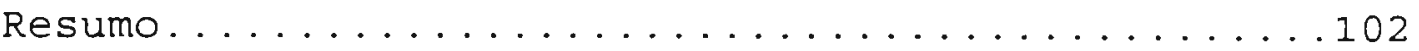

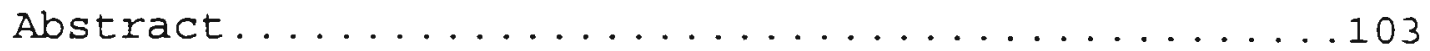

Referências bibliográficas.................... 104

Curriculum vitae...................... 


\section{Abreviaturas}

\section{A}

alquil $\beta g l u$

BAPA

CMC

$\operatorname{decil\beta glu}$

FPLC

Gly-Leu

heptilßglu

hexilßglu

$\mathrm{Ka}$

$\mathrm{Km}$

$\mathrm{Ki}$

$\mathrm{LDH}$

LpNA

Metilßglu

$\mathrm{Mr}$

nonilßglu

octiligglu

$\because \mathrm{P}$

$\mathrm{pI}$

$\mathrm{pN} \phi \beta g l u$

$S$

SDH ativador

alquil beta glucosídeo

benzoil arginina para

nitroanilida

concentração micelar crítica

decil beta glucosídeo

Fast Protein Liquid

Chromatography

Glicil-leucina

heptil beta glucosídeo

hexil beta glucosídeo

constante de dissociação do

complexo enzima-ativador

constante de Michaelis

constante de dissociação do

complexo enzima-inibidor ou

enzima-substrato-inibidor

lactato desidrogenase

leucina para nitroanilida

metil beta glucosideo

peso molecular relativo

nonil beta glucosideo

octil beta glucosídeo

porcentagem de proteína

ponto isoelétrico

para nitro fenil beta

glucosídeo

substrato

succinato desidrogenase 
$\div \mathrm{U} / \div \mathrm{P}$

undecilßglu

V

Vmáx
Atividade específica

relativa

undecil beta glucosídeo

velocidade inicial

velocidade máxima 


\section{Considerações iniciais}

o estudo da digestão em insetos tem progredido nos últimos 15 anos graças a determinação da distribuição de enzimas nos vários compartimentos do tubo digestivo, à determinação da localização intracelular de enzimas digestivas e ao estudo das propriedades dessas enzimas (revisões em vonk \& Western, 1984, Applebaum, 1985, Terra, 1990 e Terra \& Ferreira, 1994).

A determinação da distribuição de enzimas nos vários compartimentos do canal alimentar permite esclarecer os passos pelos quais o alimento é hidrolisado nos diferentes sitios e auxilia a compreensão da atuação fisiológica de uma enzima.

A determinação da localização subcelular das enzimas digestivas também auxilia na compreensão das etapas pelas quais o alimento é hidrolisado. Há, por exemplo, enzimas digestivas que são encontradas somente adsorvidas ao glicocálix do epitélio intestinal e desse modo seu substrato provavelmente será clivado antes de ser absorvido pela célula. Além disso, o conhecimento da distribuição intracelular de enzimas digestivas auxilia na formulação de hipóteses sobre o mecanismo pelo qual uma determinada enzima está sendo secretada. Assim, uma enzima encontrada somente no citossol pode estar indo para o lúmen por secreção apócrina ou holócrina. Já se a enzima é encontrada em um sedimento onde ocorrem pequenas vesiculas e torna-se solúvel por ciclos de 
congelamento, o mais provável é que ela saia da célula por secreção do tipo merócrina.

o estudo das propriedades das enzimas digestivas permite-nos conhecer, por exemplo, em que região do tubo digestivo essas enzimas atuam e qual seu papel fisiológico, pois podemos determinar quais são seus substratos naturais, e se ela é responsável pela hidrólise de um composto ou de vários compostos relacionados entre si.

Esta dissertação é composta basicamente de duas partes. Uma delas vai tratar da distribuição subcelular de uma série de enzimas nas células do ceco anterior de $\underline{A}$. flavolineata, tentando determinar possíveis marcadores enzimáticos para os grânulos de secreção deste inseto. A outra parte tratará da separação e caracterização das $\beta$-glicosidases digestivas.

\section{1 - INTRODUÇÃO}

\subsection{Secreção de enzimas digestivas em insetos}

Um aspecto bastante polêmico na digestão dos insetos é o processo pelo qual as enzimas são secretadas pelo intestino médio (Chapman, 1985).

De um modo geral, os principais tipos de secreção são a merócrina (exocitose), apócrina e holócrina. Na secreção holócrina e apócrina, os produtos de secreção são armazenados no citoplasma da célula até serem liberados, quando então a célula inteira(secreção holócrina) ou parcialmente (secreção 
apócrina) é liberada para o lúmen. Na secreção merócrina (exocitose), os produtos de secreção estão compartimentados no interior de vesiculas, as quais fundem-se com a membrana plasmática para liberar seu conteúdo.Exocitose pode ser regulada ou constitutiva. $\mathrm{Na}$ exocitose regulada o produto a ser secretado é concentrado em vesículas de secreção (grânulos de armazenamento), as quais fundem-se a membrana plasmática somente quando a célula recebe um sinal apropriado (Palade, 1975). A exocitose constitutiva é observada em células responsáveis pela produção continua de proteínas e não ocorre acúmulo de grânulos no citoplasma (Willingham \& Pastan, 1984; Kelly, 1985).

A secreção holócrina em insetos é apenas descrita em niveis histológicos e ocorre naqueles animais que normalmente apresentam um grande número de células regenerativas em seu intestino médio. Esses insetos tem um período de vida relativamente grande e é provável que a renovação celular esteja sendo interpretada como secreção holócrina ( Terra \& Ferreira, 1994).

Extrusões celulares foram observadas no intestino médio de vários insetos e interpretadas muitas vezes como secreção apócrina (ver Terra \& Ferreira, 1994). Entretanto, Day \& Powning (1949) não conseguiram correlacionar a ocorrência dessas extrusões com um aumento das enzimas digestivas no lúmen. Além disso, Khan \& Ford (1962) observaram que as extrusões citoplasmáticas que aparecem em Dysdercus fasciatus 
(Hemiptera) aumentam quando o animal é submetido a jejum. Até o presente os resultados indicam que secreção apócrina não tem grande importância nos insetos. Apenas em stomoxys calcitrans (Diptera), onde a maioria da secreção se dá por via merócrina regulada (ver a seguir) parece haver extrusão apical de cerca de $30 \%$ dos grânulos de secreção (wood \& Lehane, 1991; Jordão, Ferreira, Lehane, manuscrito em preparação) .

Um modelo microapócrino para secreção de amilase e tripsina foi proposto no Lepidoptera Erinnyis ello (Santos et al, 1984, 1986). Segundo esse modelo, as enzimas estariam inicialmente ligadas à membrana de pequenas vesículas citoplasmáticas. Essas vesículas migrariam para as microvilosidades onde fundir-se-iam lateralmente brotando com dupla membrana. Alternativamente as vesículas podem fundir-se entre si e com o topo da microvilosidade destacando-se para - lúmen. No trajeto parte delas são solubilizadas e parte permanece ligada a membranas.

A maioria dos insetos não apresentam grandes quantidades de grânulos de secreção. Uma exceção é Stomoxys calcitrans (Diptera) cujos grânulos contém tripsina e talvez outras enzimas digestivas (Moffatt \& Lehane, 1990; Jordão, Ferreira, Lehane, manuscrito em preparação).

Como na maioria dos insetos é difícil observar grânulos de secreção nas células do intestino médio, eles devem secretar as enzimas digestivas de modo constitutivo. 
Apesar da pequena quantidade de grânulos de secreção que é observada no tubo digestivo da maioria dos insetos, alguns procedimentos bioquímicos tem evidenciado a secreção merócrina de algumas enzimas. Observando a distribuição das hidrolases após fracionamentos sub-celulares, Ferreira \& Terra (1989) e Ferreira et al. (1990) sugeriram que amilase, aminopeptidase e celobiase de Pheropsophus aequinoctialis e amilase, carboxipeptidase e tripsina de Tenebrio molitor estão presentes em grânulos de secreção.

Espinoza-Fuentes et al. (1987) trabalhando com Musca domestica e utilizando centrifugação diferencial obtiveram uma fração rica em algumas enzimas, que foi a seguir submetida a centrifugação isopícnica em gradiente de sacarose. Neste gradiente, amilase e lisozima eram recuperadas em uma posição intermediária. Quando a amostra a ser aplicada no gradiente era congelada e descongelada previamente essas atividades enzimáticas eram recuperadas no topo do gradiente, indicando que estavam acondicionadas em uma estrutura que rompeu-se com o congelamento, provavelmente uma vesícula de secreção.

Técnicas de imunocitolocalização também tem auxiliado os pesquisadores a desvendar os mecanismos de secreção apresentados pelos insetos. Assim, Lemos et al. (1993) comprovaram que a lisozima de Musca domestica (Diptera) ocorre em vesiculas de secreção. Jordão, Terra, Ribeiro, Lehane e Ferreira (manuscrito em preparação), utilizando anti-corpo contra tripsina 
solúvel de $\underline{M}$. domestica, mostraram que essa enzima ocorre inicialmente ligada a membrana dos grânulos de secreção e somente próximo a fase exocitica ela é solubilizada. Uma vez que essa enzima não apresenta zimógeno, os autores postulam que esse mecanismo daria uma proteção para as células em caso de rompimento acidental. Já stomoxys calcitrans (Diptera), que possui zimógeno para tripsina (Moffat \& Lehane, 1990), secreta essa enzima principalmente por via merócrina (mas as moléculas encontram-se sempre solúveis dentro do grânulo de secreção) (Jordão, Ferreira \& Lehane, manuscrito em preparação).

Atualmente há um número razoável de evidências da secreção merócrina de enzimas digestivas em insetos que apresentam secreção constitutiva. Entretanto, nunca obteve-se uma preparação de grânulos de secreção a partir do intestino desses animais. Nosso projeto inicial era isolar os grânulos de secreção presentes em Abracris flavolineata (Orthoptera), uma vez que uma inspeção preliminar por microscopia eletrônica mostrou uma quantidade razoável dessas estruturas nas células de seu intestino médio.

Já eram conhecidas quais as regiões do intestino responsáveis pela secreção de enzimas digestivas nesse animal (Ferreira et al, 1990b). Decidimos então determinar a distribuição subcelular dessas hidrolases na tentativa de definir os melhores marcadores enzimáticos para os grânulos de secreção, e obter frações ricas nessas organelas que seriam 
purificados posteriormente. Antes da realização do fracionamento subcelular, foi necessário verificar qual o melhor período para dissecar o animal. Isso porque sabe-se que gafanhotos sofrem variações fisiológicas em função de vários parâmetros, tais como luz e hora de alimentação (Chapman, 1990)

\subsection{Bglicosidases}

$\beta$ glicosidases catalizam a hidrólise de ligações $\beta$ 1-4 de resíduos de monossacarídeos do terminal não redutor de glicosideos.

Em inglês temos os termos " $\beta$-glucosidase" e " $\beta$ glycosidase". Estes 2 nomes permitem diferenciar entre enzimas que clivam ligações glicosídicas quaisquer ( $\beta$-glycosidase) daquelas enzimas que hidrolisam ligações glicosídicas onde $\circ$ monossacarídeo presente na extremidade não redutora é a glicose ( $\beta$-glucosidase). Grupos brasileiros que trabalham com carboidratos tem proposto que adote-se, em português, os termos ligação $\beta$-glicosídica ( e daí $\beta$-glicosidase) e ligação $\beta$-glucosídica ( e daí $\beta$ glucosidase) em analogia a língua inglesa. Nós utilizaremos esses termos ao longo do texto para maior clareza.

As $\beta$-glicosidases podem receber diferentes denominações dependendo do monossacarídeo que é removido. Por exemplo: $\beta$-glucosidase (monossacarídeo $=$ glicose), $\beta$-galactosidase (monossacarídeo= galactose), $\beta$-xilosidase ( monossacarídeo = xilose) $e$ assim por diante. Frequentemente, a mesma $\beta$ - 
glicosidase é capaz de hidrolisar vários resíduos de monossacarídeos diferentes, sendo nomeada de acordo com o substrato que ela hidrolisa com maior eficiência.

\subsection{1 $\beta$-glucosidases de mamíferos}

Três atividades de $\beta$-glucosidase tem sido descritas em mamíferos. Uma delas faz parte do complexo lactase-florizina hidrolase, ligada a membrana das microvilosidades intestinais. Essas duas atividades enzimáticas estão associadas a sítios ativos e domínios diferentes. Os dois sítios clivam $\beta$ -glucosideos e $\beta$-galactosídeos. O sítio da "lactase" prefere aglicones hidrofílicos, hidrolisando lactose e celobiose e o sítio da "florizina" prefere aglicones hidrofóbicos, hidrolisando florizina (um aril-glicosídeo) e também glucosil e galactosil ceramidas (Ver Wacker et. al., 1992; Semenza, 1986). Leese e Semenza (1973) comentam que esse complexo é eficiente na digestão do leite, uma vez que glucosil e galactosil ceramidas estão presentes nas membranas dos glóbulos de gordura do leite. Entretanto, não explica porque a florizina hidrolase (e não a lactase) ocorre, além de mamíferos, em todos os outros vertebrados (Semenza, 1986).

Freund et al. (1991) verificaram que a florizina hidrolase de rato é capaz de hidrolisar também laminaribiose e gentobiose. Esses dissacarídeos são derivados de $\beta$-glucanas de plantas, entre eles laminarina, o principal polissacarídeo de reserva de 
algas e importante constituinte da parede celular de fungos. Como lactose é restrita à dieta de mamíferos e glicosil-ceramidas estão presentes na dieta de todos os vertebrados, tem-se proposto que o gen para lactase-florizina hidrolase evoluiu de um gen que codificaria uma proteína com atividade de glicosilceramidase. Freund et al. (1991) propuseram que filogeneticamente a lactase-florizina hidrolase de mamiferos estaria relacionada à $\beta$-glucanase de invertebrados, sugerindo que $\circ$ gen ancestral da lactase-florizina hidrolase codificaria uma enzima envolvida na hidrólise de paredes celulares de fungos e plantas.

Vários orgãos de mamíferos (principalmente fígado $e$ rim) $e$ inclusive $o$ intestino, possuem uma $\beta$ glicosidase solúvel (Trumbo et al., 1990; Pócsi \& Kiss, 1989; Gopalan et al., 1992). Essa $\beta$-glicosidase apresenta ampla especificidade, podendo utilizar $\beta$ glucosídeos, $\beta$-xilosideos, $\beta$-galactosídeas e $\beta$ arabinosídeos como substrato (La Marco \& Glew, 1986). Gopalan et al. (1989), estudando essa enzima presente em fígado de porco, verificaram que álcoois primários em baixas concentrações são ativadores não essenciais, aumentando $\bigcirc$ Vmáx e não alterando $\bigcirc \mathrm{Km}$ dessa enzima. Em concentrações mais elevadas, a mesma substância age como inibidor competitivo. A enzima possui dois sítios distintos para ligação desses álcoois. Um sitio ativador com alta afinidade $e$ um sitio com baixa afinidade, que provavelmente faz parte do subsitio hidrofóbico do sitio ativo. 
A função fisiológica dessa enzima ainda permanece obscura. Mellor \& Layne (1971 e 1974) verificaram que essa enzima, originária de vários tecidos de mamíferos (inclusive intestino delgado), é capaz de hidrolisar glicosídeos esteroídicos e propuseram que uma de suas funções seria hidrolisar esses compostos produzidos endogenamente. Trumbo e colaboradores (1990) sugeriram que ela poderia estar envolvida na hidrólise de piridoxina 5 ' $\beta$-glucosídeo, que é uma forma da vitamina B6 normalmente encontrada em plantas. Mais recentemente, Gopalan e colaboradores (1992) mostraram que a glicosidase citossólica de fígado de cobaia é capaz de hidrolisar vários glicosídeos fenólicos e cianogênicos presentes em vegetais. Mostraram também que essas substâncias são absorvidas intactas pelo intestino e sugerem que a enzima poderia ser considerada como uma enzima envolvida em desintoxicação.

Tecidos de mamíferos possuem também uma $\beta$ glucosidase ligada a membrana dos lisossomos. Ela é altamente específica para substratos contendo glicose e hidrolisa glucocerebrosídeos e o glucolipídeo 2,3 ditetradecil $\beta$ glucosil glicerol (Glew et al, 1991). Além destes substratos, esta enzima também é ativa sobre aril $\beta$-glucosídeos e octil $\beta$-glucosídeo (Grabowski \& Dagan, 1984) Esta enzima é ativada por lipídeos carregados negativamente como taurocolato e fosfatidilserina, possuindo um sítio para ligação destes compostos distinto do sítio ativo (Grabowski et al., 1984). Osiecki-Newman (1987) propuseram um 
modelo para o sítio ativo desta enzima, composto por um subsitio para ligação do glicone e um subsítio hidrofóbico para ligação do aglicone. Aparentemente, a enzima citossólica comentada anteriormente possui no seu sítio ativo um subsitio muito mais hidrofóbico do que o subsítio presente no sítio ativo da glucocerebrosidase lisossômica, pois Gopalan et al. (1987) trabalhando com a $\beta$-glicosidase citossólica de fígado humano e a glucocerebrosidase lisossômica de placenta humana determinaram a constante de inibição (Ki) dessas enzimas por uma série de alquil $\beta$-glucosideos. As constantes de inibição obtidas com a enzima citossólica são muito menores (cerca de 100 a 250 vezes) que aquelas obtidas com a enzima lisossomal, o que os levou a concluir que em relação a glucocerebrosidase lisossomal, a $\beta$-glicosidase citossólica possuía um subsitio mais hidrofóbico em seu sítio ativo.

Mais recentemente uma glucocerebrosidase não lisossômica foi demonstrada em vários tecidos humanos. Através da análise de fracionamentos subcelulares verificou-se que ela ocorre em um compartimento celular de baixa densidade. Esta enzima, ao contrário da glucocerebrosidase lisossômica, é fortemente associada a membrana. Esta glucocerebrosidase não lisossomal mostrou-se menos sensivel a inibição por castanospermina e deoxinojirimicina, porém mais sensível a inibição por glucono $\delta$-lactona que a glucocerebrosidase lisossomal. Além disso taurocolato, um ativador da 
glucocerebrosidase lisossômica, é um bom inibidor para a enzima não lisossomal (van weely et al, 1993).

\subsection{2 $\beta$-glicosidases de insetos}

Em insetos há poucos trabalhos sobre $\beta$ glicosidases. Além disso, em muitos deles não podemos inferir a especificidade das enzimas porque os ensaios foram feitos somente com um substrato (por exemplo:MC Even et al., 1980; Groover et al., 1988) ou vários substratos foram usados alternadamente (por exemplo:Ito \& Tanaka, 1959). Outras vezes, os trabalhos apresentam uma Iista de substratos que são hidrolisados pelo tubo digestivo do animal, mas não fica claro quantas enzimas estão envolvidas (por exemplo: Yu, 1989).

Devido a pouca disponibilidade de dados na literatura e as dúvidas que ainda pairam a respeito do número e especificidade das $\beta$-glicosidases encontradas num determinado inseto a função dessas enzimas ainda não é totalmente clara.

A função das enzimas muito ativas sobre celobiose foi obscura por muito tempo, uma vez que vários insetos que possuiam alta atividade dessa enzima não eram capazes de hidrolisar celulose. Após verificarse a ampla especificidade dessas enzimas em Rhynchosciara americana (Diptera) (Ferreira \& Terra, 1983) e em Erynnyis ello (Lepidoptera) (Santos \& Terra, 1985) e a capacidade que os insetos tem de digerir hemiceluloses (Terra et al., 1987), sua função 
ficou mais clara. Provavelmente elas auxiliam a digestão final de celulose e hemiceluloses.

$\beta$-glicosidases que só hidrolisam substratos sintéticos ainda não tiveram sua função comprovada, embora Terra \& Ferreira (1994) tenham formulado a hipótese de que elas podem agir sobre glico e/ou galactolipideos de membrana (ver a seguir).

Baseando-se nas informações disponíveis na literatura, Terra \& Ferreira (1994) propuseram um sistema de classificaçào para as $\beta$-glicosidases de insetos com base na especificidade das mesmas pelo substrato.

A classe 1 corresponderia às enzimas que possuem atividade de glicosil $\beta$-glicosidase e aril $\beta$ glicosidase, isto é, enzimas ativas sobre dissacarídeos naturais, tais como celobiose e lactose e p-nitrofenilglicosideos, como $p N \phi \beta g l u, p N \phi \beta g a l$ e $p N$ $\phi \beta$ fuc. Na classe 2 encontraríamos enzimas com função exclusiva de glicosil $\beta$-glicosidase, hidrolisando com eficiência somente substratos como celobiose e lactose, enquanto na classe 3 teríamos enzimas com atividade de aril e/ou alquil $\beta$-glicosidases, que são as que só exibem atividade significativa sobre pN $\phi \beta$ glu e substratos similares.

Dentro da classe 1 (enzimas com atividade aril e glicosil $\quad \beta$-glicosidásical encontramos $2 \beta$ glicosidases bem caracterizadas. São a $\beta$-glicosidase de Rhynchoschiara americana (Eerreira \& Terra, 1983) e a de Erinnyis ello (Santos \& Terra, 1985). 
A Bglicosidase de $\underline{R}$. americana é uma enzima ligada a membrana plasmática das células do intestino médio das larvas desse inseto. A enzima pode ser solubilizada através de tratamento com Triton X-100 ou com papaína. A forma solubilizada com detergente apresenta um Mr maior (106.000) que a forma solubilizada proteoliticamente $(\mathrm{Mr}=65.000)$, o que sugere a existência de um segmento hidrofóbico para inserção na membrana. Esta $\beta$-glicosidase hidrolisa uma série de p-nitrofenilglicosídeos ( $\beta$-glucosídeos, $\beta$-galactosídeo e $\beta$-fucosídeo), além de celobiose, sendo que a hidrólise ocorre sem inversão da configuração da glicose e é fortemente inibida por glicono $\delta$-lactona $(\mathrm{Ki}=0,5 \mu \mathrm{M})$. Estes dados sugerem que a hidrólise envolve a formação de um ion carbonium como intermediário (Ferreira \& Terra, 1983).

A Bglicosidase de E. ello é uma enzima solúvel do intestino médio das larvas desse inseto. Esta enzima hidrolisa celobiose e p-nitrofenilglicosideos ( $\beta$ glucosídeos, $\beta$-galactosídeo e $\beta$-fucosídeos) no mesmo sítio ativo (inferido a partir de experimentos de inativação térmica e competição entre substratos). Esta $\beta$-glicosidase é fortemente inibida por glicono $\delta$ - Iactona $(\mathrm{Ki}=0,85 \mu \mathrm{M})$ e a hidrólise ocorre sem inversão da configuração da glicose liberada, sugerindo o mesmo mecanismo que da $\beta$-glicosidase de R. americana (Diptera) (Santos \& Terra, 1985).

Outros exemplos de $\beta$-glicosidase da classe 1 são encontrados nas larvas dos Coleoptera Rhagium 
inquisitor (Chipoulet \& Chararas, 1985) e Phoracantha semipunctata (Chararas \& Chipoulet, 1982). As $\beta$ glicosidases encontradas nestes insetos hidrolisam celobiose, fenil $\beta$-D-glucosídeo, p-nitrofenil $\beta$ glucosídeo e salicina. Entretanto, não foi verificado se estes substratos são hidrolisados no mesmo sítio ativo. Tanto R. inguisitor como $\underline{\mathrm{P} \text {. semipunctata são }}$ insetos que no estágio larval vivem em madeira em decomposição, portanto devem ter em sua dieta $\beta$ glicosideos derivados da digestão de celulose e hemicelulose. Assim é possível que o papel fisiológico destas $\beta$-glicosidases seja realizar a digestão final destes $\beta$-glicosídeos. $\underline{R \text { americana }}$ (Diptera) também alimenta-se em seu estágio larval de material vegetal em decomposição, estando presente em sua dieta celulose e hemicelulose. Deve-se ressaltar que $\underline{R}$. americana apresenta atividade celulásica em seu intestino médio (Terra et. al, 1979), tornando provável que a $\beta$-glicosidase também atue na digestão final de celulose. Já E. ello (Lepidoptera) alimentase de folhas de Euphorbiaceae (mandioca, por exemplo), sendo capaz de utilizar as hemiceluloses presentes nesta dieta (Terra et al., 1987), e sua $\beta$ glicosidase deve atuar na digestão final desses compostos.

Quanto as $\beta$-glicosidases da classe 2 , ou seja, enzimas que apresentam apenas atividade de glicosil $\beta$ -glicosidase, podemos encontrá-las em Locusta migratoria (Orthoptera) (Morgan, 1975) e Sitophilus oryzae (Coleoptera) (Baker \& Woo, 1992). 
A $\beta$-glicosidase de classe 2 encontrada em $\underline{S}$. oryzae hidrolisa preferencialmente celobiose, e embora também hidrolise pNфßglu, amigdalina e helicina, a relação Vmáx/Km é cerca de oito vezes maior para a celobiose (Baker \& Woo, 1992). Em L. migratoria, Morgan (1975) demonstrou que no intestino médio deste gafanhoto ocorre uma $\beta$-glicosidase que hidrolisa exclusivamente celobiose e lactose. Esta enzima é inibida de modo competitivo por glicono $\delta$ lactona, sendo que obtém-se o mesmo valor de $\mathrm{ki}$ com ambos substratos, indicando que tanto celobiose como lactose são hidrolisados no mesmo sítio ativo.

$\beta$-glicosidase de classe 3 (atividade de aril e/ou alquil $\beta$-glicosidase) ocorre, por exemplo, em Sitophilus oryzae (Coleoptera) (Baker \& Woo, 1992), Locusta migratoria (Orthoptera) (Morgan, 1975), Thaumetopoea pityocampa (Lepidoptera) (Pratviel-Sosa et. al., 1987), Calliphora erythrocephala (Evan, 1956) e Diathraea saccharalis (Diptera)(Ferreira, Torres \& Terra, resultados não publicados). No caso de L. migratoria (Morgan, 1975) a $\beta$-glicosidase de

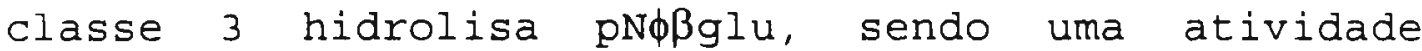
enzimática distinta da atividade sobre pN $\phi \beta g a l$,

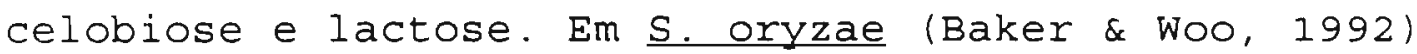
a Bglicosidase classe 3 hidrolisa preferencialmente helicina, amigdalina e pNфßglu, sendo que a relação Vmax/Km é cerca de 10 vezes maior para helicina em relação a celobiose. Já em T. pityocampa encontramos uma $\beta$-glicosidase muito ativa sobre pN $\phi \beta g l u$, coniferina, betulosídeo, salicina, arbutina e 
laminaribiose, porém pouco ativa sobre celobiose. A atividade sobre aril $\beta$-glicosideo é cerca de 40 vezes maior que sobre celobiose (Pratviel-sosa et.al., 1987).

Por muito tempo a função das enzimas pertencentes a classe 3 permaneceu inexplicada e nenhuma hipótese foi aventada sobre seu possível papel fisiológico, uma vez que, na maioria dos casos só era detectada atividade dessas enzimas sobre substratos sintéticos. As primeiras hipóteses sobre a função dessas enzimas foram levantadas por Terra \& Ferreira (1994). Esses autores postularam que uma vez que as $\beta$-glicosidases pertencentes a classe 3 hidrolisam monossacarídeos ligados a aglicones hidrofóbicos é provável que seus substratos naturais sejam glicolipideos, tais como glucosilceramidas. Uma evidência nessa direção é o fato da $\beta$-glicosidase de Thaumetopopoea pityocampa hidrolisar, além de outros glicosídeos, laminaribiose (Pratviel-sosa et.al., 1987). Conforme comentado anteriormente, esse mesmo comportamento foi observado para a glucosilceramidase de mamiferos (Freund et.al., 1991). Essa classe de enzimas poderia também hidrolisar monoglucosildiglicerídeos, que são glucolipídeos de muitas plantas (Quinn \& Williams, 1983). Para hidrolisar os aril e alquil-glicosideos, que são substratos conhecidos dessas enzimas, e as glucosilceramidas e monoglucosilglicerídeos que são seus hipotéticos substratos naturais, essas enzimas devem ter um sítio ativo com uma região hidrofóbica. Essa característica possibilitaria a elas também 
hidrolisar glicosideos que naturalmente ocorrem em plantas e cujo aglicone é hidrofóbico e muitas vezes tóxico (ver abaixo).

A especificidade ao substrato das $\beta$-glicosidases da classe 1 é uma combinação daquela apresentada pelas enzimas da classe 2 e 3 . Insetos que não possuem $\beta$-glicosidases da classe 1 aparentemente apresentam 2 enzimas diferentes, uma pertencente à classe 2 e outra à classe 3 . Isso é observado em Locusta miqratoria (Morgan, 1975) e Sitophilus oryzae (Baker \& Woo, 1992). Essa condição de possuir uma ou duas $\beta$-glicosidases foi interpretada por Terra \& Ferreira (1994) como uma adaptação dos ancestrais de diferentes grupos a certas dietas vegetais. Algumas plantas contém glicosídeos potencialmente tóxicos. Nesses glicosídeos o aglicone é hidrofóbico e ligado por uma ligação $\beta$-glicosídica a um monossacarídeo. Assim, podem ser hidrolisados por $\beta$-glucosidases que possuem sítios ativos hidrofóbicos. Como os aglicones são mais tóxicos que os glicosídeos (Yu, 1989), a intoxicação pode ser evitada diminuindo a quantidade da $\beta$-glicosidase adequada. Se o inseto possui os 2 tipos de atividade em enzimas diferentes, é possível diminuir a síntese da glicosilceramidase sem prejudicar a digestão terminal de celulose e hemiceluloses.

Os experimentos de Lindroth (1988) favorecem esta hipótese. Lindroth (1988) demonstrou que Papilio glaucus canadensis (Lepidoptera), o qual é adaptado à dieta com glicosídeos fenólicos, apresenta a 
atividade de $\beta$-glicosidase reduzida a cerca de $1 / 3$ da atividade de $\beta$-glicosidase de Papilio glaucus glaucus (Lepidoptera), o qual não é adaptado a presença de $\beta$ glicosídeos fenólicos. Além disso a ingestão de glicosídeos fenólicos por 2 dias antes da dissecção suprimiu a atividade de $\beta$-glicosidase em p.g.canadensis, mas em p.g.glaucus a atividade foi induzida.

Estes resultados indicam um possível mecanismo de defesa do inseto contra glicosideos tóxicos baseado na supressão da atividade de $\beta$-glicosidases. Porém não foi verificado se as duas subespécies de p.glaucus apresentavam diferenças quanto ao número $e$ especificidade das $\beta$-glicosidases.

Para elucidar $\circ$ papel fisiológico das $\beta$ glicosidases digestivas em insetos, assim como aumentar o conhecimento sobre sua enzimologia, seria interessante separar e caracterizar essas enzimas a partir de vários insetos com hábitos alimentares diferentes.

Resultados preliminares mostraram que Abracris flavolineata (Orthoptera) possuia 2 ou $3 \beta$ glicosidases. A. flavolineata é um gafanhoto polífago (Chapman, 1990) e pode encontrar glicosídeos tóxicos em sua dieta. Ferreira et al (1992) verificaram que A. Elavolineata digere celulose e talvez hemicelulose. Esse inseto possui em seu intestino médio uma série de enzimas solúveis responsáveis pela digestão destes polissacarídeos (sistema celulásico completo, laminarinase, xilanase, mananase e 
pectinase - resultados não publicados). Estas enzimas provavelmente são responsáveis pela formação de uma série de $\beta$-glicosideos que são potenciais substratos para $\beta$-glicosidases da classe 1 e 2 . Sendo herbívoro na dieta de $\underline{A}$. flavolineata também ocorrem glicolipídeos de membranas vegetais lQuinn \& Willians, 1983), potenciais substratos da $\beta$ glicosidase de classe 3. Abracris flavolineata foi escolhido para iniciar o estudo das $\beta$-glicosidases em insetos principalmente pela indicação de possuir várias dessas enzimas. 


\section{2-Materiais e Métodos}

\subsection{Materiais biológico}

Para dissecção foram utilizados machos adultos de A. Elavolineata (Orthoptera - Acrididae) em idade de acasalamento. Os animais foram criados em nosso laboratório em gaiolas mantidas em condições controladas de temperatura $\left(25^{\circ} \mathrm{C}\right)$ e luminosidade natural. A estes gafanhotos eram fornecidas à vontade folhas de couve (Brassica olearacea acephala) frescas, lavadas e originárias de cultivo sem agrotóxicos. Foram escolhidos os machos, pois apesar de menores, não sofriam a influência do ciclo reprodutivo na alimentação. Em fêmeas, o padrão de alimentação é alterado em função do ciclo reprodutor (Simpson, 1990). Além disso, as fêmeas ficariam preservadas para a postura de ovos. Para a coleta de regurgitado utilizou-se machos e fêmeas.

\subsection{Coleta de regurgitado}

Abracris flavolineata sob pressão abdominal regurgita um líquido denso e rico em enzimas digestivas. Este material é coletado com auxilio de micropipetador $(5 \mu l)$ e armazenado em tubos de ensaio a $-15{ }^{\circ} \mathrm{C}$. Em cada coleta que, pode ser repetida com um intervalo de 7 dias, obtém-se aproximadamente $5 \mu \mathrm{l}$ de material/inseto.

\subsection{Dissecção de adultos de A. flavolineata}


Para obtenção de amostras de tubo digestivo para

sua utilização como fonte de enzimas, gafanhotos imobilizados em gelo eram dissecados sob lupa em solução gelada de $\mathrm{NaCl} 250 \mathrm{mM}$. O tubo digestivo completo era retirado, sendo separado da maioria dos túbulos de Malpighi e das grandes traquéias.

Os cecos anteriores eram separados do restante do tubo digestivo, seu conteúdo retirado através de punção com capilar de vidro e tecido lavado com solução gelada de $\mathrm{NaCl} 250 \mathrm{mM}$. Os cecos anterios foram escolhidos pois o tubo digestivo de $\underline{A}$. flavolineata apresenta, segundo ferreira et al. (1990), 3 regiões que são capazes de secretar enzimas digestivas: os cecos anteriores, os cecos posteriores e 0 ventrículo. Estas 3 regiões apresentam praticamente a mesma atividade específica para várias enzimas digestivas. De acordo com eletroferogramas, as enzimas que ocorrem nestes 3 compartimentos são idênticas. Assim, como os cecos anteriores são a maior das regiões referidas, ao menos quantitativamente eles seriam os principais responsáveis pela secreção de enzimas digestivas.

\subsection{Homogeneização dos cecos anteriores de $\underline{\text { A. }}$} flavolineata

O epitélio dos cecos anteriores foi homogeneizado em homogeneizadores do tipo Potter-Elvehjem com um total de 10 movimentos do pistilo em meio contendo manitol $471 \mathrm{mM}$ e fosfato dibásico de sódio $2 \mathrm{mM}$ com $\mathrm{pH}$ acertado para 7,0 . O homogeneizado era 
posteriormente filtrado em tela de nylon de $45 \mu \mathrm{m}$ e 0 volume acertado em proveta de modo a conter cecos anteriores de 1,0 animal/ml.

\subsection{Obtenção de frações com enzimas solūveis e} particuladas a partir dos cecos anteriores de $\underline{A}$. flavolineata em diferentes tempos após a refeição.

Adultos de $\underline{A}$. flavolineata receberam apenas água por 24 horas. Terminado esse período faziam uma refeição iniciada às 12 horas, com duração de 20 minutos, durante a qual comiam à vontade. O período de refeição era contado a partir do início da ingestão e eventuais intervalos não eram descontados. Após essa refeição eram novamente privados de comida por intervalos de tempo diferentes $(0,1,3$ e 5 horas), quando eram dissecados e os cecos anteriores coletados e homogeneizados. Para cada intervalo de tempo após a refeição, eram preparados 2 grupos com 2 individuos cada.

o homogeneizado dos cecos anteriores era a seguir centrifugado a $100.000 \mathrm{xg}$ por 60 minutos. 0 sobrenadante foi denominado $s$ e guardado para determinações posteriores. O precipitado resultante foi ressuspenso no meio de homogeneização, congelado e descongelado 3 vezes e recentrifugado a $100.000 \mathrm{xg}$ por 60 minutos, originando outro sobrenadante (SM) e um precipitado (PM). As atividades enzimáticas obtidas nas 3 frações subcelulares (, , SM e PM) são somadas e a porcentagem de atividade presente em cada fração é calculada em relação a soma. o mesmo foi 
feito para massa de proteínas. Os dados são apresentados em figuras construidas plotando-se a atividade especifica relativa (\%de atividade/\% de proteína) versus a porcentagem de proteína . Cada fração é representada por um paralelogramo cuja área é proporcional à atividade recuperada naquela fração e a altura corresponde a purificação obtida (De Duve et al., 1955).

\subsection{Centrifugação diferencial do homogeneizado dos} cecos anteriores de A.flavolineata

Homogeneizados dos cecos anteriores obtidos como descrito anteriormente foram centrifugados à $4^{\circ} \mathrm{C}$ e as frações seguintes foram coletadas: P1, sedimento 600 xg 10 minutos; P2, sedimento $3.000 \mathrm{xg} 10$ minutos; P3, sedimento $17.000 \mathrm{xg} 10$ minutos; P4, sedimento 100.000 $\mathrm{xg} 60$ minutos e SF, sobrenadante $100.000 \mathrm{xg} 60$ minutos. As frações sedimentadas (P1, P2, P3 e P4) foram ressuspensas e homogeneizadas em PotterElvejhen no meio de homogeneização inicial. Após serem congeladas e descongeladas 3 vezes foram centrifugadas a $100.000 \mathrm{xg}$ por 60 minutos. Os sobrenadantes e os sedimentos correspondentes a cada fração foram utilizados para ensaios enzimáticos e determinação de proteínas. A figura 1 apresenta este procedimento resumidamente.

Em outra série de experimentos, as centrifugações a $100.000 \mathrm{xg}$ foram realizadas por 3 horas ao invés de 1 hora como citado anteriormente. 


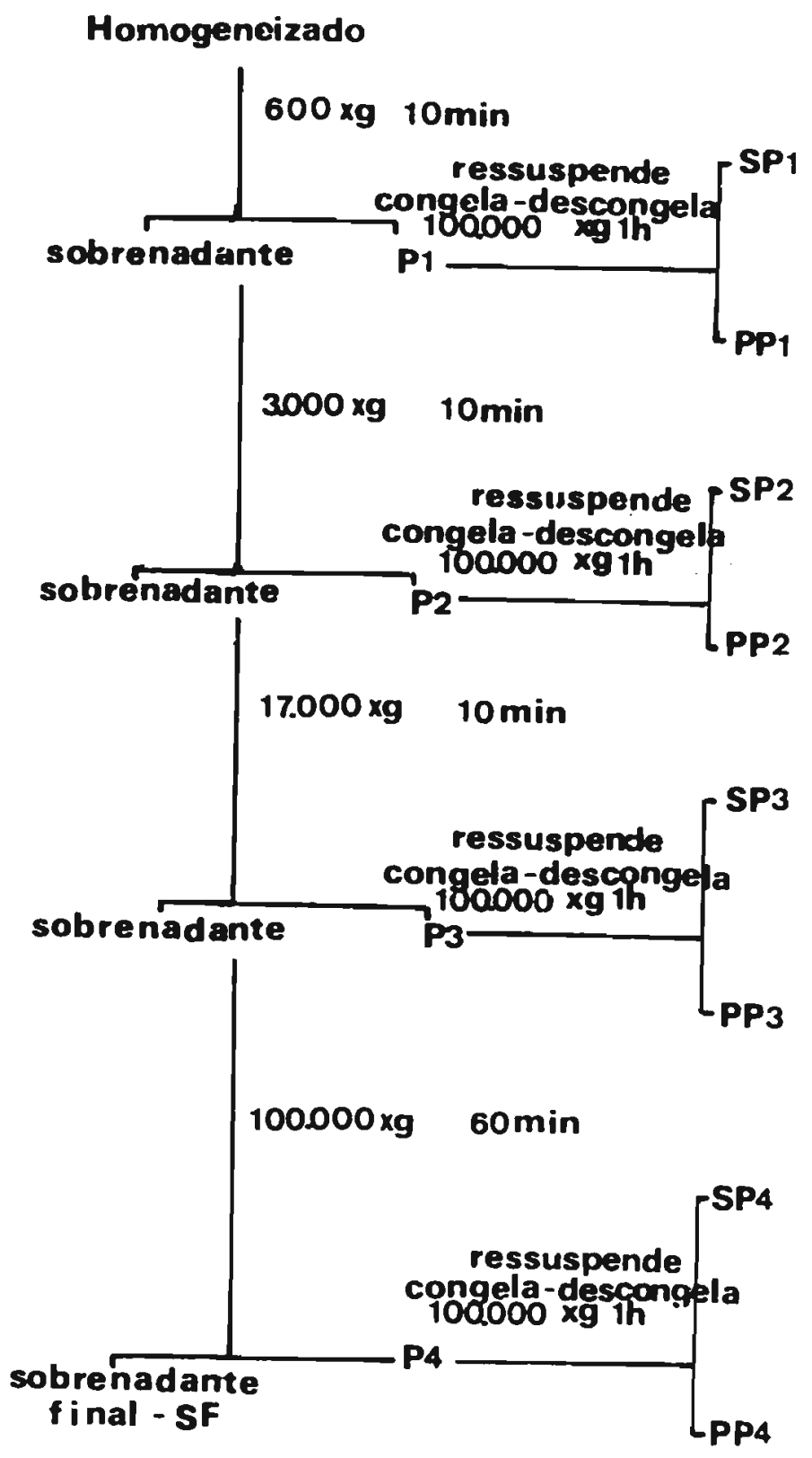

Figura 1 - Fluxograma da centrifugação diferencial do homogeneizado dos cecos anteriores de A. flavolineata para obtenção das Erações subcelulares. 
Os resultados obtidos foram apresentados na forma de figuras construídas segundo De Duve et. al. (1955), de forma análoga ao descrito em 2.5 .

\subsection{Ensaios enzimáticos e determinação de proteínas}

A detecção da atividade enzimática foi realizada incubando-se a mistura de reação em banho-maria termostatizado $\left(30^{\circ} \mathrm{C}\right)$ por diferentes períodos de tempo. Controles sem enzima (brancos de substrato) e sem substrato (branco de enzima) foram incubados do mesmo modo que os experimentais. A atividade observada foi expressa em nmoles de substrato ou ligação hidrolisado por minuto (mU, miliunidades)

A tabela 1 resume os substratos, tampões usados e os produtos determinados para cada tipo de ensaio enzimático.

A massa de proteínas foi determinada utilizandose Comassie blue $G$ segundo Bradford (1976), no caso dos fracionamentos subcelulares e com ácido bicinchonínico segundo Morton \& Evans (1992), no caso da purificação das $\beta$-glicosidases. Em ambos casos foi usada albumina de ovo como padrão. Para Comassie blue G, albumina sérica bovina não é bom padrão, pois é capaz de ligar mais corante que a maioria das proteínas (Read \& Northcote, 1984).

2.8 Cromatografia em coluna de Superose 12 usando sistema de FPLC

Amostras de $200 \mu \mathrm{l}$ de regurgitado de $\underline{A}$. Elavolineata diluídas $5 x$ em água bi-destilada e 
Tabela 1 - Condições de ensaio padrão e métodos usados na determinação de atividades enzimáticas *.

\begin{tabular}{|c|c|c|c|c|c|}
\hline Enzima & Substrato & $\mathrm{pH}$ & $\begin{array}{l}\text { Conceñ } \\
\text { tração }\end{array}$ & $\begin{array}{l}\text { Substância } \\
\text { ou grupo } \\
\text { determinado }\end{array}$ & Referência \\
\hline amilase & amido** & 6,5 & $0,5 \div$ & $\begin{array}{l}\text { grupos } \\
\text { redutores }\end{array}$ & $\begin{array}{c}\text { Noelting \& } \\
\text { Bernfeld (1948) }\end{array}$ \\
\hline aminopeptidase & Lpna & 8,0 & $1 \mathrm{mM}$ & $\frac{\mathrm{p}^{-}}{\text {nitroanilida }}$ & $\begin{array}{c}\text { Erlanger et.al. } \\
(1961)\end{array}$ \\
\hline dipeptidase & Gly-Leu & 8,0 & $5 \mathrm{mM}$ & Leucina & $\begin{array}{c}\text { Nicholson \& } \mathrm{Kim} \\
(1975)\end{array}$ \\
\hline$\beta g l$ icosidase & celobiose & 6,0 & $7 \mathrm{mM}$ & glicose & Dahlquist (1968) \\
\hline$\beta g l i c o s i d a s e$ & $\mathrm{pN} \phi \beta g l u$ & 6,0 & $1 \mathrm{mM}$ & $\frac{\mathrm{p}-}{\text { nitrofenolato }}$ & $\begin{array}{c}\text { Terra et.al. } \\
(1979)\end{array}$ \\
\hline$\beta g l i c o s i d a s e$ & $\begin{array}{c}\text { alquil } \beta g l u \\
(1 \text { e } 6 \text { a } 11 \mathrm{c})\end{array}$ & 6,0 & $0,5 \mathrm{mM}$ & glicose & Dahlquist (1968) \\
\hline$\beta g l i c o s i d a s e$ & salicina & 6,0 & $5 \mathrm{mM}$ & glicose & Dahlquist (1968) \\
\hline Bglicosidase & arbutina & 6,0 & $5 \mathrm{mM}$ & glicose & Dahlquist (1968) \\
\hline$\beta g l i c o s i d a s e$ & Iaminaribiose & 6,0 & $7 \mathrm{mM}$ & glicose & Dahlquist (1968) \\
\hline $\begin{array}{l}\text { yglutamil } \\
\text { transferase }\end{array}$ & $\begin{array}{l}\text { glutamil p- } \\
\text { nitroanilida e } \\
\text { glicil-glicina }\end{array}$ & 8,8 & $\begin{array}{c}1 \mathrm{mM} \\
\mathrm{e}^{-} \\
50^{\mathrm{mM}}\end{array}$ & $\frac{p-}{\text { nitroanilida }}$ & $\begin{array}{c}\text { Erlanger et al. } \\
\text { (196I) }\end{array}$ \\
\hline LDH & $\begin{array}{l}\text { Iactato de } \\
\text { sódio }\end{array}$ & 7,4 & $50 \mathrm{mM}$ & formazan & $\begin{array}{l}\text { Bergmeyer } \& \\
\text { Bernt }(1974)\end{array}$ \\
\hline maltase & maltose & 6,0 & $7 \mathrm{mM}$ & glicose & Dahlqvist (1968) \\
\hline $\mathrm{SDH}$ & $\begin{array}{c}\text { succinato de } \\
\text { sódio }\end{array}$ & 7,5 & $20 \mathrm{mM}$ & formazan & $\begin{array}{c}\text { Santos \& Terra } \\
(1984)\end{array}$ \\
\hline tripsina & BAPA & 7,5 & $0,8 \mathrm{mM}$ & $\frac{p^{-}}{\text {nitroanilida }}$ & $\begin{array}{c}\text { Exlanger et.al } \\
(1961)\end{array}$ \\
\hline
\end{tabular}

* Os tampões utilizados na concentração final de $50 \mathrm{mM}$. Foram usados: citrato fosfato ( $\mathrm{pH} 6,0$ e 6,5), fosfato ( $\mathrm{pH} 7,5$ e 8,0 no caso da aminopeptidase), Tris ( $\mathrm{pH}$ 8,0 no caso da dipeptidase), Tris (pH 8,8 no caso da $\gamma$ glutamil transferase). Diferenças no ensaio enzimático será indicado.

* No substrato foi acrescentado $\mathrm{NaCl}$ para concentração final 0,01 $\mathrm{M}$. 
contendo aproximadamente $6,0 \mathrm{mg}$ de proteína foram aplicadas em uma coluna de superose 12 em sistema FPLC (Pharmacia - LKB Biotechnology, Suécia) e eluída com um fluxo de $0,4 \mathrm{ml} / \mathrm{min}$ de um tampão citrato fosfato $100 \mathrm{mM}$ pH 6,0 preparado em água milliq e desaerado. O eluído foi coletado em frações de $200 \mu 1$ que serviram como fonte de material para ensaios enzimáticos. Também foram realizadas eluições na presença de Triton $\mathrm{X}-100$ e para isto o detergente foi adicionado ao tampão para concentração final de $0,3 \%$ ou $0,0135 \%(\mathrm{p} / \mathrm{v})$, respectivamente 20 e $0,9 \mathrm{CMC}$.

\subsection{Passagem do material coletado de Superose $12 \mathrm{em}$ coluna de Fast Desalting}

Um volume de $2 \mathrm{ml}$ do conjunto de frações que

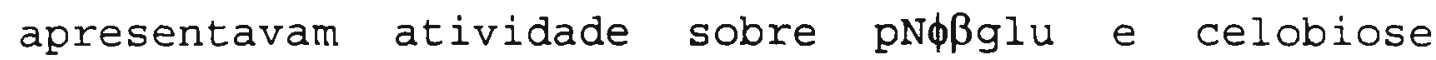
coletadas da coluna de Superose 12 contendo $1,6 \mathrm{mg}$ de proteína foi aplicado a uma coluna de Fast Desalting (sistema FPLC). Conforme o tipo de coluna em que a amostra seria aplicada a seguir a eluição (3 $\mathrm{ml} / \mathrm{min}$ ) foi feita com um dos tampões: trietanolamina $10 \mathrm{~mm} \mathrm{pH}$ 8,0, pH 8,5 e pH 7,5, imidazol $20 \mathrm{mM} \mathrm{pH} \mathrm{6,2} \mathrm{e} \mathrm{citrato}$ fosfato $20 \mathrm{mM} \mathrm{pH} \mathrm{5,5.} \mathrm{Todos} \mathrm{foram} \mathrm{preparados} \mathrm{com} \mathrm{água}$ milliQ e desaerados.

- eluído foi coletado em frações de $400 \mu l$ e serviu como fonte de material para ensaio enzimático.

\subsection{Cromatografia em coluna de troca iônica Mono Q usando sistema de FPLC.}


As frações coletadas da coluna de Fast Desalting que apresentavam atividade sobre pN $\phi \beta g l u$ e celobiose foram reunidas e $2 \mathrm{ml}$ desta amostra foram aplicados a uma coluna de Mono Q HR $5 / 5$ equilibrada com o mesmo tampão em que se encontrava a amostra (ver a seguir). Após lavagem da coluna com $5 \mathrm{ml}$ desse tampão para retirar o material não ligado a coluna, passou-se um gradiente de $20 \mathrm{ml}$ de $\mathrm{NaCl}$ dissolvido no mesmo tampão. Os tampões empregados foram trietanolamina 10 $\mathrm{mM} \mathrm{pH} 8,0, \mathrm{pH} 8,5$ e $\mathrm{pH} 7,5$ e imidazol $20 \mathrm{mM} \mathrm{pH} 6,2$. Os tipos de tampão e o perfil do gradiente de $\mathrm{NaCl}$ encontram-se indicados nas figuras. Os tampões foram preparados em $\mathrm{H}_{2} \mathrm{O}$ milliQ e desaerados. Foram coletadas frações de $400 \mu l$ que serviram como material para ensaios enzimáticos.

\subsection{Cromatografia em coluna de troca iônica Mono S} usando sistema de FPLC.

As frações coletadas da coluna Fast Desalting com tampão citrato fosfato $20 \mathrm{mM} \mathrm{pH} \mathrm{5,5,} \mathrm{que} \mathrm{apresentavam}$ atividade sobre pN $\phi \beta g l u$ e celobiose foram reunidas e aplicadas em uma coluna Mono $S$ HR $5 / 5$ equilibrada com tampão citrato fosfato $20 \mathrm{mM}$ pH 5,5. Após lavagem da coluna com $5 \mathrm{ml}$ desse tampão para retirar o material não Iigado a coluna, passou-se um gradiente linear de $\mathrm{NaCl}$ em tampão com volume de $20 \mathrm{ml}$ e com concentração inicial de $0,1 \mathrm{M}$ e final de $1 \mathrm{M}$. Coletou-se frações de $400 \mathrm{\mu l}$ que foram utilizadas como material para ensaios enzimáticos. 


\subsection{Cromatografia hidrofóbica em coluna de Alquil- Superose usando sistema de FPLC.}

As frações coletadas da coluna Fast Desalting com tampão citrato fosfato $20 \mathrm{mM}$ pH 5,5, que apresentavam atividade sobre pN $\phi \beta g l u$ e celobiose foram reunidas e aplicadas em uma coluna Alquil-Superose. Após aplicação da amostra, aguardava-se 20 minutos para então lavar-se a coluna com $5 \mathrm{ml}$ do mesmo tampão descrito acima e eluiu-se com um gradiente linear de etilenoglicol de 0 a $25 \%(\mathrm{v} / \mathrm{v})$ no tampão inicial.

O material eluído foi coletado em frações de 400 $\mu l$ e utilizado para ensaios enzimáticos.

\subsection{Cromatografia hidrofóbica em coluna de Octil-} Sepharose

As frações eluídas da coluna de superose 12 com tampão citrato fosfato $20 \mathrm{mM} \mathrm{pH} 6,0$ que apresentavam atividade sobre pN $\phi \beta g l u$ foram reunidas e aplicadas em coluna de octil-Sepharose. Após a aplicação da amostra aguardava-se 45 minutos para então lavar-se a coluna com $40 \mathrm{ml}$ do tampão citrato fosfato $20 \mathrm{~mm} \mathrm{pH}$ 6,0. Em seguida a coluna era eluída com uma solução de etilenoglicol $80 \%(\mathrm{v} / \mathrm{v})$ no tampão inicial. material eluído foi coletado em frações de $400 \mu l$ e utilizado para ensaios enzimáticos.

\subsection{Eletroforese em cilindros de poliacrilamida}

Após eluição da coluna de Mono Q com tampão trietanolamina pH 8,0 , obtem-se 2 picos de atividade enzimática sobre pN $\phi \beta g l u$. A partir do eluído de Mono 
Q, as seguintes frações foram reunidas: frações 18 a 21 (formando o material Q1) e frações 30 a 34 (formando o material Q2). O material Q1 é também ativo sobre celobiose e o material Q2 é ativo sobre octil $\beta$-glucosídeo. Esses materiais (Q1 e Q2) foram a seguir aplicados separadamente em cilindros de eletroforese de gel de poliacrilamida preparados segundo Hedrick \& Smith (1968). No caso do material Q2 os cilindros eram formados por um segmento inicial de $2 \mathrm{~cm}$ com acrilamida $7 \%$ e um segmento final de $6 \mathrm{~cm}$ com acrilamida $8 \%$. No caso do material ativo sobre celobiose e pN $\phi \beta g l u$ (QI), utilizou-se um cilindro de gel de poliacrilamida 8\%. A eletroforese era desenvolvida a $4^{\circ} \mathrm{C}$ com uma corrente de $2,5 \mathrm{~mA}$ por cilindro. Terminada a corrida, os géis eram lavados a $4^{\circ} \mathrm{C}$ com tampão citrato fosfato $10 \mathrm{mM} \mathrm{pH} 6,0$ por um período de 1 hora, com trocas de tampão a cada 15 minutos. para remoção do Tris.

Após esse procedimento, os géis eram fracionados em um fracionador de géis de poliacrilamida com o mesmo tampão da lavagem na concentração de $100 \mathrm{~mm}$. Foram coletadas frações de $400 \mu l$ no caso dos cilindros onde aplicou-se o material ativo sobre $\mathrm{pN} \phi \beta$ glu e octil $\beta$-glucosideo (Q2) e de $300 \mu l$ dos cilindros onde aplicou-se $\circ$ material ativo sobre celobiose e pN $\phi \beta g l u$ (Q1). Estas frações permaneceram na geladeira a $4^{\circ} \mathrm{C}$ por 3 horas antes de serem utilizadas como fonte de enzimas para os ensaios.

\subsection{Inativação térmica}


As frações eluídas da coluna mono $Q$ que apresentavam atividade sobre celobiose e pN $\phi \beta g l u$ foram reunidas. O mesmo foi feito com as frações

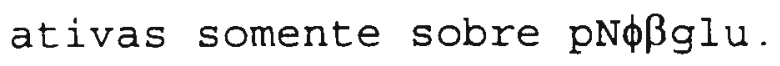

Estes 2 materiais foram submetidos a inativação térmica a $60^{\circ} \mathrm{C}$ por diferentes intervalos de tempo em tampão citrato fosfato $100 \mathrm{mM} \mathrm{pH} \mathrm{6,0.} \mathrm{A} \mathrm{atividade}$ enzimática obtida em cada um dos tempos foi expressa como porcentagem da atividade inicial $(\%$ de atividade remanescente).

Em outra série de experimentos, o material ativo sobre celobiose e pN $\phi \beta g l u$ foi submetido a uma préinativação a $60^{\circ} \mathrm{C}$ por 40 minutos e em seguida inativado a $65^{\circ} \mathrm{C}$ por diferentes intervalos de tempo. Tanto a pré-inativação como a inativação foram realizados em meio com tampão citrato-fosfato $100 \mathrm{~mm}$ $\mathrm{pH} 6,0$.

2.16 Determinação do efeito da concentração de substratos na atividade de $\beta$-glucosidases.

Essa determinação foi feita inicialmente utilizando-se como fonte de enzima o conjunto das frações ativas sobre octilßglu e pN申ßglu (Q2) obtidas após cromatografia em Mono $Q$ (ver item 2.10 e 2.14). As determinações foram realizadas na ausência ou na presença de Triton X-100 2,4mM (10 CMC). Utilizou-se como substrato uma série de alquil $\beta$-glucosídeos (6 a Il carbonos no radical alquil) e metil $\beta$-glucosídeo.

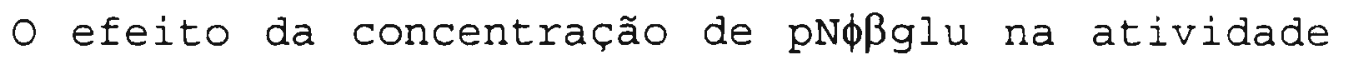
enzimática foi determinado usando como fonte de 
enzimas as frações ativas sobre octil $\beta$-glucosídeo e pN $\phi \beta g l u$ obtidas após eletroforese do material Q2 (ver item 2.14)

o material ativo sobre celobiose e pN $\phi \beta g l u$ eluído de cromatografia em Mono $Q$ (Q1) (ver item 2.10 e 2.14) foi utilizado para este tipo de experimento sendo usado como substrato celobiose, $p N \phi \beta g l u$, laminaribiose e salicina. As determinações foram realizadas com este material antes e após uma incubação do mesmo a $60^{\circ} \mathrm{C}$ por 40 minutos.

Em todos os experimentos, pelo menos 10 concentrações de substrato foram utilizadas.

- programa Enzfitter (Leatherbarrow R.J., Elsevier - Biosoft, 1987) foi usado para determinar o $K_{m}$ e $V_{\text {máx. }}$.

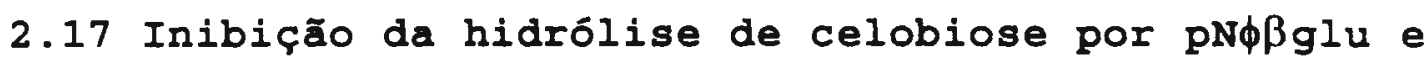

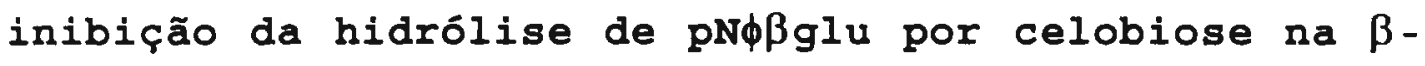
glucosidase termoestável.

o material eluído de Mono Q ativo sobre celobiose e pN $\phi \beta g l u$ (Q1) (item 2.14) foi incubado a $60^{\circ} \mathrm{C}$ por 40 minutos. A atividade sobre celobiose não é afetada por essa incubação, enquanto parte da atividade sobre pN $\phi \beta g l u$ é perdida. Essa atividade remanescente foi denominada de $\beta$-glucosidase termoestável e utilizada no experimento abaixo.

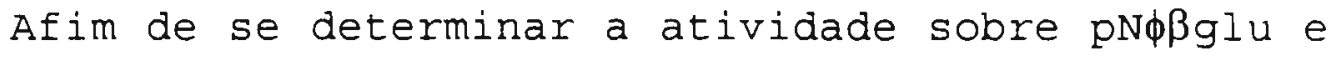
sobre celobiose quando os substratos encontravam-se presentes simultaneamente nos meios de incubação, uma 
alíquota era retirada de cada amostra para determinar p-nitrofenolato, e daí estimar a hidrólise de pN $\phi \beta$ glu, e outra alíquota era utilizada para medida de glicose. A determinação de glicose nesse experimento era feita adicionando-se $\mathrm{H}_{2} \mathrm{SO}_{4}$ ao final da incubação com 0 reagente de glicose-oxidase-peroxidase (Dahlquist, 1968). Nessas condições, $\circ$ pnitrofenolato encontra-se protonado e não interfere na leitura da absorbância. Após descontar-se (a partir das medidas de p-nitrofenolato) as moléculas

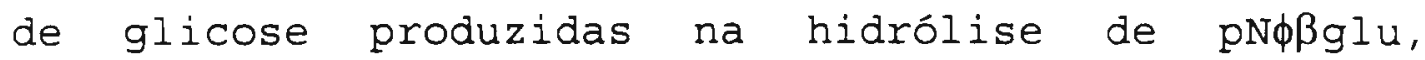
obtinha-se uma medida da atividade sobre celobiose. Assim, calculada a velocidade de hidrólise dos substratos em cada um dos casos, é possível através e do replote das inclinações do plote de LineweaverBurk versus a concentração de um dos substratos determinar a constante de dissociação do outro substrato (Segel, 1975).

2.18 Inibição da hidrólise de octil $\beta$-glucosídeo por

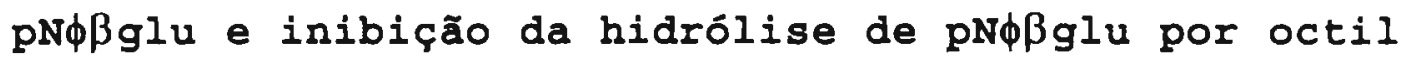
$\beta$-glucosídeo.

Nestes experimentos foi utilizado 0 material

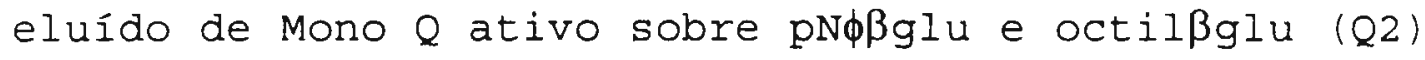
(ver item 2.12).

A determinação dos produtos e o cálculo de $\mathrm{Ki}$ foram realizados do modo descrito no ítem anterior $(2.17)$. 
2.19 Inibição da atividade de $\beta$-glucosidase por glucono $\delta$-lactona e $\gamma$ galactona lactona.

Neste experimento foi utilizado o material eluido da coluna de Mono $Q$ e ativo sobre celobiose e pN $\phi \beta g l u$ (Q1) incubado a $60^{\circ} \mathrm{C}$ por 40 minutos e 0 material eluído de Mono $Q$ ativo sobre octil $\beta$-glucosídeo (Q2). Os substratos usados para o material Q1 foram

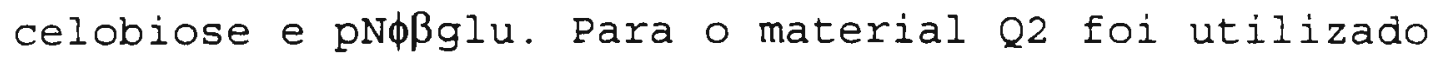
como substrato octil $\beta$-glucosídeo. No caso do material $Q 1$ os inibidores usados foram a glucono $\delta$ lactona e a $\gamma$ galactona lactona, enquanto que para o material Q2 empregou-se somente a glucono $\delta$-lactona. Utilizou-se pelo menos 5 concentrações de inibidor em cada uma das 5 concentrações de substrato.

Tomou-se o cuidado de determinar-se qual era a taxa de hidrólise espontânea de glucono $\delta$-lactona nas condições de ensaio. Essa foi levada em conta para calcular a concentração média dessa substância durante os ensaios.

Os Kis foram calculados a partir dos replotes da inclinação obtida nos plotes de Lineweaver-Burk versus a concentração de inibidor.

2.20 Determinação do pH ótimo de hidrólise da celobiose e octil $\beta$-glucosídeo.

Para determinação do pH ótimo de hidrólise da celobiose utilizou-se o material Q1 (ver item $2.8 \mathrm{e}$ 2.12) eluído de Mono $Q$ incubado a $60^{\circ} \mathrm{C}$ e quando 0 substrato era octilßglu empregou-se o material eluido 
de Mono $Q$ e ativo exclusivamente sobre este substrato (material Q2 - ver item 2.8 e 2.12).

Os tampões, a celobiose e o octil $\beta$-glucosídeo foram preparados, respectivamente para concentrações finais de $50 \mathrm{mM}, 14 \mathrm{mM}$ e $4 \mathrm{mM}$. O pH foi medido numa mistura contendo substrato-tampão nas condições de concentração e temperatura utilizadas para cada ensaio. Esse cuidado deve ser tomado, uma vez que os tampões contém grupos cuja ionização pode ser afetada pela temperatura.

2.21 Determinação da configuração anomérica da Dglicose liberada pela $\beta$-glucosidase ativa sobre octil $\beta$-glucosídeo.

A configuração da glicose liberada pela $\beta-$ glucosidase ativa sobre octil $\beta$-glucosídeo foi determinada incubando-se o substrato (octilßglu) preparado em tampão acetato $10 \mathrm{mM} \mathrm{pH} \mathrm{6,0} \mathrm{com} \mathrm{a} \mathrm{enzima}$ em um banho a $30^{\circ} \mathrm{C}$ por 2 horas. O tampão acetato foi utilizado porque o fosfato acelera o processo de anomerização (Schray \& Benkovic, 1978). Ao término deste tempo de incubação, a reação era inibida com a adição de glicono $\delta$-lactona $1 \mathrm{~mm}$. Uma alíquota de 0,1 ml era retirada antes e após fervura da mistura da reação. Às alíquotas adicionava-se $1 \mathrm{ml}$ do reagente de glicose oxidase-peroxidase (Dahlquist, 1968) e a absorbância era lida continuamente a $420 \mathrm{~nm}$.

Os controles foram preparados como as amostras experimentais, substituindo o substrato por uma solução de $\alpha$-D-glicose recém preparada ou por uma 


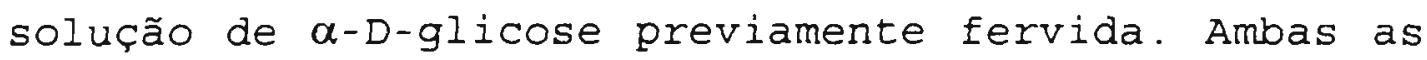
soluções continham glicose com concentração igual a das amostras experimentais. Os controles foram incubados por 30 minutos antes da adição de glicono $\delta$ lactona e o reagente de glicose oxidase - peroxidase.

A ausência de mutarrotase em nossas preparações foi assegurada pelos resultados idênticos obtidos na incubação de $\alpha$-D-glicose com o reagente de glicose oxidase-peroxidase na presença e ausência da fonte de enzimas.

\section{3- RESULTADOS}

\section{1- Distribuição intracelular de enzimas digestivas} em diferentes períodos após uma refeição.

Uma vez que o estado alimentar poderia influenciar na secreção de enzimas digestivas. animais foram dissecados em diferentes períodos após uma refeição e os cecos anteriores coletados como descrito em Materiais e Métodos.

Os animais foram inicialmente submetidos a 24 horas de jejum para que tivéssemos uma grande probabilidade de que eles iriam alimentar-se quando colocados em contato com a comida. A refeição era sempre fornecida às 12 horas, porque no campo, esse é - horário em que eles se mostram mais ativos (Dr. Alejo Mesa, comunicação pessoal).

É Conhecido que Schistocerca gregaria, outro Orthoptera, esvazia o conteúdo dos cecos para o ventrículo após uma refeição e então gradualmente ele 
vai sendo novamente preenchido. Três horas após a refeição, esse volume é mínimo (Dow, 1981). Desse modo, 3 horas deve assinalar algum evento no ciclo digestivo. Com base nesse dado, escolhemos o tempo de 3 horas e outros dois tempos ao redor desse 1 e 5 horas) para determinarmos a distribuição intracelular das enzimas digestivas. Como o número de animais $e$ determinações enzimáticas envolvidas nesse experimento era grande, decidimos realizar um fracionamento subcelular simplificado.

Conforme descrito em Materiais e Métodos, obtivemos três frações subcelulares a partir dos cecos anteriores. A fração solúvel (denominada $S$ ), a fração de membranas obtida após o material precipitado ser submetido a congelamentos sucessivos (denominada PM) e a fração solubilizada após o material precipitado ser submetido a congelamentos sucessivos (denominada SM).

Algumas das enzimas digestivas que são detectadas no lúmen do intestino foram ensaiadas nessas frações e os resultados estão apresentados na figura 2 .

Observando a atividade específica relativa dessas várias enzimas nas frações subcelulares notamos que quando se usa amido, celobiose e maltose como substrato obtem-se um padrão de distribuição da atividade enzimática semelhante. Nos tempos 0,1 e 5 horas a atividade específica relativa na fração SP é menor que na fração SF. Exceção feita a fração SP no tempo 0 e 5 horas da amilase, pois se levarmos em 

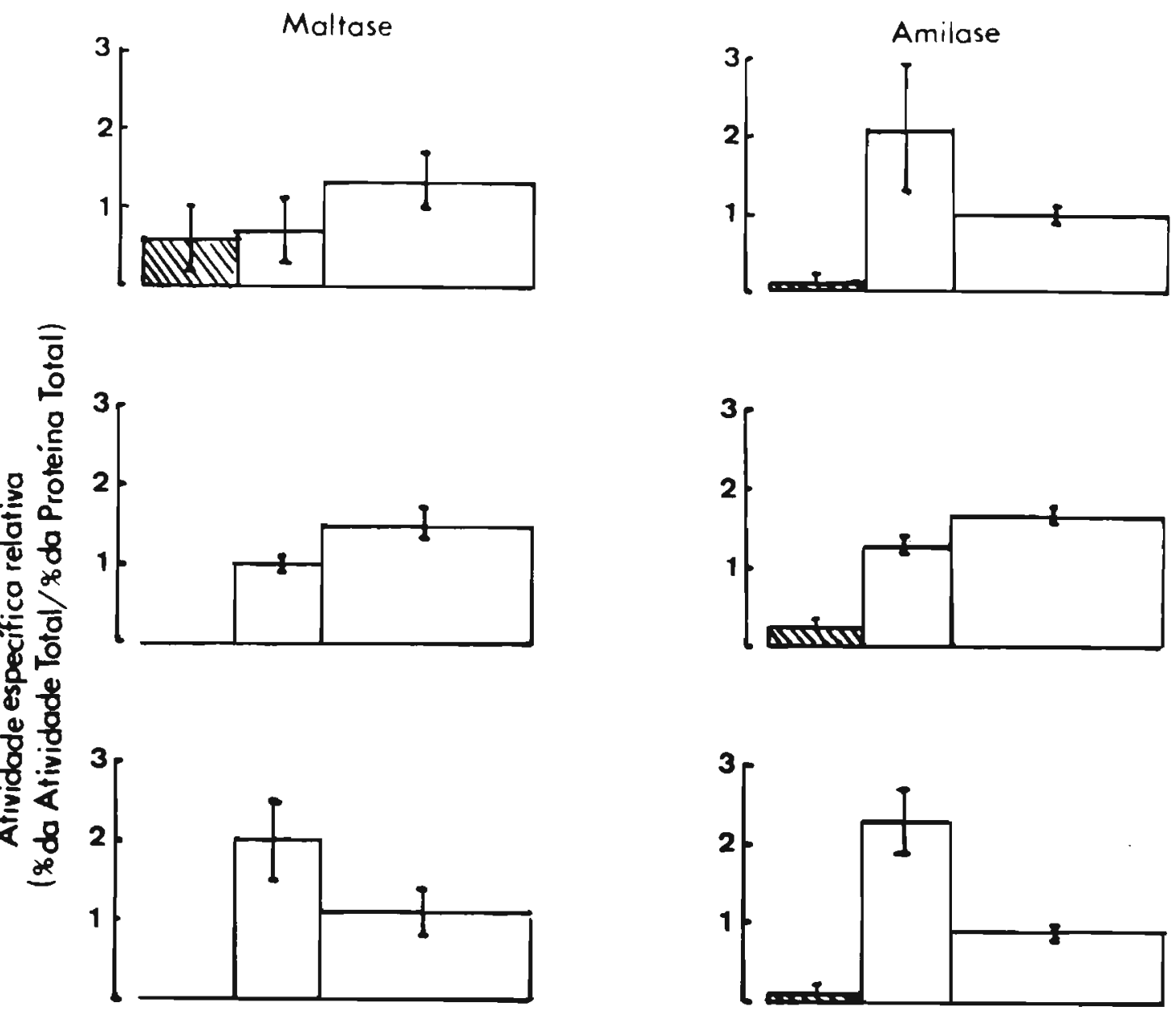

Oh

1h

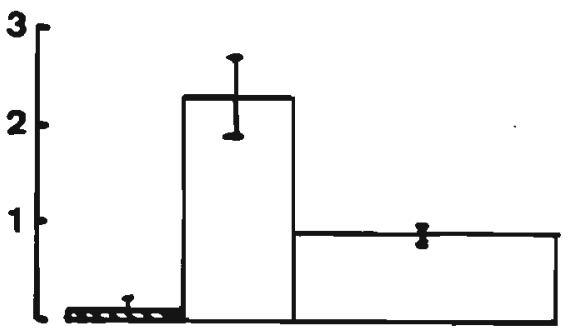

3h
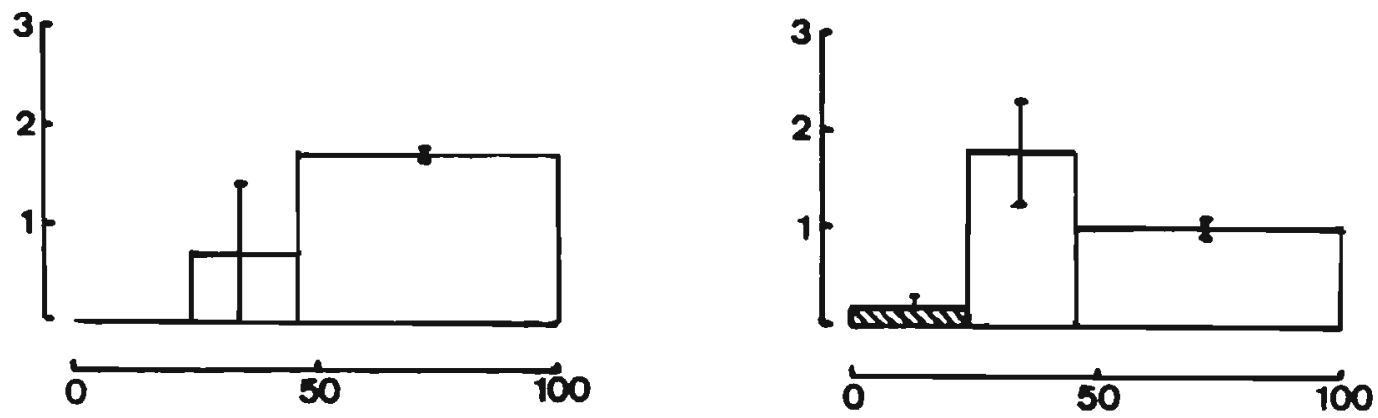

* da Proteina Total

Figura 2 - Distribuição subcelular de enzimas digestivas em diferentes períodos após a refeição (continua na próxima página). Os resultados são apresentados segundo De Duve et al. (1955). Da esquerda para a direita estão apresentadas as frações na ordem em que foram obtidas. PM, SM (respectivamente precipitado e sobrenadante da centrifugação a $100.000 \mathrm{xg}$ por 1 hora de um sedimento $100.000 \mathrm{xg}$ por 1 hora congelado e descongelado 3 vezes) e S (sobrenadante da centrifugação do homogeneizado inicial a $100.000 \mathrm{~kg}$ por $1 \mathrm{~h}$ ). Os dados são média e desvio padrão da média de determinações realizadas em 3 preparações feitas com 2 animais cada 


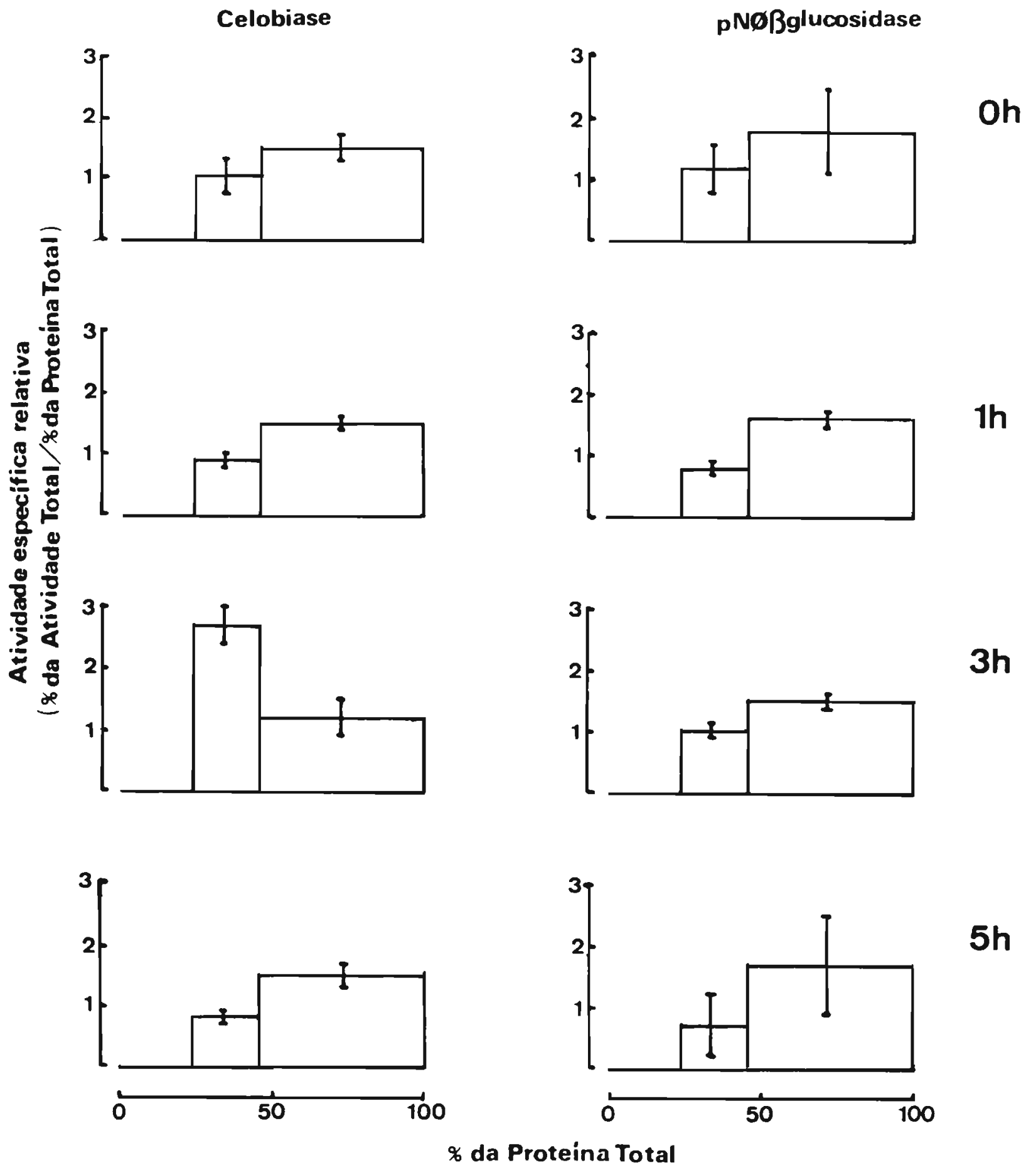

Figura 2 (continuação) 
consideração os desvios as frações SP e SF se igualam. Para estas 3 enzimas no tempo 3 horas a Eração SP é a que apresenta maior atividade especifica, sendo a atividade especifica relativa maior que 1 , indicando enriquecimento das referidas enzimas nesta fração. Observa-se que a amilase apresenta uma forma ligada a membrana recuperada na Eração PP que, embora apresente pequena atividade específica relativa, é aproximadamente constante ao longo dos tempos estudados.

No caso do pNфßglu não observamos o padrão de aumento de atividade no tempo de 3 horas. Ao longo dos diferentes tempos a proporção de atividade especifica relativa entre as frações subcelulares permaneceu aproximadamente constante. A fração SF sempre apresenta a maior atividade especifica relativa.

Uma vez que enzimas presentes em grânulos de secreção seriam recuperadas na fração SP, optamos por dissecar os animais 3 h após a alimentação.

\section{2- Distribuição subcelular de enzimas digestivas presentes nos cecos anteriores.}

Fracionamentos subcelulares dos cecos anteriores foram realizados como descrito em Materiais e Métodos. Foram utilizados somente machos que tinham jejuado por 24 horas, alimentado-se por 20 minutos a partir das 12 horas e dissecados 3 horas após a alimentação. Os resultados obtidos para 9 enzimas estão apresentdos na figura 3 . 

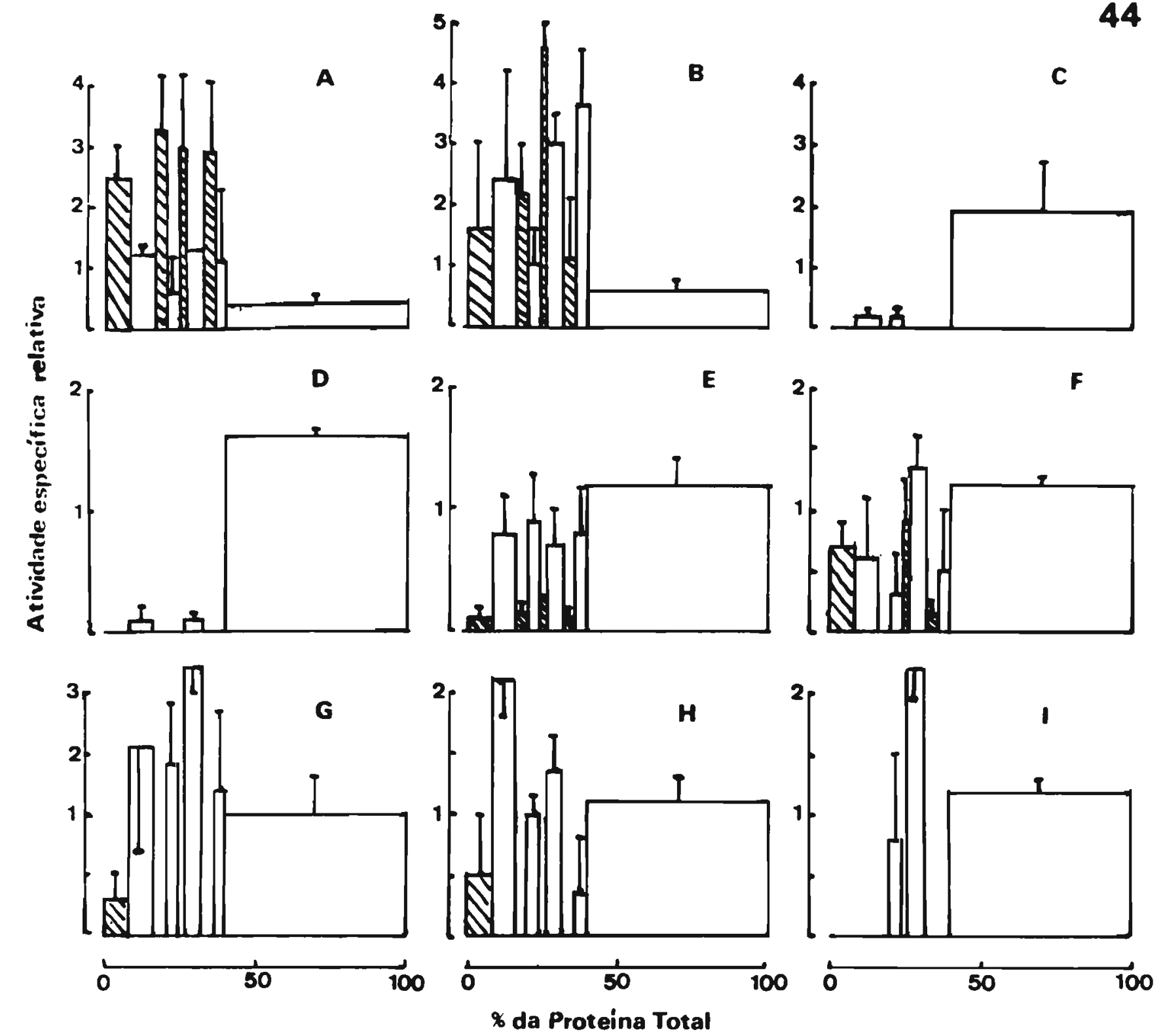

Figura 3 - Centrifugação diferencial de homogeneizados dos cecos anteriores de A. flavolineata adultos. Meio de homogeneizaçãc: manitol $471 \mathrm{mM}$, fosfato bibásico de sódio 2 mM, $\mathrm{pH}$ 7,0. Paralelogramos claros correspondem aos sobrenadantes e hachurados aos precipitados. Os dados são média e desvios da média baseados em 3 preparações obtidas com 2 individuoas cada. Da esquerda para direita estão dispostos PP1, SP1, PP2, SP2, PP3, SP3, PP4, SP4 e SF. Áreas em branco significam ausência de atividade enzimática naquela fração. Maiores detalhes ver Materiais e Métodos e figura 1. A, SOH; B, Y glutamil transferase; C, LDH; D, Tripsina; E, Dipeptidase; F, Aminopeptidase; G, Amilase; H, Maltase; I, pN $\phi$ Bglu hidrolase. 
A LDH foi utilizada como enzima marcadora da fração solúvel celular (citossol) e SDH como marcadora de mitocôndrias. $\gamma$ glutamil transferase foi ensaiada no intuito de encontrarmos uma enzima marcadora de membrana plasmática, uma vez que essa enzima é detectada ligada a membranas microvilares intestinais em alguns insetos, entre eles Musca domestica (Espinoza - Fuentes et al, 1987) e Erinnyis ello (Santos \& Terra, 1986).

Uma inspeção na figura 3 mostra que LDH é recuperada quase totalmente no sobrenadante final. A atividade de $\mathrm{SDH}$ é mais enriquecida (高高 > 1) nas frações particuladas (PPI, PP2, PP3 e PP4). Entretanto, é estranhamente alta a atividade dessa enzima nas frações solúveis.

$\gamma$ glutamil transferase é recuperada tanto nas frações particuladas como nas frações solúveis. 0 enriquecimento alcançado é similar em ambos os casos. Este resultado sugere a existência de uma forma solúvel e outra associada a membrana para esta enzima.

A tripsina apresenta uma distribuição subcelular semelhante a da $\mathrm{LDH}$. Com atividade recuperada quase totalmente no sobrenadante final (SF).

A aminopeptidase e a dipeptidase apresentam uma distribuição muito semelhante. Ambas estão presentes nas frações particuladas e solúveis, sendo que a maior atividade é recuperada no sobrenadante final. Esta fração é ligeiramente enriquecida das duas enzimas. A aminopeptidase tem a maior atividade 
específica no sobrenadante da fração P3. O resultado sugere a existência de uma forma particulada e outra solúvel para estas 2 enzimas.

A amilase, a maltase e a hidrolase de pN申ßglu apresentam distribuições semelhantes, com praticamente toda atividade solúvel e grande quantidade de enzima presente no sobrenadante final. Enriquecimento somente é observado nas frações solúveis derivadas das frações particuladas.

Como comentado anteriormente, a atividade de SDH é recuperada tanto nas frações particuladas como nas frações solúveis. Uma possível explicação para esse resultado seria a ressuspensão de parte do sedimento na hora de coletar-se o sobrenadante. Entretanto, devido a alta atividade recuperada nas frações solúveis, essa não deve ser, pelo menos isoladamente, a causa desse resultado. Outra explicação plausível é a de que o manitol presente no meio de homogeneização torna esse meio viscoso não permitindo a sedimentação total dos pequenos fragmentos de membrana mitocondrial.

A viscosidade do manitol poderia também não permitir a sedimentação de grânulos de secreção que seriam recuperados na fração P4. As enzimas presentes nesses grânulos seriam recuperadas na fração solúvel celular.

Para verificar se a sedimentação de membranas estava sendo prejudicada nas condições empregadas, novos fracionamentos subcelulares foram realizados em condições semelhantes àqueles cujos resultados estão 
apresentados na figura 3. Porém, em toda fase onde o material fosse centrifugado a $100.000 \mathrm{xg}$, o tempo de centrifugação utilizado foi de 3 horas ao invés de 1 hora. Os resultados obtidos para SDH, $\gamma$ glutamil

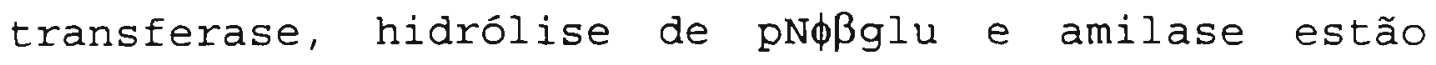
apresentados na figura 4 .

Aparentemente, a centrifugação por 3 horas leva a uma sedimentação maior do material. A quantidade de proteína presente na fração solúvel celular obtida por 1hora de centrifugação (figura 3) é cerca de $60 \%$ da proteína total, enquanto a mesma fração, após ser centrifugada 3 horas apresenta menos de $40 \%$ de toda proteína (figura 4).

Grosso modo, a distribuição de SDH e $\gamma$ glutamil transferase é a mesma quando as centrifugações são feitas a $100.000 \mathrm{xg}$ por 1 hora ou por 3 horas. Isto é, continuamos encontrando uma forma solúvel e uma Iigada a membrana. O mesmo pode ser dito da amilase e da hidrolase de pN $\phi \beta g l u$, no sentido que temos somente atividade solúvel para essas duas enzimas.

Como nenhuma enzima foi detectada somente na membrana plasmática das células dos ventrículos anteriores de $\underline{A}$. flavolineata $e$ seria interessante termos um marcador enzimático para essa estrutura, tentamos ensaiar fosfatase alcalina. Para isso homogeneizados das células do ceco anterior foram feitos em água. Esses homogeneizados foram centrifugados a $100.000 \mathrm{xg}$ por 1 hora. Apenas $30 \% \mathrm{da}$ atividade total de fosfatase alcalina foi recuperada na fração de membrana, indicando que esta enzima 

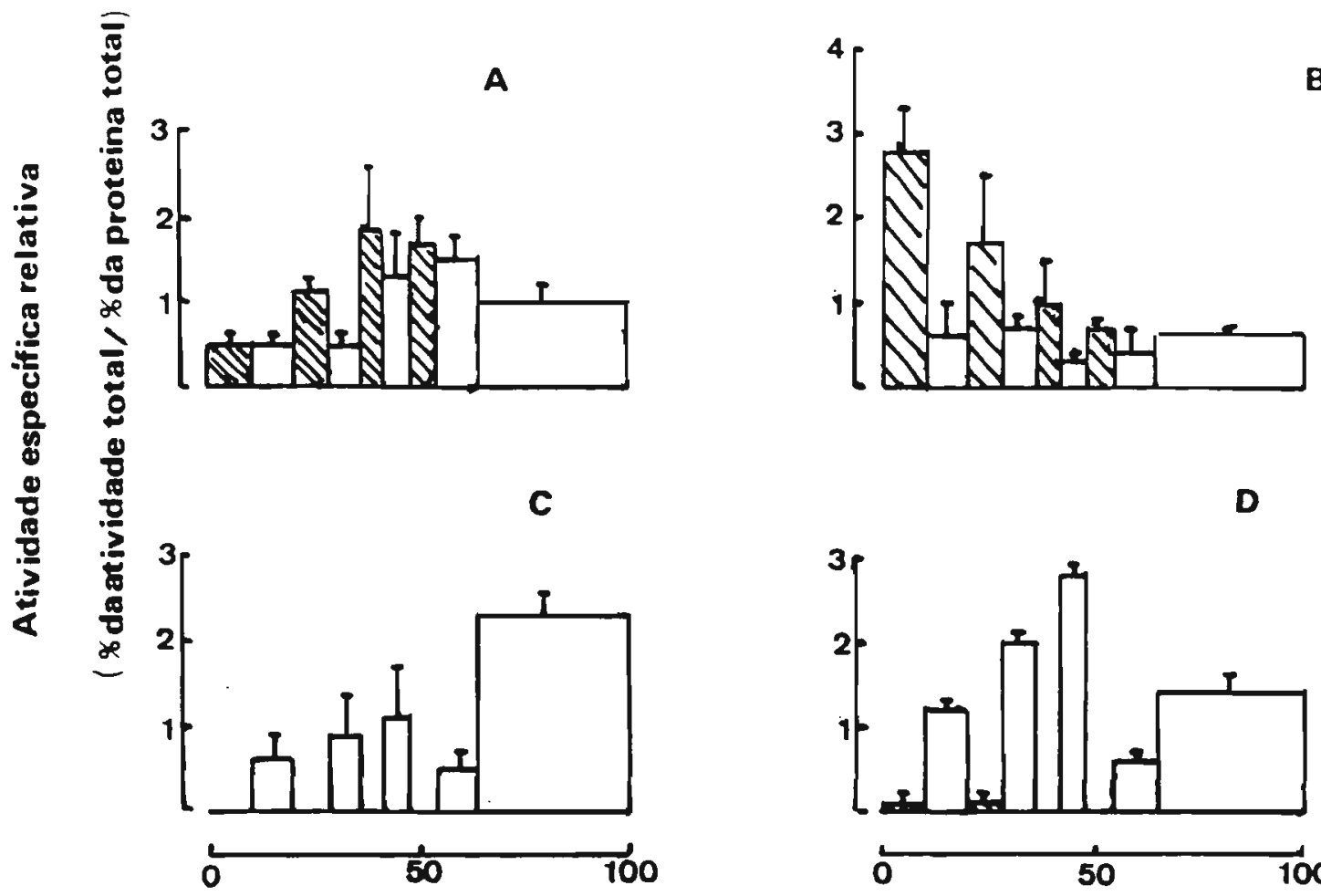

B 
também não é um marcador de membrana plasmática nesse inseto.

\subsection{Purificação de $\beta$-glicosidases}

- Iíquido viscoso coletado da cavidade oral de $\underline{A}$. flavolineata apresenta enzimas originárias do lúmen do intestino médio, exceto por uma amilase que é salivar (Ferreira et al., 1990b). Parte dos objetivos desta dissertação consiste na determinação do número e propriedades das $\beta$-glicosidases digestivas desse inseto. Assim, uma vez que não foi detectada atividade $\beta$-glicosidásica ligada a membrana, decidimos usar como fonte de material o regurgitado, que permite coletar as enzimas sem dissecar os animais. Como primeira tentativa de separar as $\beta$ glicosidases presentes no regurgitado, este material (aproximadamente $16 \mathrm{mg}$ de proteína) foi aplicado em uma coluna de filtração em gel (Superose 12) no FPLC.

- perfil de eluição das atividades enzimáticas

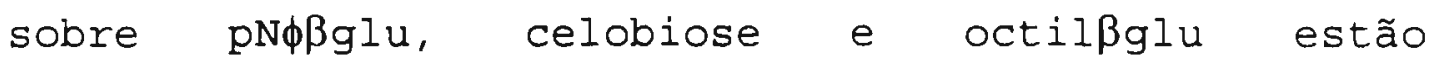
apresentados na figura 5. A atividade enzimática sobre os 3 substratos é recuperada em um único pico praticamente coincidente. Através de uma curva de calibração com os seguintes padrões: citocromo C (Mr 12.400), ovalbumina (Mr 45.000), aldolase (Mr 65.000), L-aminoácido oxidase (Mr 89.000), álcool desidrogenase $(150.000)$ e $\beta$-amilase (Mr 200.000) foi possível descobrir que os picos de atividade enzimática coeluiam na região de Mr 82.000. observando a figura 5 notamos que os picos de atividade sobre celobiose e octil $\beta$-glucosideo 


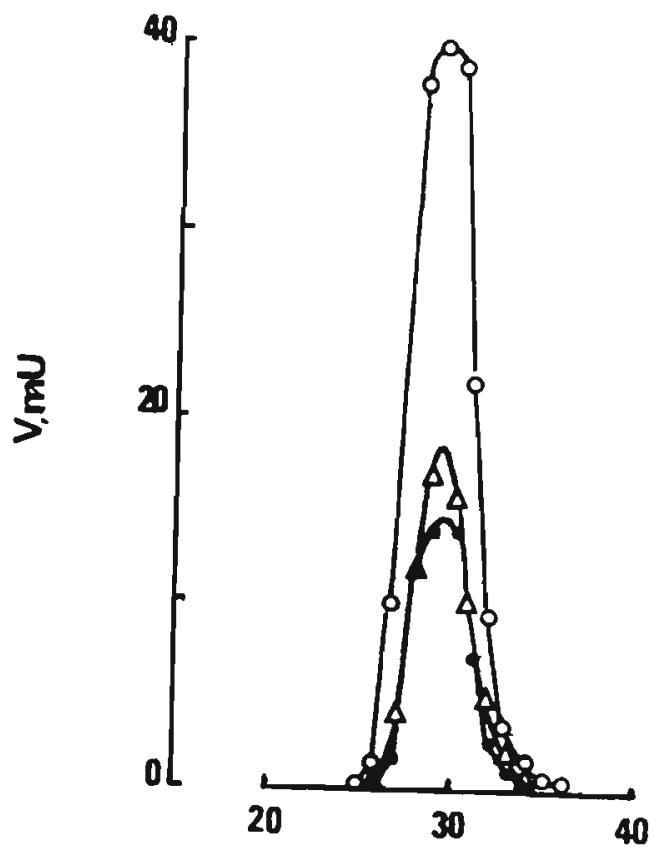

Fraction, no.

Figura 5 - Filtração em gel das $\beta$-glicosidases intestinais de A. flavolineata em coluna de superose $12 \mathrm{HR} 10 / 30$ (em FPLC). A amostra aplicada foi o material regurgitado. A coluna EO: equilibrada e eluída com tampão citrato-fosfato pH 6,0 . C Eluxo foi de $0.4 \mathrm{ml} / \mathrm{min}$ e foram coletadas frações de $0.4 \mathrm{ml}$.

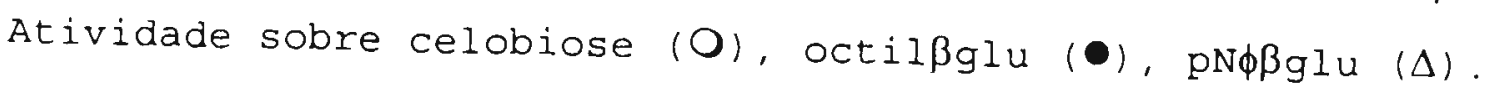


apresentam uma morfologia diferente. Além disso as recuperações também diferem ( celobiose $=54 \%$, octil $\beta$-glucosídeo $=85 \%)($ tabela 2$)$. Estes dados sugerem a existência de mais que uma $\beta$-glucosidase no regurgitado de $\underline{A}$. Elavolineata. Embora as enzimas não se separem, este passo de purificação possibilitou um enriquecimento de 3,9 vezes no caso da enzima ativa sobre octilßglu e 4,8 vezes da enzima ativa sobre celobiose. Deste modo, a filtração em gel em superose 12 passou a ser o primeiro passo na marcha para purificação das $\beta$-glicosidases de A. flavolineata.

Para tentar resolver as $\beta$-glicosidases, foram tentados diversos tipos de colunas em diferentes condições. Foram utilizadas as colunas de troca iônica: Mono Q (trocadora de ânions) e Mono $S$ (trocadora de cátions), sendo que a coluna Mono Q foi usada em 4 pHs diferentes $(6,2 ; 7,5 ; 8,0 ; 8,5)$. Foi também usada a coluna de Alquil-Superose, que separa proteínas com base em sua hidrofobicidade e coluna Mono $P$, que baseia-se em diferenças de ponto isoelétrico. Todas essas colunas foram utilizadas usando-se o sistema de FPLC.

Para serem aplicadas nas colunas Mono $Q$ e Mono $P$ as proteínas devem estar em um tampão com pH superior ao seu $\mathrm{pI}$, sendo o inverso para a coluna Mono S. Para aplicação na coluna Alquil-Superose recomenda-se um tampão com pH 5,5. Como a eluição das enzimas a partir da coluna de superose 12 é feita com tampão citrato-fosfato pH 6,0, é necessário trocar este tampão por outro que seja adequado à próxima coluna a 
Tabela 2 - Recuperações e enriquecimentos obtidos na purificação de $\beta$-glucosidases a partir do regurgitado de A. flavolineata

\begin{tabular}{|c|c|c|c|c|c|c|}
\hline & \multicolumn{3}{|c|}{ Octilßglu } & \multicolumn{3}{|c|}{ Celobiose } \\
\hline Fração & $\begin{array}{l}\text { At . esp. } \\
(\mathrm{mU} / \mathrm{mg})\end{array}$ & $R(\xi)$ & FE $(\mathbf{x})$ & $\begin{array}{l}\text { At. esp } \\
(\mathrm{mU} / \mathrm{mg})\end{array}$ & R $(\%)$ & FE $(x)$ \\
\hline Regurgitado & 263 & 100 & 1 & 1103 & 100 & 1 \\
\hline Superose 12 & 1021 & 85 & 3,9 & 5323 & 54 & 4,8 \\
\hline Mono $Q$ & 1277 & 18 & 4,9 & 5341 & 18 & 4,8 \\
\hline
\end{tabular}

At. esp. = Atividade específica

$\mathrm{R}$ = Recuperação da atividade enzimática em relação ao regurgitado inicial

$\mathrm{FE}=$ Fator de enriquecimento da atividade especifica 
ser usada. A coluna de Fast Desalting permitiu a realização dessa tarefa em curto espaço de tempo com boa recuperação. Obteve-se uma recuperação de $95 \%$ da atividade enzimática aplicada a coluna com uma diluição de 1,2 vezes, no caso da troca de tampão citrato-fosfato $20 \mathrm{mM}$ pH 6,0 para trietanolamina 20 $\mathrm{mM}$ pH 8,0 .

Após filtração em gel (Superose 12), as frações contendo atividade de $\beta$-glucosidase (figura 5) foram reunidas. Após a troca de tampão na coluna de Fast Desalting, esse material foi submetido a uma cromatografia de troca iônica em coluna de Mono s no FPLC. Foi utilizado na cromatografia tampão fosfato $10 \mathrm{mM} \mathrm{pH}$ 5,5. Embora $\circ \mathrm{pH}$ do tampão utilizado estivesse mais de uma unidade abaixo do valor do $\mathrm{pI}$ determinado para as $\beta$-glicosidases, as enzimas não se ligaram a coluna, sendo recuperadas inteiramente quando foi passado o tampão para retirar o material não 1 igado.

Tentamos também usar uma coluna de alquilSuperose. A eluição foi feita com concentrações crescentes de etilenoglicol. Novamente a atividade de $\beta$-glicosidase foi inteiramente recuperada no material que não ligou-se a coluna.

Uma vez que as $\beta$-glicosidases possuem pIs muito próximos, pensamos na possibilidade de separá-las por cromatofocalização, utilizando a coluna Mono $P$ no sistema FPLC. Embora a diferença entre os pIs seja pequena, ela é suficiente para que as enzimas pudessem ser separadas pela cromatofocalização. Após 
realização do experimento, nenhuma atividade enzimática foi detectada utilizando celobiose ou pN $\phi \beta$ glu como substrato. Provavelmente houve inativação total das enzimas, pois na eletrofocalização em gel de poliacrilamida a recuperação era pequena (resultados não mostrados), demonstrando que estas enzimas parecem serem denaturadas em gradientes de $\mathrm{pH}$.

Quando as $\beta$-glicosidases foram cromatografadas em Mono Q com tampão trietanolamina pH 8,0, observamos dois picos de atividade sobre pNoßglu (fig. 6). Um destes picos coincide com um pico de atividade sobre celobiose e o outro com um pico de atividade sobre octilßgli. Este resultado obtido indica que ocorrem pelo menos $2 \beta$-glicosidases no regurgitado de $\underline{A}$. flavolineata. As recuperações em relação ao regurgitado inicial após a filtração em gel (Superose 12) e troca iônica (Mono Q) foram de $18 \%$ tanto para celobiose como para octilßglu e o enriquecimento foi de 4,9 vezes para celobiose e 4,8 vezes para o octil $\beta$ glu.

Uma vez que utilizando trietanolamina foi possível verificar dois picos de atividade enzimática, embora não totalmente separados, decidimos realizar a cromatografia em Mono $Q$ em outros pHs na tentativa de se obter uma melhoria na resolução da atividades $\beta$-glicosidásicas. Entretanto, nas cromatografias realizada nos pHs 8,5 e 7,5, a resolução não aumentou. 


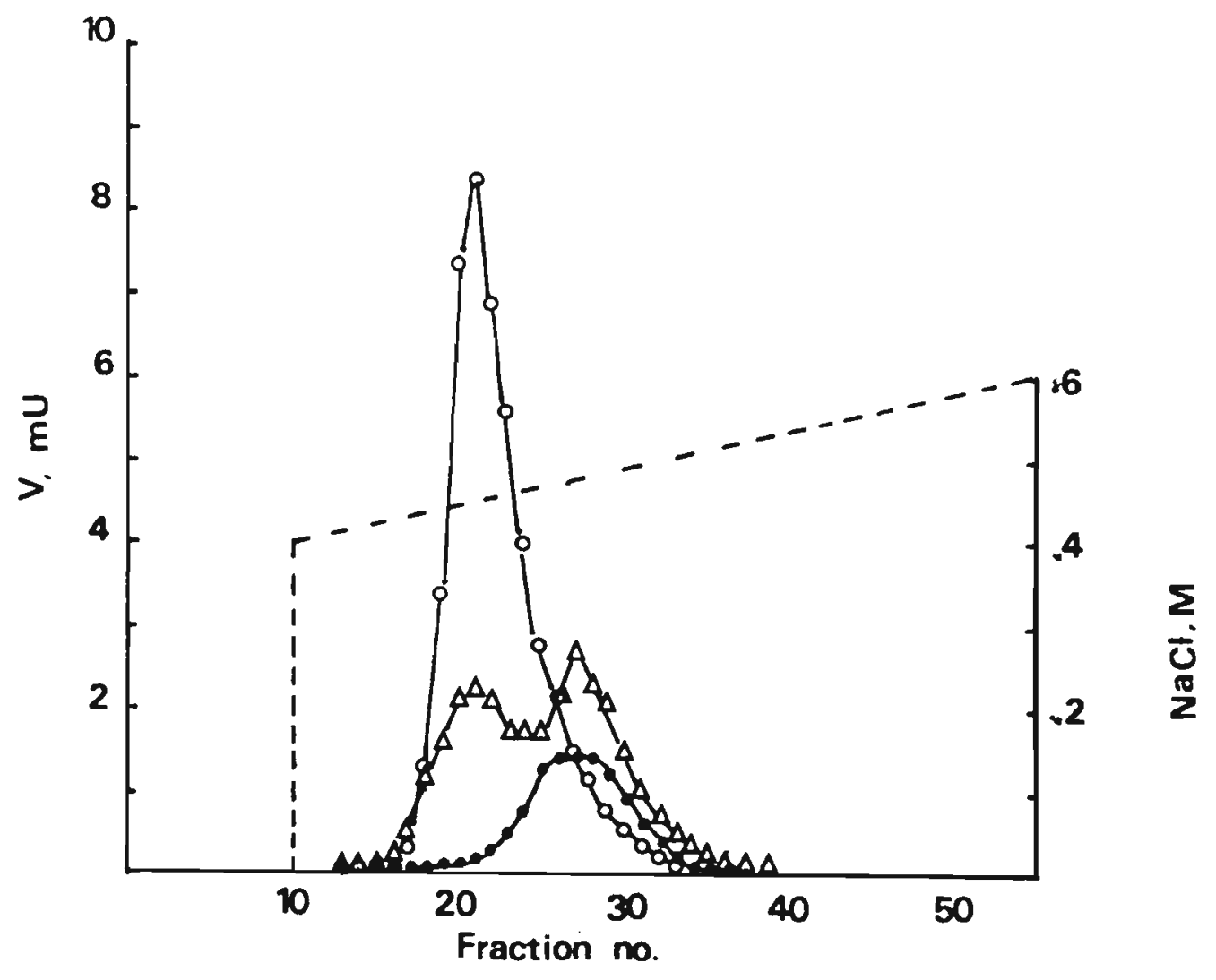

Figura 6 - Cromatografia de troca iônica das $\beta$-glicosidases intestinais de $\underline{A}$. Elavolineata eluídas da coluna superose 12. A coluna Mono $Q$ HR $5 / 5$ (FPLC) foi equilibrada com trietanolamina - $\mathrm{HCl} 10 \mathrm{mM} \mathrm{pH} 8,0$. A coluna foi lavada com 5 ml desse tampão e então eluída com um gradiente de $0,4-0,6 \mathrm{M}$ de $\mathrm{NaCl}$. Foram coletadas frações de $0,4 \mathrm{ml}$ em um fluxo de eluição de $0,5 \mathrm{ml} / \mathrm{min}$. Atividade sobre celobiose (O), octil $\beta$

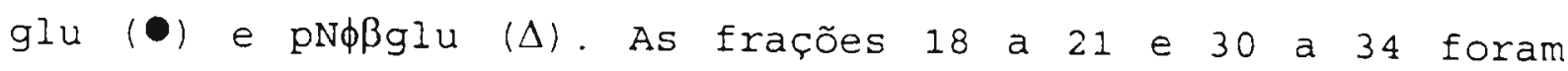
reunidas formando os materiais denominados Q1 e Q2, respectivamente. 
Aparentemente, a melhor resolução possivel dessas $\beta$-glicosidases utilizando coluna de Mono $Q$ é aquela obtida com tampão trietanolamina pH 8,0. Novas cromatografias análogas àquela apresentada na figura 6 foram repetidas e as frações 18 a 21 (ativas sobre

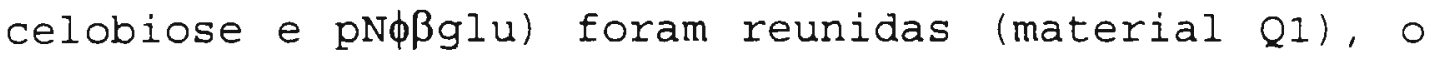
mesmo sendo feito com as frações 30 a 34 (ativas sobre pN $\phi \beta g l u$ e octilßglu - material Q2). Estes dois materiais (Q1 e Q2) foram separadamente submetidos a eletroforese em gel de poliacrilamida.

A figura 7 apresenta o resultado obtido após eletroforese do material Q2. Quando utilizamos pN $\phi \beta$ glu como substrato obtemos 2 picos de atividade. Um deles com máximo de atividade na fração 33 e outro pico com máximo de atividade na fração 28 . Quando foi usada celobiose como substrato para ensaio neste mesmo gel, obteve-se um único pico de atividade enzimática coincidente com o pico minoritário de atividade sobre pN $\phi \beta g l u$. É provável que a enzima presente nesta região e que apresenta atividade sobre os dois substratos corresponda àquela $\beta$-glicosidase presente na frações 18 a 21 da cromatografia em Mono Q (figura 6) e que foi parcialmente coletada junto com a enzima majoritariamente presente nas frações 30 a 34. O ensaio deste mesmo material utilizando octilß glucosídeo como substrato mostra que esse substrato só é clivado em quantidades significativas pela enzima que cliva pNфßglu, mas não celobiose (figura 7C). A enzima que cliva celobiose aparentemente não é capaz de hidrolisar octilßglu. Se utilizamos salicina 

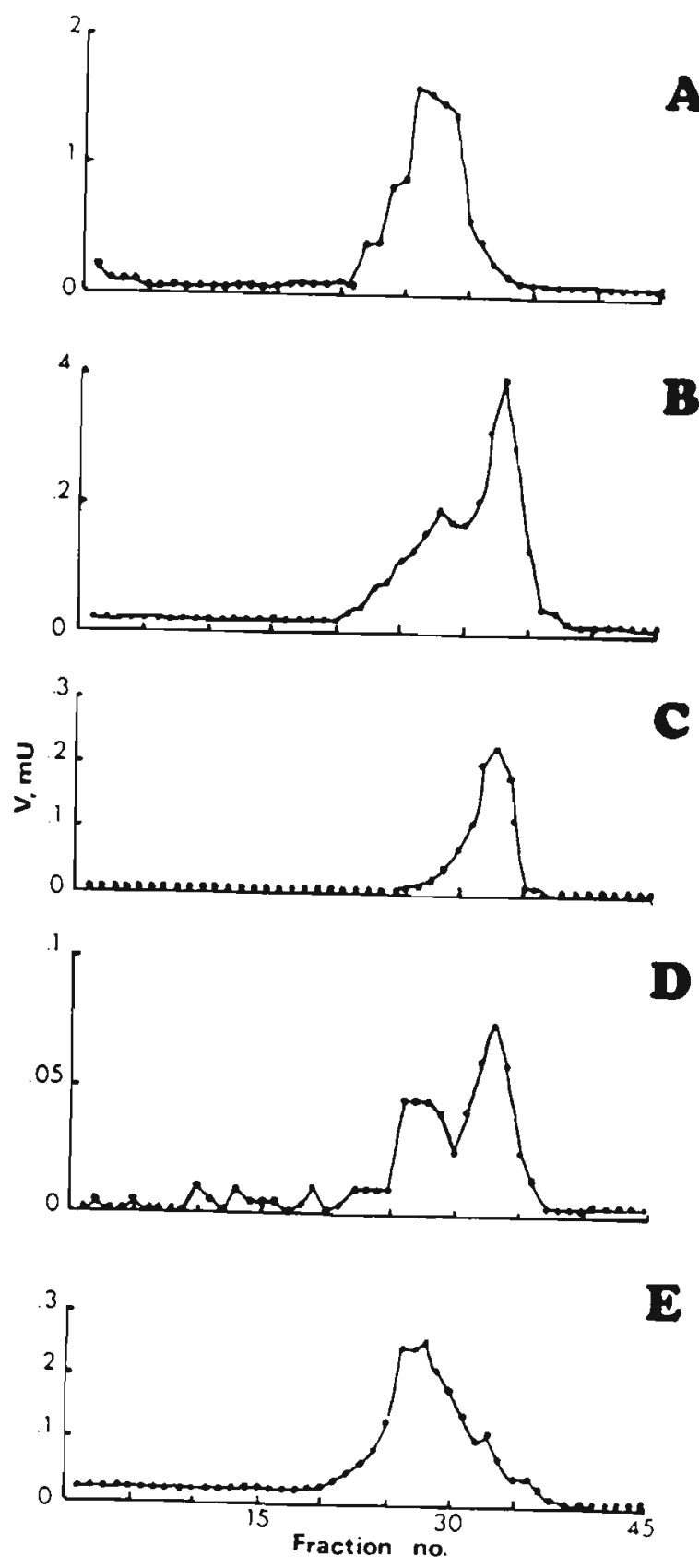

Figura 7 - Eletroforese das $\beta$-glicosidases presentes em Q2 (ver figura 6). Após a eletroforese, o gel de poliacrilamida 7 - 8\% foi fracionado e ensaiado com diferentes substratos. Atividade sobre celobiose (A), pN $\phi \beta g l u$ (B), octilßglu (C), salicina (D) e laminaribiose (E). As frações 33 a 35 foram reunidas e usadas como alquil $\beta$-glucosidase purificada eletroforeticamente. 
como substrato, dois picos de atividade enzimática são detectados coincidentes com os de atividade sobre pN $\phi \beta g l u$.

Após separação do material Q2 por eletroforese, observa-se também, que a enzima capaz de clivar octil Bglu atua sobre uma série de alquil $\beta$-glucosídeos com diferente número de carbonos no radical alquil (6 a 11) (figura 8).

Os resultados obtidos após eletroforese em gel de poliacrilamida das frações 18 a 21 (Q1) da figura 6 estão apresentados na figura 9. Com esse material obtivemos apenas um pico de atividade sobre pN $\phi \beta g l u$ e celobiose. Embora as atividades estejam todas na mesma região, a morfologia dos picos não é simetrica e é diferente quando se utiliza cada um dos substratos, deixando a suspeita da ocorrência de pelo menos duas enzimas diferentes nesse material (Q1). Nenhuma dessas supostas enzimas corresponderia a enzima majoritária que ocorre ns frações 30 a 34 (Q2) analisada acima, uma vez que não houve atividade sobre octilßglu neste gel.

Para testar a hipótese de haver mais de uma $\beta$ glicosidase presente no material Q1 eluido de cromatografia em Mono $Q$, este material (Q1) Eoi submetido a uma inativação térmica a $60^{\circ} \mathrm{C}$. Como pode ser visto na figura 10A, no caso da atividade sobre celobiose, temos um plote linear onde a atividade remanescente é constante e igual a 100\% até 70 minutos. Este resultado sugere indica que existe uma única forma enzimática ativa sobre celobiose e que 

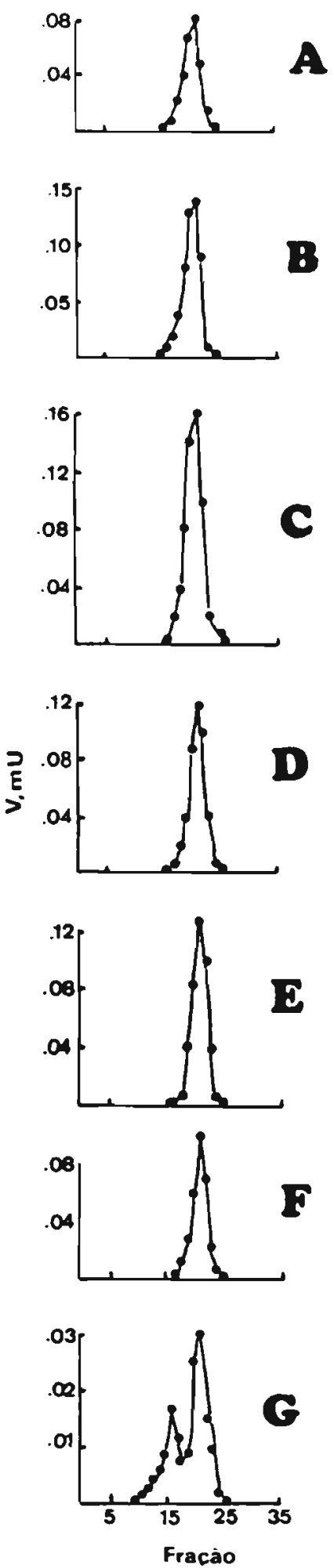

Figura 8 - Eletroforese das $\beta$-glicosidases presentes em Q2 (ver figura 6) em cilindro de poliacrilamida 7 - 8\%. Atividade sobre undecilßglu (A), decilßglu (B), nonilßglu (C), octilßglu

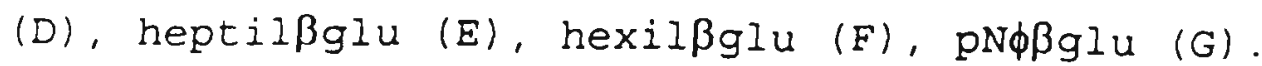



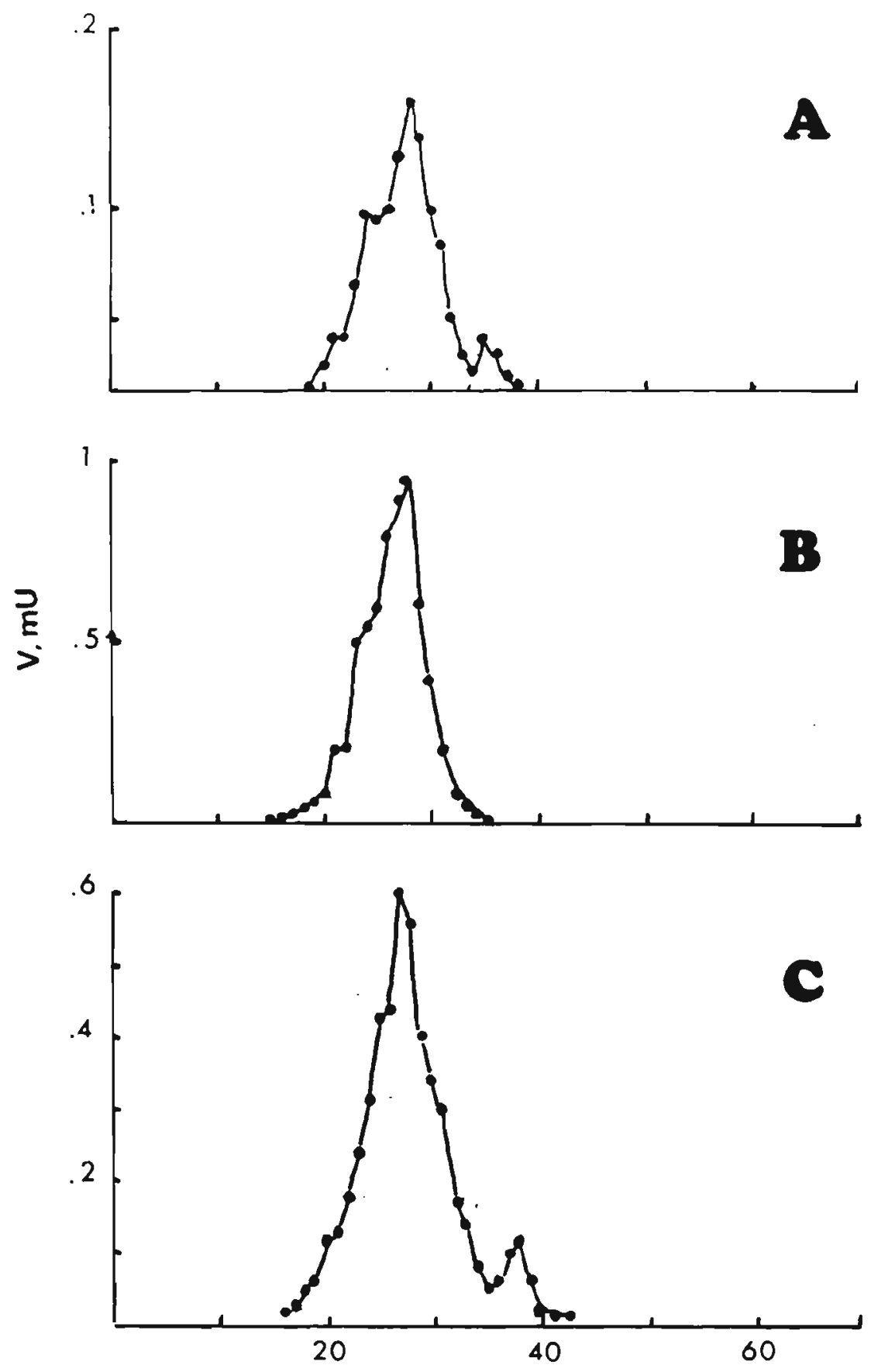

Fraction no.

Figura 9 - Eletroforese das $\beta$-glicosidases presentes em QI ver figura 6). Após a eletroforese em gel de poliacrilamida 8\% 0 cilindro de gel foi fracionado e as frações ensaiadas com

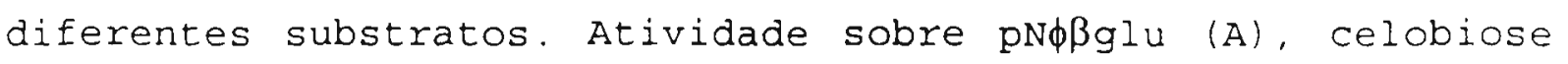
(B) e laminaribiose (C). 


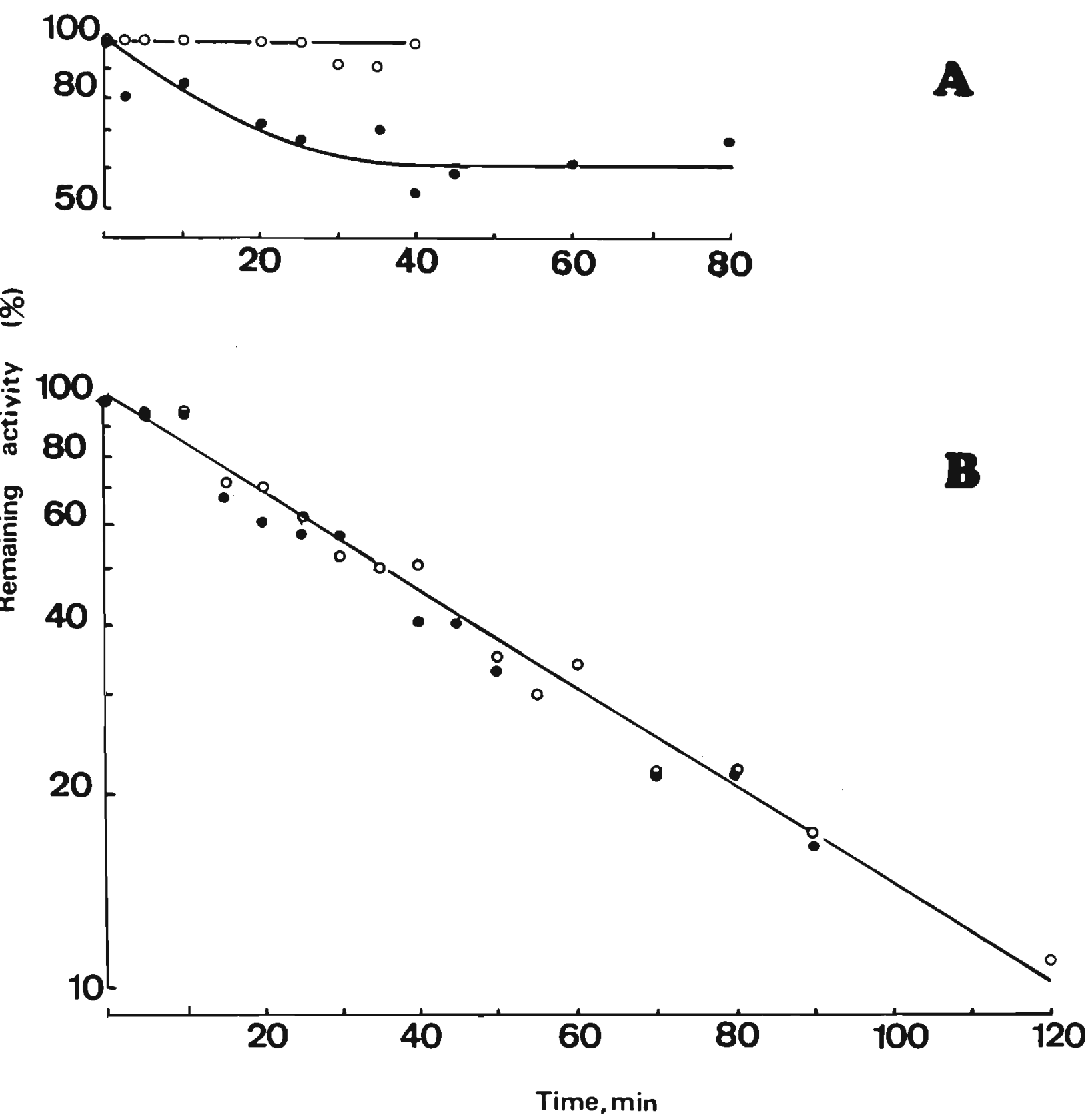

Figura 10 - Inativação térmica das $\beta$-glicosidases presentes em Q1 (ver figura 6). (A) inativação a $60 \mathrm{C}$. (B) inativação a $65^{\circ} \mathrm{C}$ das amostras previamente aquecidas a $60^{\circ} \mathrm{C}$ por 30 minutos.

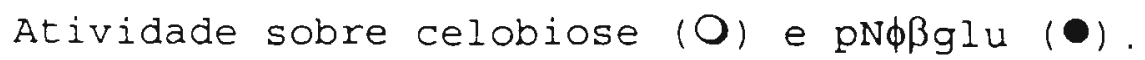


essa enzima é completamente estável a $60^{\circ} \mathrm{C}$ no tempo utilizado nesse ensaio. Quanto ao plote da atividade sobre pN $\phi \beta g l u$, temos uma curva que tende a um patamar em torno de $60 \%$ a partir de 40 minutos. Este resultado indica a presença de 2 formas enzimáticas. Uma delas inativa-se rapidamente perdendo toda atividade em torno de 40 minutos, enquanto a segunda enzima parece ser estável durante todo o tempo do experimento, sendo responsável pelo patamar após 40 minutos.

Em outro experimento de inativação térmica o material Q1 foi pré-incubado a $60^{\circ} \mathrm{C}$ por 40 minutos e então inativado a $65{ }^{\circ} \mathrm{C}$. Os resultados estão apresentados na figura 10B. O plote da atividade

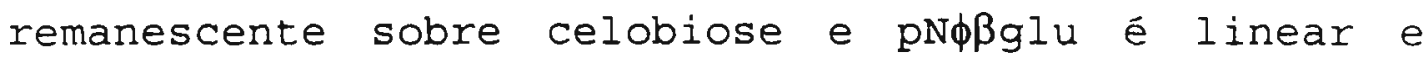
coincidente até 3 meias-vidas, sendo 34 minutos o valor de meia-vida. Este resultado indica que ocorre em Q1 uma forma enzimática ativa sobre celobiose e pN $\phi \beta g l u$ estável a $60^{\circ} \mathrm{C}$ por pelo menos 40 minutos.

O material Q2 também foi submetido a inativação térmica a $60^{\circ} \mathrm{C}$ para certificarmo-nos que a atividade sobre octilßglu é devida a uma só enzima. No plote do log da atividade remanescente versus tempo de inativação obteve-se uma reta com meia-vida de inativação de $70 \mathrm{~min}$ (figura 11), indicando que temos realmente uma só enzima neste material.

3.4 Caracterizą̧ão das $\beta$-glicosidases de Abracris flavolineata

3.4.1 Propriedades da celobiose-aril $\beta$-glucosidase 


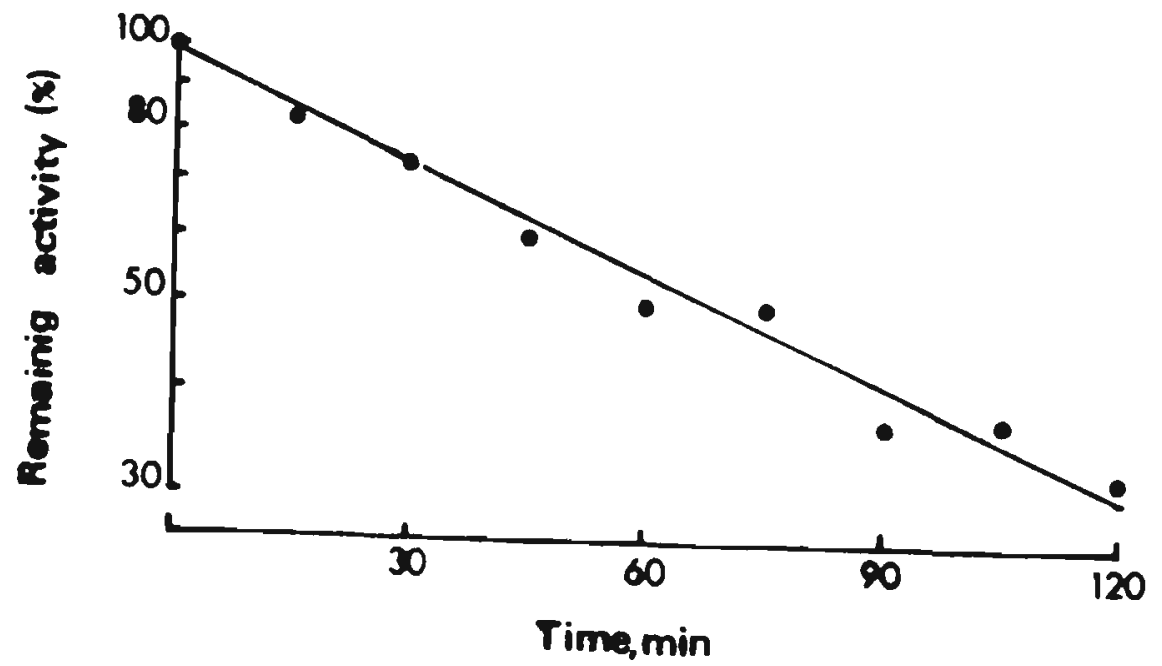

Figura 11 - Inativacão térmica a $60 \mathrm{C}$ das $\beta$-glicosidases presentes em Q2 (ver figura 6). Atividade sobre octilßglu. 
As propriedades da enzima eluída de Mono $Q$ ativa sobre celobiose e pN $\phi \beta g l u$ (figura 6) foram estudadas com o material Q1 incubado por 40 minutos a $60{ }^{\circ} \mathrm{C}$. Assim sabiamos estar trabalhando com apenas uma forma enzimática (ver resultados anteriores e item 3.3) que identificamos como celobiase-aril $\beta$ glucosidase.

- pH ótimo para esta enzima foi determinado com celobiose como substrato e obteve-se um valor de 5,5 (figura 12).

o efeito da concentração de diferentes substratos sobre a atividade enzimática também foi determinado. Os substratos usados foram celobiose, laminaribiose, pN $\phi \beta g l u$, salicina e arbutina. Sobre arbutina não foi encontrada atividade enzimática. A tabela 3 apresenta os Vmáx, $\mathrm{Km}$ e relação Vmáx/Km calculados para os diferentes substratos.

A enzima termoestável presente em Q1 é ativa

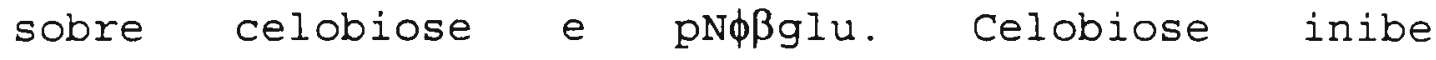
competitivamente a hiarólise de pN $\phi \beta g l u$ e vice versa (figura 13 e 14, respectivamente). Os valores de $\mathrm{Ki}$ obtidos foram 4,98 $\pm 0,04 \mathrm{mM}$ para o pN $\phi \beta g l u$ e $41 \pm 5$ mM para a celobiose (tabela 4).

Também foi usado como inibidor glicono $\delta$-lactona

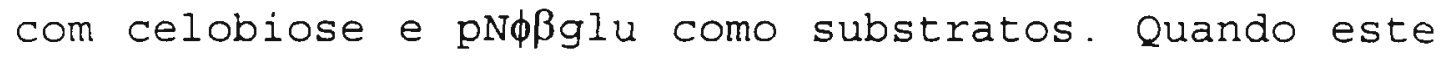
inibidor foi usado com celobiose, obteve-se um padrão de inibição competitivo linear simples (figura 15) e $\mathrm{Ki}$ é igual a $5,0 \pm 0,9 \mu \mathrm{M}$ (tabela 4). Já quando o substrato utilizado era o pN申ßglu o padrão de 


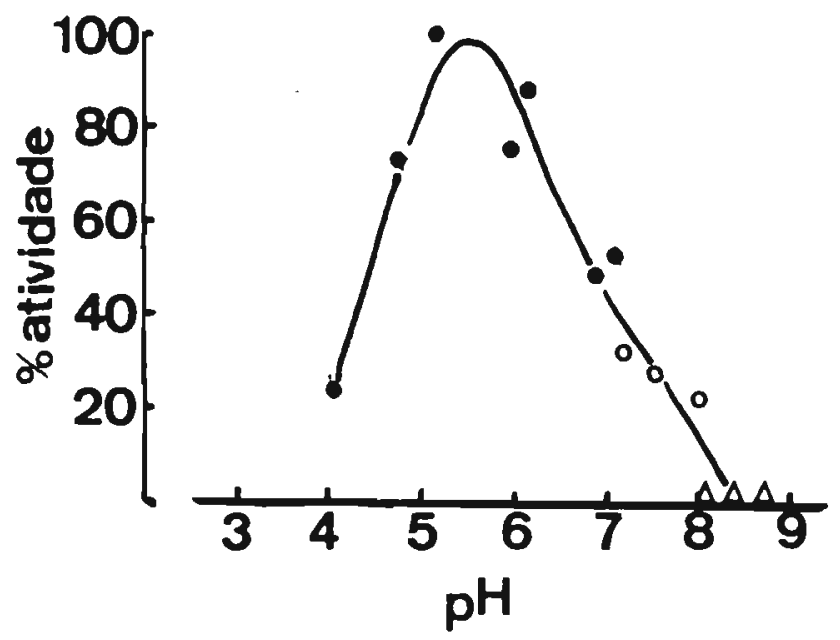

Figura 12 - Efeito do pH sobre a atividade da $\beta$-glicosidas termoestável presente em Q1. Atividade sobre celobiose. 1, tampão citrato-fosfato; (O), tampão fosfato; ( $\Delta$ ), tampão tris. 
Tabela 3 - Especificidade da celobiase-aril $\beta$-glucosidase intestinal de A. flavolineata para diferentes substratos

\begin{tabular}{|ccccc|}
\hline Substrato & $\mathrm{Km}(\mathrm{mM})$ & $\mathrm{Vm}(\mathrm{mU})$ & $\begin{array}{c}\mathrm{Vm} / \mathrm{Km} \\
(\mathrm{mU} / \mathrm{mM})\end{array}$ & $\begin{array}{c}\mathrm{Vm} / \mathrm{Km} \\
\text { Relativo }\end{array}$ \\
\hline Celobiose & $2,1 \pm 0,2$ & $2,52 \pm 0,01$ & $1,2 \pm 0,1$ & 100 \\
Laminaribiose & $3,6 \pm 0,4$ & $0,32 \pm 0,02$ & $0,08 \pm 0,01$ & 6,6 \\
pNoßglu & $0,4 \pm 0,1$ & $0,04 \pm 0,005$ & $0,1 \pm 0,03$ & 8,3 \\
Salicina & $2,9 \pm 0,1$ & $0,0274 \pm 0,0007$ & $0,0094 \pm 0,0004$ & 0,7 \\
Arbutina & - & $<0,003$ & - & - \\
\hline
\end{tabular}

Foi utilizado $\circ$ material Q1 previamente aquecido a $60^{\circ} \mathrm{C}$ por 30 minutos. Dados obtidos a partir da incubação deste material com 10 diferentes concentrações de cada substrato listado acima preparados em tampão citrato-fosfato $50 \mathrm{mM} \mathrm{pH} \mathrm{6,0.} \mathrm{Os} \mathrm{parâmetros}$ cinéticos foram determinados (média e desvio padrão da média) com utilização do software Enzfitter. 


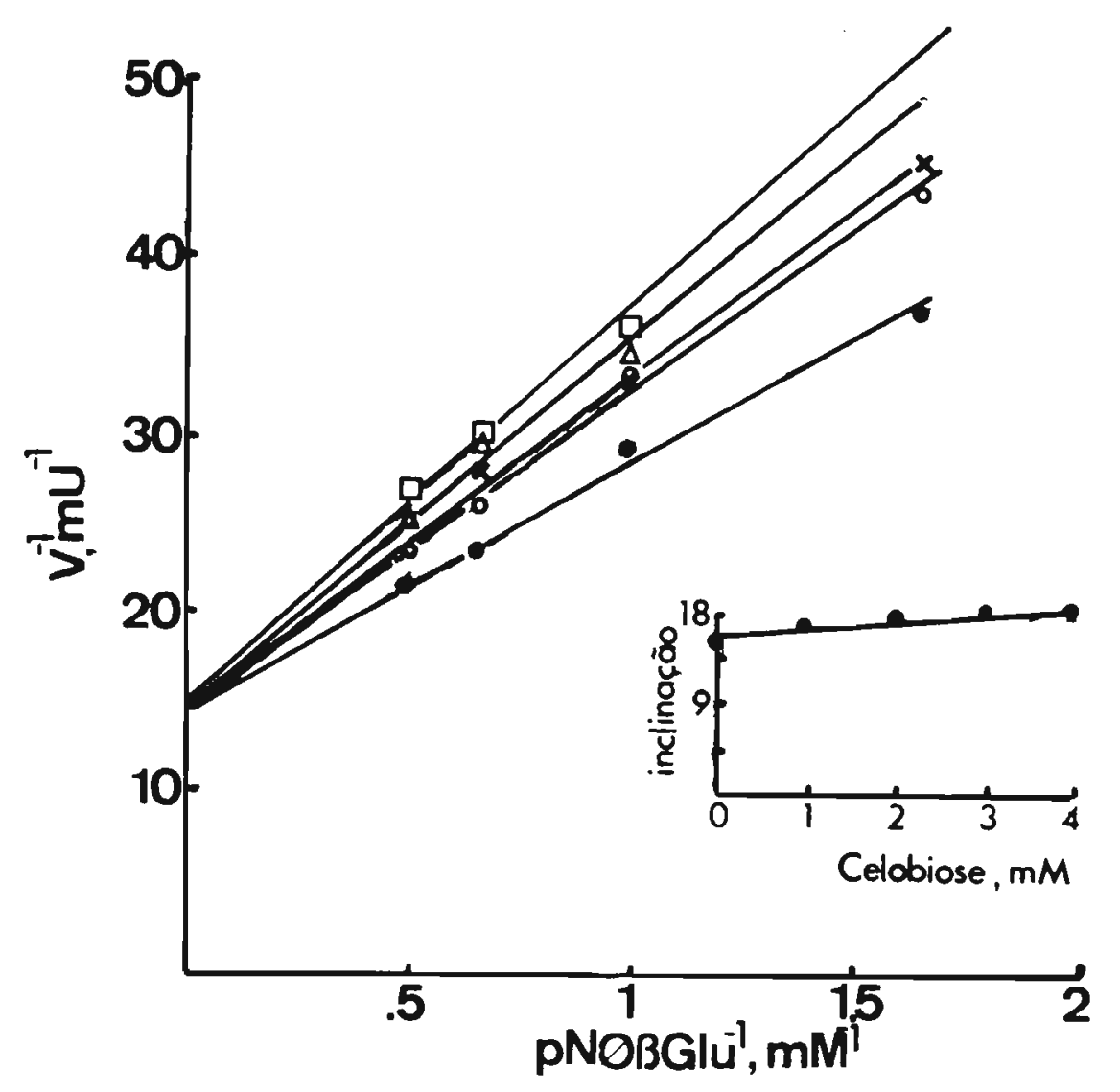

Figura 13 - Competição de substratos da $\beta$-glicosidase

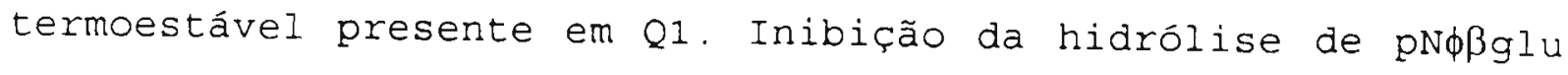
por celobiose. Os plotes de Lineweaver-Burk forma feitos para diferentes concentrações de substrato em cada concentração fixa do substrato-inibidor. Inserção: replote das inclinações calculadas dos plotes de Lineaweaver-Burk versus a concentração do substrato-inibidor. 


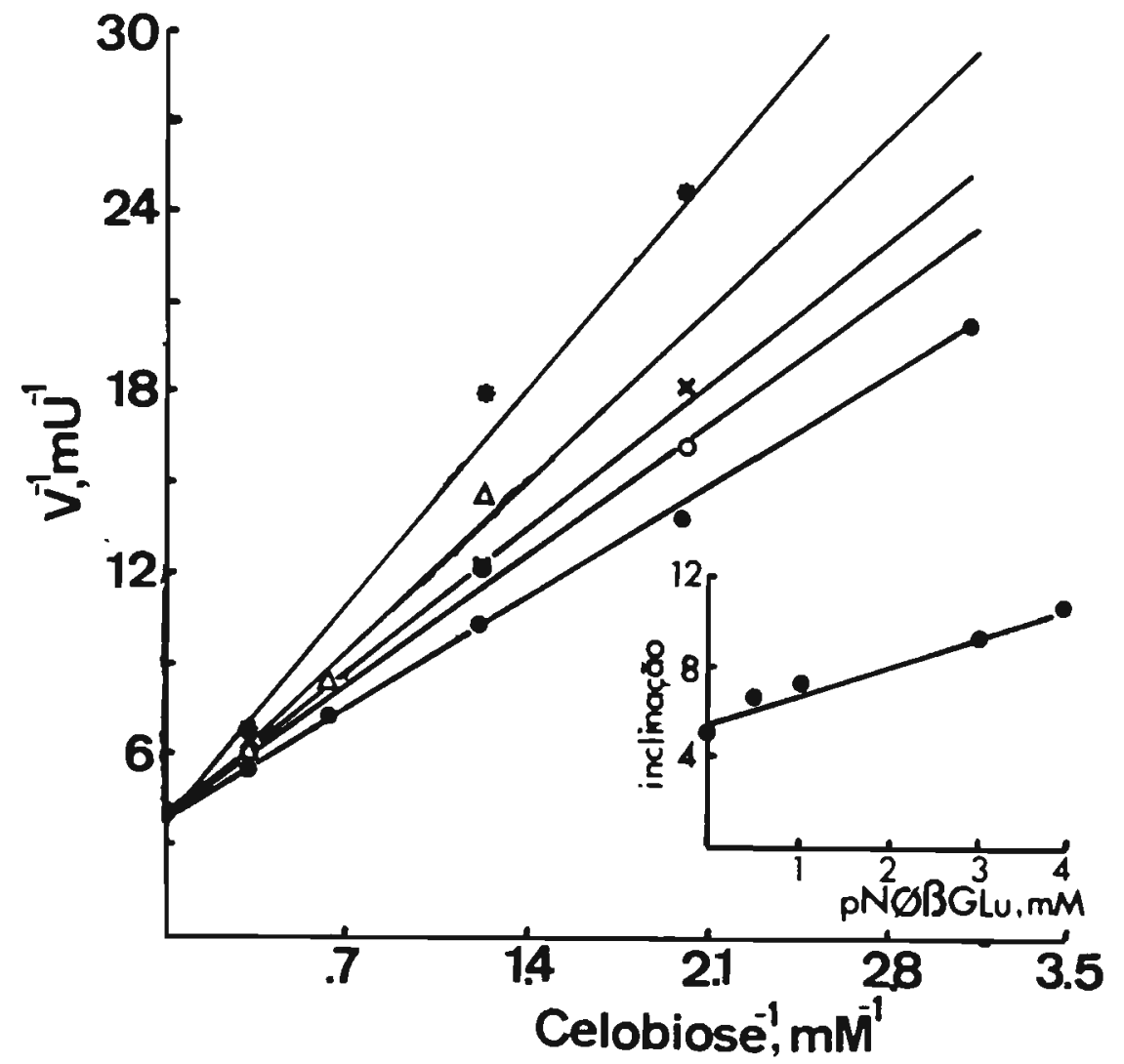

Figura 14 - Competição de substratos da $\beta$-glicosidase presents em Q1. Inibição da hidrólise de celobiose por pNфßglu. CE plotes de Lineweaver-Burk foram feitos para diferente concentrações de substrato em cada concentração do substratoinibidor. Inserção: replote das inclinações calculadas dos plotes de Lineaweaver-Burk versus a concentração do substrat= inibidor. 
Tabela 4 - Inibição da celobiase-aril $\beta$-glucosidase intestinal de A.flavolineata

\begin{tabular}{|c|c|c|}
\hline Substrato & Inibidor & $\mathrm{Ki} \quad(\mathrm{mM})$ \\
\hline Celobiose & pN $\phi \beta g l u$ & $4,98 \pm 0,07$ \\
\hline pN $\phi \beta g l u$ & celobiose & $41 \pm 9$ \\
\hline Celobiose & glucono $\delta$-lactona & $0,005 \pm 0,0003$ \\
\hline pN $\phi \beta g I u$ & glucono $\delta$-lactona & $0,042 \pm 0,007$ \\
\hline $\mathrm{pN} \phi \beta \mathrm{glu}$ & $\gamma$ galactona lactona & não inibe \\
\hline
\end{tabular}

O material enzimático usado foi Q1 previamente aquecido a $60^{\circ} \mathrm{C}$ por 30 min. Este material foi incubado com 5 diferentes concentrações de inbidor para cada uma das 5 concentrações dos substratos preparados em tampão citrato-fosfato $50 \mathrm{mM} \mathrm{pH} 6,0$. As inibições ( exceto glucono $\delta$-lactona versus pN $\phi \beta g l u$ ) apresentam um padrão competitivo linear simples. Glucono $\delta$ lactona é um inibidor não competitivo linear simples. 


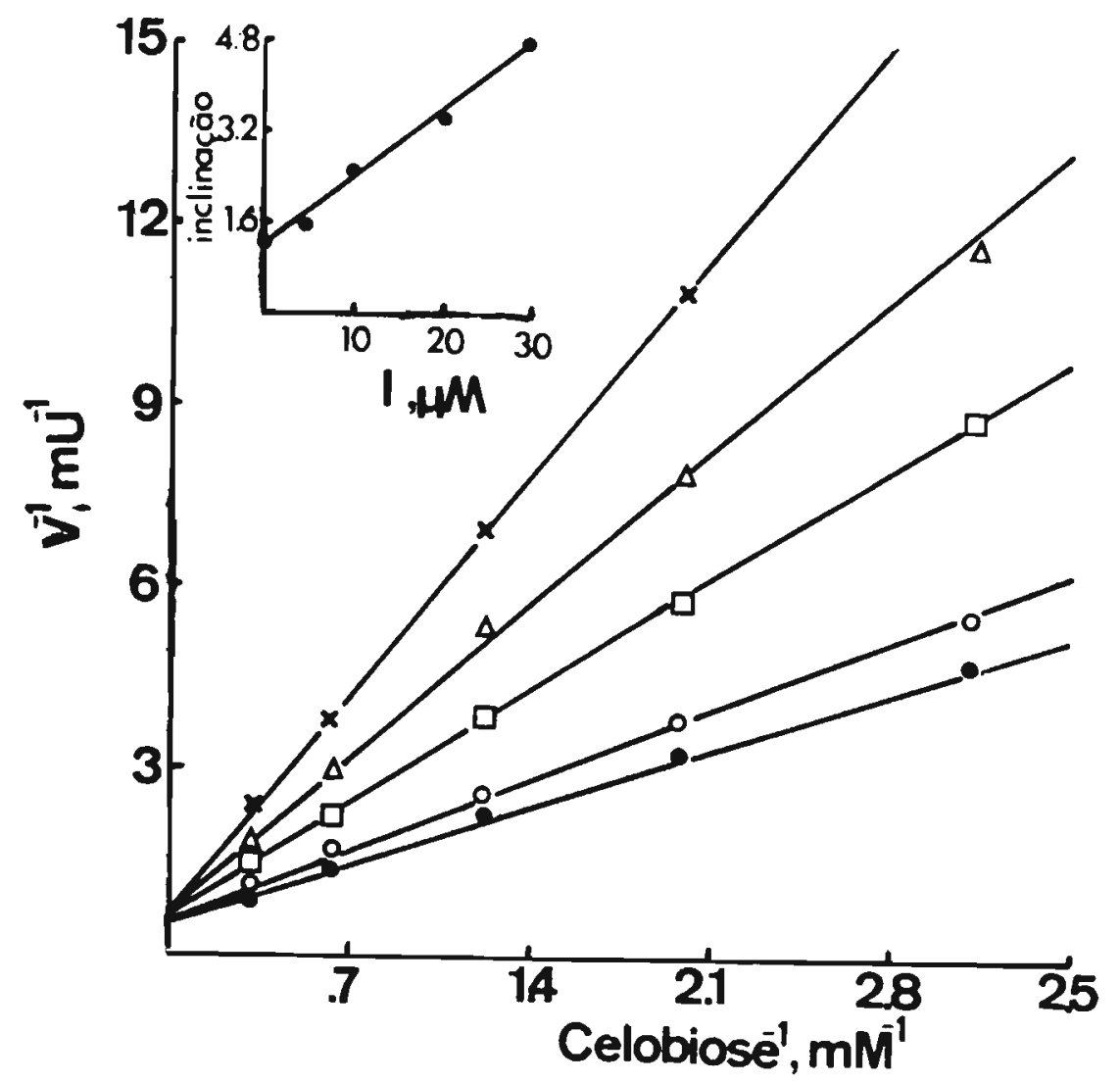

Figura 15 - Inibição da hidrólise de celobiose pela $\beta$ glucosidase termoestável presente em Q1 por glucono $\delta$-lactona . Plotes de Lineweaver-Burk foram feitos para diferentes concentrações de inibidores. Inserção: replote das inclinações calculadas dos plotes de Lineaweaver-Burk versus concentração do inibidor. 
inibição era não-competitivo linear simples (figura 16) com um $\mathrm{Ki}$ de $42 \pm 7 \mu \mathrm{M}$.

\subsubsection{Propriedades da alquil $\beta$-glucosidase}

Para estudo das propriedades da enzima ativa

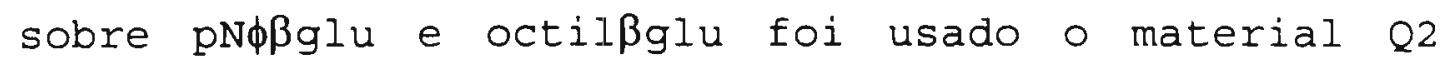
eluído de Mono Q (figura 6), quando o substrato era octilßglu. Quando pN $\phi \beta g l u$ era usado como substrato o material Q2 era submetido a eletroforese e as frações 33 a 35 eram reunidas (figura 7), pois, como mencionado anteriormente a fração Q2 está contaminada pela Eração Q1.

Um pH ótimo de 4,8 foi determinado utilizando-se octilßglu como substrato (figura 17).

Estudando o efeito da concentração de substrato (octilßglu) na atividade enzimática foi observado que - plote de $\mathrm{V} \quad \mathrm{X}$ [S] resultava numa curva aproximadamente sigmoidal (figura $18 \mathrm{~A}$ e B) e não em uma hipérbole, característica de enzimas Michaelianas. O mesmo resultado foi obtido utilizando hexil, heptil, nonil, decil e undecilßglu. Este resultado poderia ser explicado se a $\beta$-glucosidase em questão fosse uma enzima de múltiplos sítios entre os quais houvesse cooperatividade. Outra possibilidade seria o substrato agir também como um ativador, Iigando-se a um sítio distinto do sítio ativo. o resultado também ficaria explicado se as moléculas de substrato, que são anfipáticas, estivessem formando micelas e somente estas fossem o substrato da enzima e não o monômero. Entretanto, esta última hipótese pode ser descartada, já que todas as concentrações de 

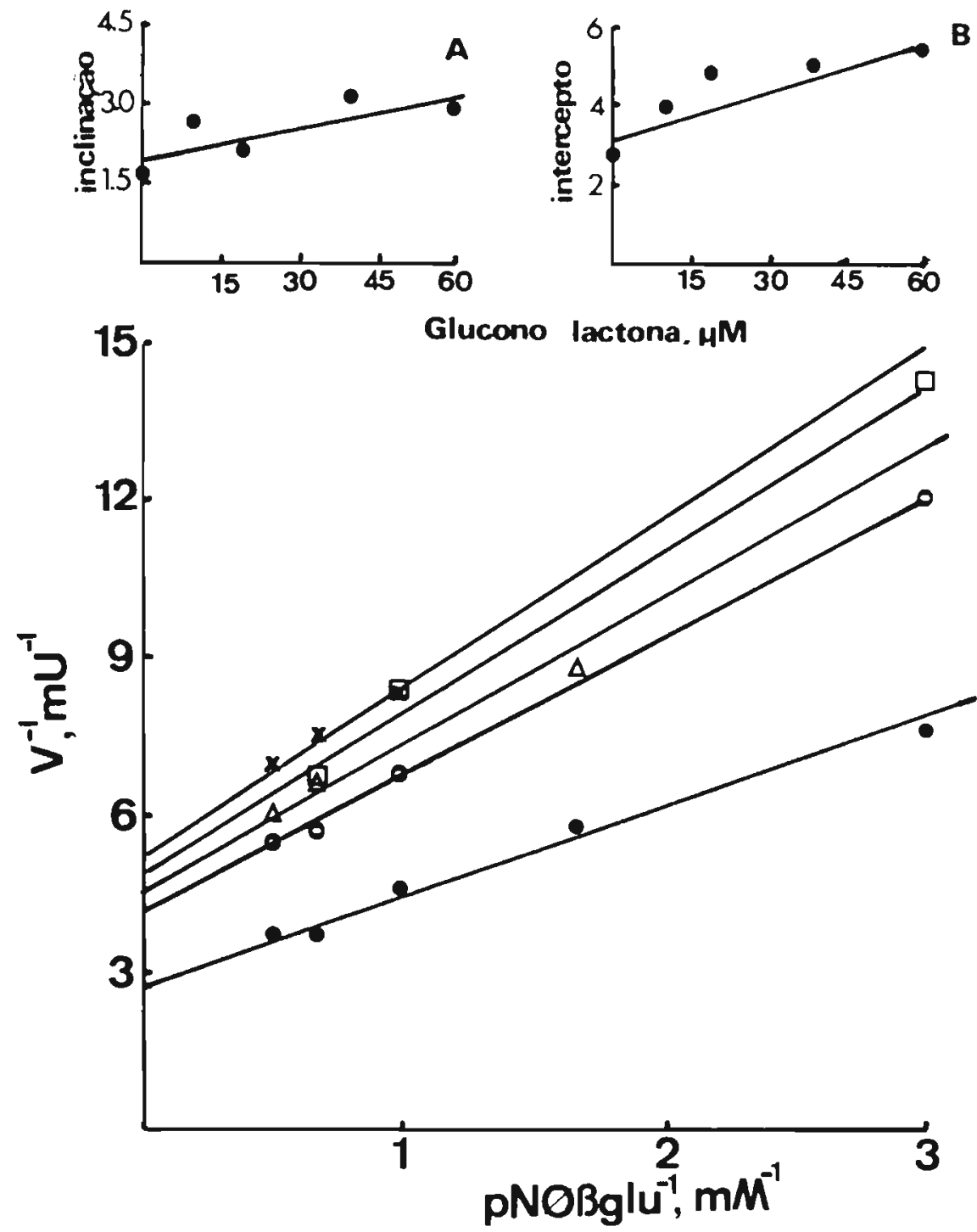

Figura 16 - Inibição da hidrólise de pNфßglu pela $\beta$ glucosidase presente em Q1 por glicono $\delta$-lactona. Plotes de Lineawever-Burk foram feito para diferentes concentrações de inibidores. Inserção: A) replote das inclinações calculadas dos plotes de Lineweaver-Burk versus concentração de inibidor, B) replote dos interceptos calculados dos plotes de 


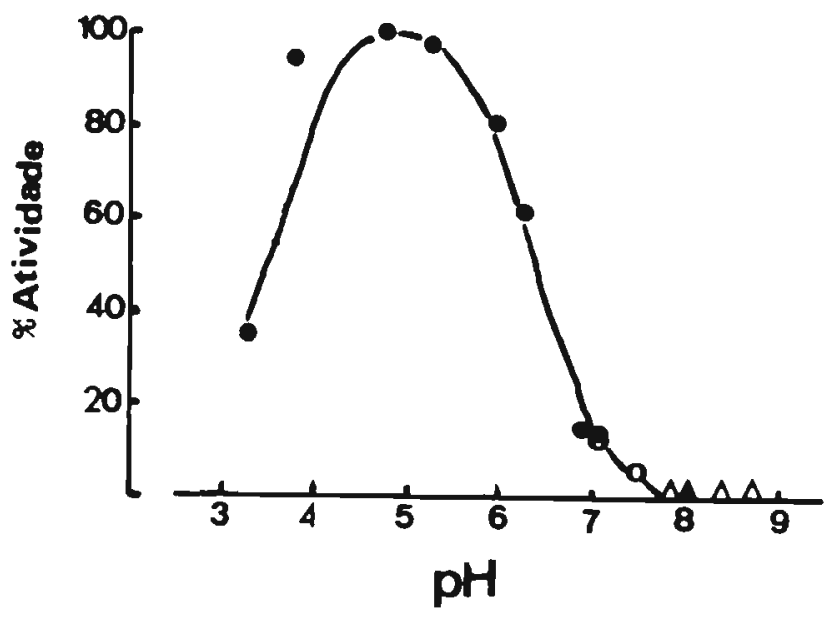

Figura 17 - Efeito do $\mathrm{pH}$ na atividade sobre octilßglu da $\beta$ glicosidase presente em Q2. (•), tampão citrato-fosfato; 10 ), tampão fosfato; $(\Delta)$, tampão tris. 
substrato usadas são menores que a CMC dos respectivos alquilßglu.

$\mathrm{Na}$ tentativa de esclarecer esse resultado, o efeito da concentração de octillßglu na velocidade da reação enzimática foi estudado na presença de Triton $\mathrm{X}-1002,4 \mathrm{mM}(10 \mathrm{CMC})$. Nestas condições o plote $\mathrm{V} x$ [S] resultou em uma hipérbole (figura 18A), indicando que a enzima é Michaelina e não possui múltiplos sítios para o substrato. Isto é confirmado pelo plote linear dos duplos recíprocos (figura 18C).

Utilizando a enzima eletroforeticamente purificada a partir de $\mathrm{Q} 2$ foi também determinado 0

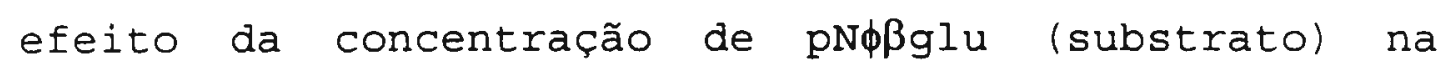
atividade enzimática (figura 19A). Como pode ser visto, o plote $\mathrm{V} \times$ [S] resulta em uma hipérbole. Isto indica que este substrato não atua como ativador, talvez por não possuir uma porção suficientemente hidrofóbica. A partir destes resultados foi determinado o Vmáx e Km para este substrato (tabela 5).

Assumindo que a sigmóide apresentada na figura $18 \mathrm{~A}$ resulta da ativação da enzima pelo próprio substrato (octilßglu), esta curva pode ser descrita pela equação (Segel, 1975):

$$
\mathrm{V}=\frac{\operatorname{Vmáx} \cdot \mathrm{S} \cdot(1+\beta \cdot \mathrm{A} / \alpha \mathrm{Ka})}{\mathrm{Km} \cdot(1+\mathrm{A} / \mathrm{Ka})+\mathrm{S} \cdot(1+\mathrm{A} / \alpha \mathrm{Ka})}
$$

Onde $v=$ velocidade inicial (mU), Vmáx= velocidade máxima (mU), $S=$ concentração de substrato $(m M), \beta=$ fator pelo qual a ligação do ativador afeta 

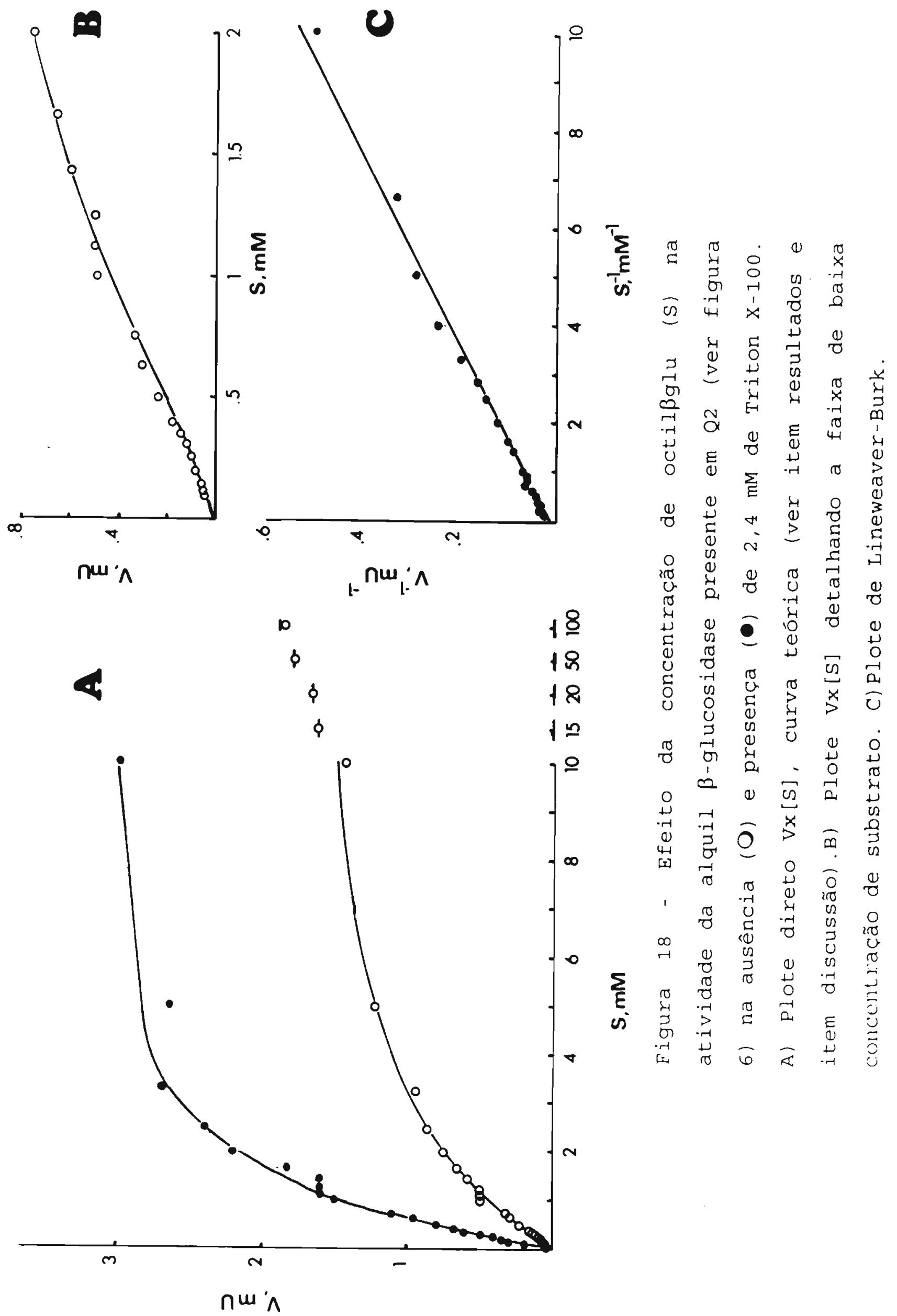


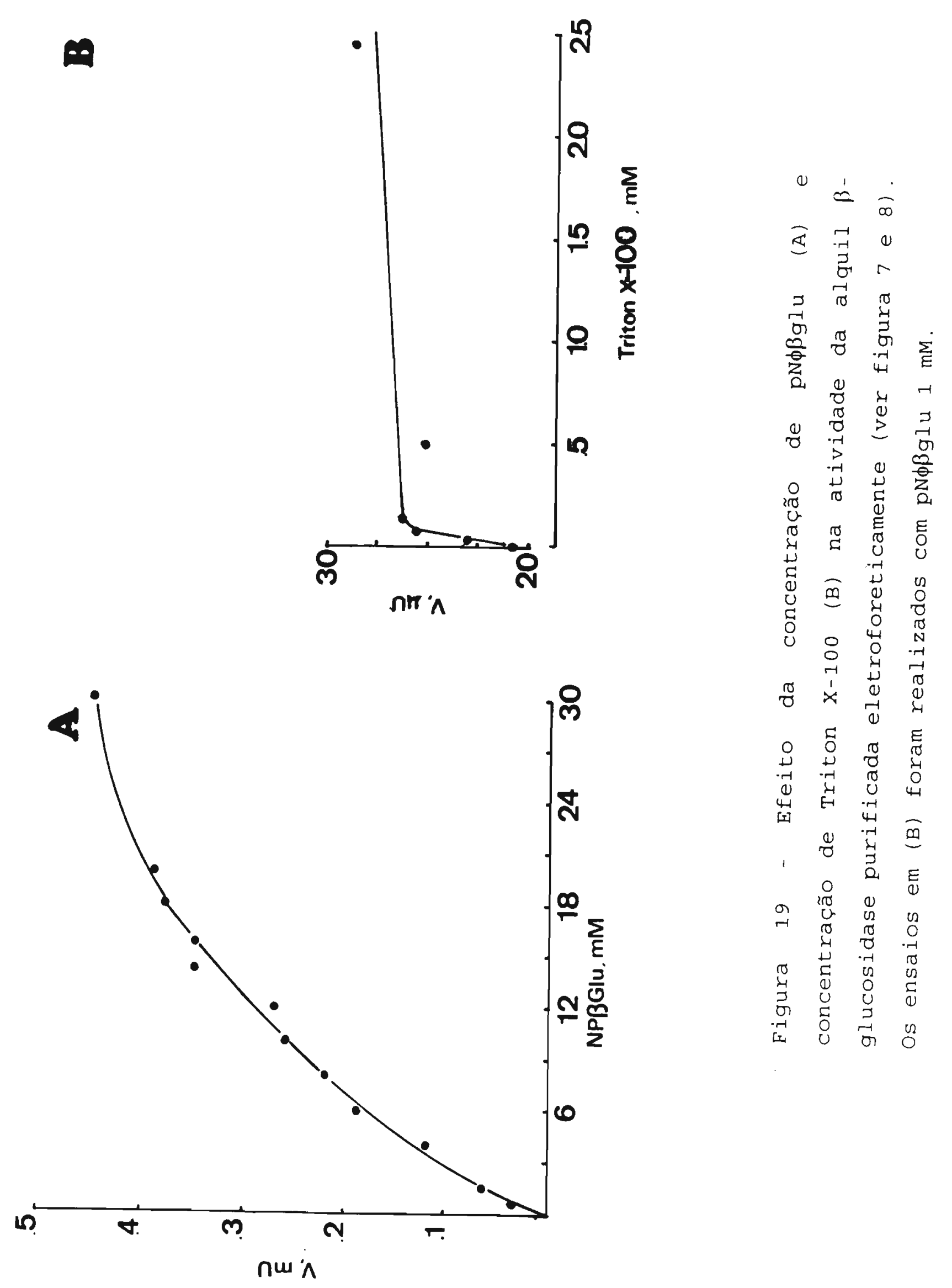


Tabela 5 - Parâmetros cinéticos da alquil $\beta$-glucosidase intestinal de $\underline{A}$. flavolineata na ausência de Triton $\mathrm{x}-100$.

\begin{tabular}{|c|c|c|c|c|c|c|}
\hline Substrato & $\mathrm{Vm}(\mathrm{mU})$ & $\mathrm{Rm}$ & $(m M)$ & $\mathrm{Ra}(\mathrm{mM})$ & $\alpha$ & $\beta$ \\
\hline OctilßgIu & 1.5 & & 4 & 1.0 & 0,6 & 1,3 \\
\hline $\mathrm{pN} \phi \beta g l u$ & $0,728 \pm 0,003$ & 1,7 & $\pm 0,2$ & - & - & - \\
\hline
\end{tabular}

Os parâmetros cinéticos com octilßglu e pN $\phi \beta g l u$ foram calculados a partir dos dados apresentados nas figuras 18A e 19A, respectivamente. 
a constante catalítica, $\mathrm{A}=$ concentração do ativador $(\mathrm{mM}), \mathrm{Km}=$ constante de Michaelis (mM), $\alpha$ = fator pelo qual a ligação do ativador afeta $\circ \mathrm{Km} e \mathrm{Ka}=$ constante de dissociação do complexo enzima-ativador $(\mathrm{mM})$.

Utilizando esta equação e os dados experimentais apresentados na figura 18A foi possivel calcular uma curva teórica de $\mathrm{V} \times$ [S] para a reação da alquil $\beta$ glucosidase (figura $18 \mathrm{~A}$ e $\mathrm{B}$ ) e os respectivos parâmetros cinéticos (tabela 5). Para simulação da sigmóide teórica era necessário determinar $\circ \mathrm{Km}$ e Vmáx. Deste modo o número de incógnitas na equação ficava reduzido, o que possibilita a obtenção de valores mais confiáveis. Os valores de $\beta$ Vmáx e $\alpha \mathrm{Km}$ foram conseguidos através da linearização do segmento final (concentrações de $\mathrm{S}$ de 2 a $20 \mathrm{~mm}$ ) da sigmóide experimentalmente obtida. Nestes cálculos foi utilizado 0 software Enzfitter (Enzfitter, Leatherbarrow R.J., Elsevier, Biosoft, 1987).

Para verificar se a diferente cinética de

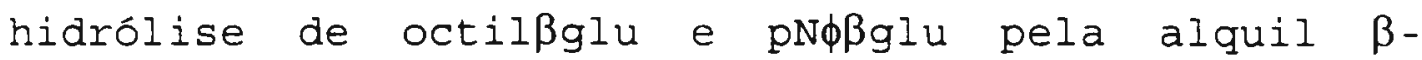
glucosidase, seria devido a existência de dois sitios ativos diferentes, foram realizados experimentos de competição entre os substratos utilizando octilßglu e pN $\phi \beta g l u$ (figura $20 \mathrm{~A}$ e $\mathrm{B}$ ). Os resultados indicam que essas substâncias são hidrolisadas no mesmo sitio, pois os valores de $\mathrm{Ki}$ e $\mathrm{Km}$ são semelhantes entre si para cada um deles (comparar tabela 5 e 6).

Na tentativa de melhor caracterizar a ativação da alquil $\beta$-glucosidase por Triton $x-100$, estudou-se 0 

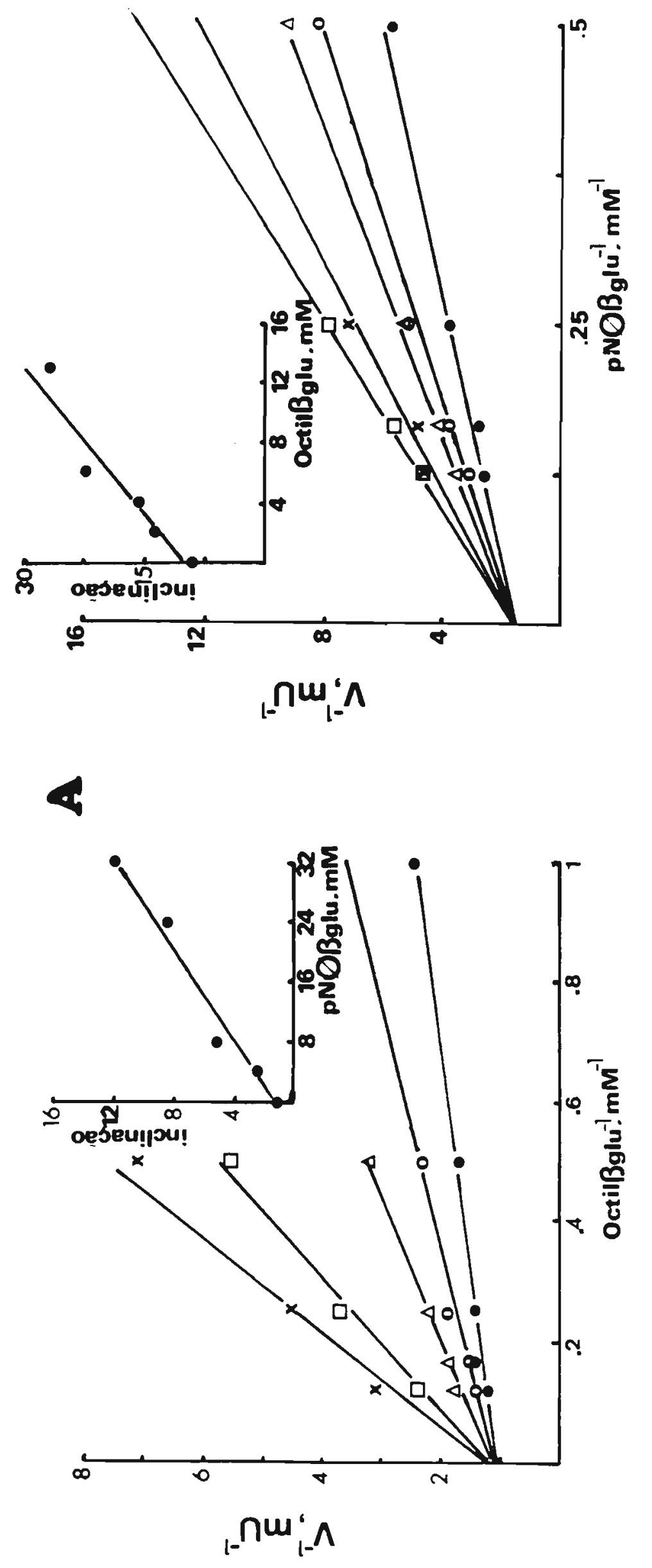

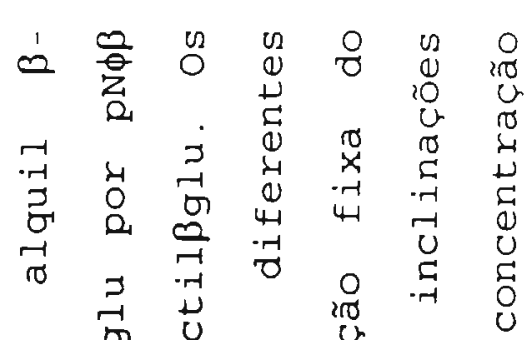

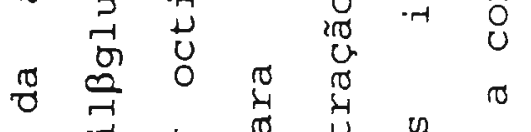

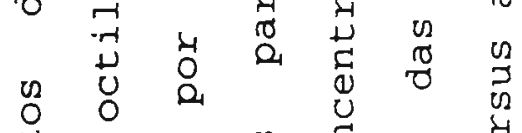

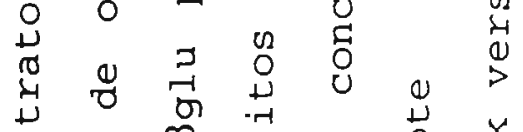

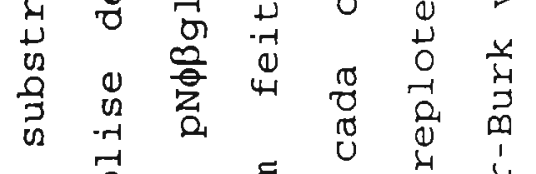

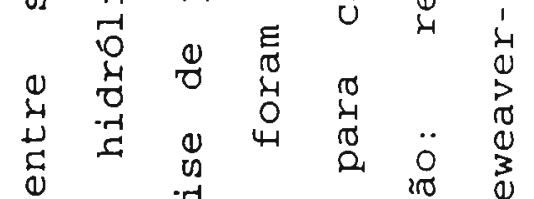

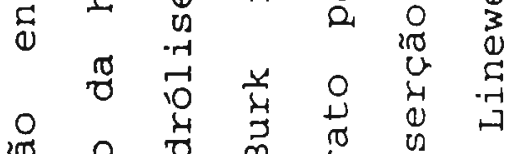

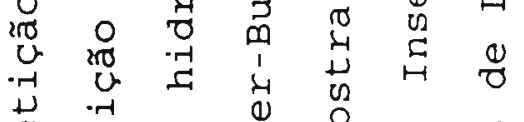

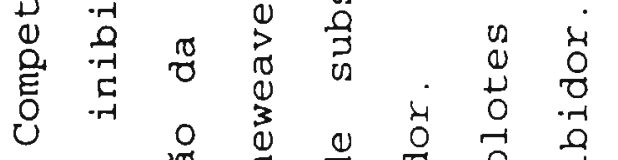

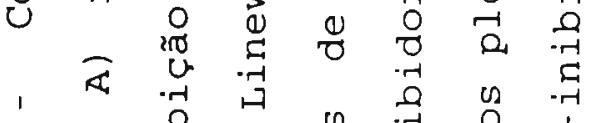

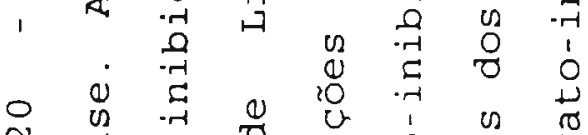

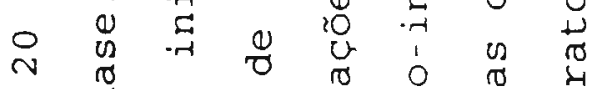

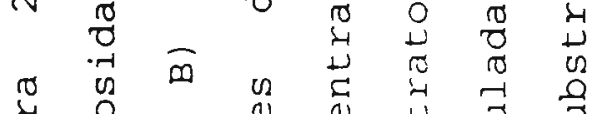

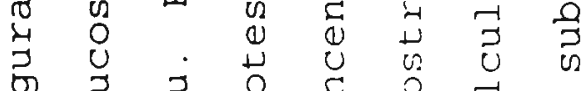

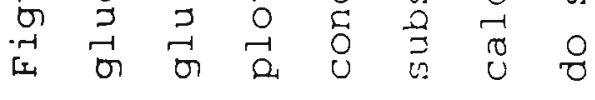


Tabela 6 - Inibição da alquil $\beta$-glucosidase intestinal de $\underline{A}$. Elavolineata

\begin{tabular}{|c|c|c|}
\hline Substrato & Inibidor & $\mathrm{Ki} \quad(\mathrm{mM})$ \\
\hline Octil $\beta g l u$ & $\mathrm{pN} \phi \beta g l u$ & $3,6 \pm 0,2$ \\
\hline $\mathrm{pN} \phi \beta g I u$ & Octilßglu & $4,7 \pm 0,2$ \\
\hline Octilßglu & Glucono $\delta$-lactona & $0,05 \pm 0,004$ \\
\hline
\end{tabular}

Foi utilizada a alquil $\beta$-glucosidase purificada eletroforeticamente a partir de Q2. Este material foi incubado com 5 diferentes concentrações de inibidor em cada uma das 5 diferentes concentrações dos substratos usados. Os substratos foram preparados em tampão citrato-fosfato $50 \mathrm{mM} \mathrm{pH} 6,0$ contendo Triton X-100 2,4 mM. Todas as inibições apresentam um padrão competitivo linear simples. 
efeito de diferentes concentrações do ativador sobre a atividade enzimática (figura 19B). Observa-se que a enzima é totalmente ativada por Triton X-100 em concentrações submicelares ( $C M C=0,24 \mathrm{mM})$. Assim aparentemente a alquil $\beta$-glucosidase liga-se a monômeros do detergente. Investigou-se se a enzima também seria capaz de ligar-se a micelas de Triton X100 realizando-se filtração em gel do material Q2 em coluna de Superose 12 na presença e ausência de Triton X-100 0,21 mM $(0,9 \mathrm{CMC})$ e $4,8 \mathrm{mM}(20 \mathrm{CMC})$. Nas três situações a atividade enzimática sobre octilßglu foi eluída no mesmo volume, indicando que a enzima não havia se ligado às micelas. A ligação da enzima a uma micela de Triton $\mathrm{X}-100$ teria alterado o valor do Mr de 82.000 para cerca de 170.000 .

o efeito do número de carbonos no radical alquil do substrato sobre a atividade enzimática foi estudado através da determinação do Vmáx, $\mathrm{Km}$ e a relação Vmáx/Km para alquil $\beta$-glucosídeos que apresentavam de 6 a 11 carbonos no aglicone hidrofóbico. Os resultados estão apresentados na tabela 7. Também foi utilizado metilßglu como substrato, embora nenhuma atividade enzimática tenha sido detectada sobre o mesmo.

A alquil $\beta$-glucosidase é fortemente inibida de modo competitivo (figura 21) por glicono $\delta$-lactona $(\mathrm{Ki}=0,05 \pm 0,04 \mathrm{mM})($ tabela 6$)$.

Finalmente, determinou-se qual a configuração anomérica da glicose liberada a partir do octilßglu pela ação da alquil $\beta$-glucosidase. O resultado 
Tabela 7 - Especificidade por diferentes substratos da alquil $\beta$ glicosidase intestinal de A. Elavolineata.

\begin{tabular}{|c|c|c|c|c|}
\hline substrato & $\mathrm{Rm}(\mathrm{mM})$ & $V m(m U)$ & $\begin{array}{c}\mathrm{Vm} / \mathrm{Km} \\
(\mathrm{mU} / \mathrm{mM})\end{array}$ & $\begin{array}{c}\mathrm{Vm} / \mathrm{Km} \\
\text { Relativo }\end{array}$ \\
\hline Metilßglu & - & $<0,05$ & - & - \\
\hline Hexilßglu & $4,1 \pm 0,1$ & $2.9 \pm 0.1$ & $0.7 \pm 0.03$ & 70 \\
\hline Heptilßglu & $3,0 \pm 0,2$ & $2,66 \pm 0,02$ & $0,88 \pm 0,05$ & 88 \\
\hline octilßglu & $2,9 \pm 0,1$ & $2,64 \pm 0,08$ & $0,91 \pm 0,05$ & 91 \\
\hline Nonilßglu & $2,2 \pm 0,2$ & $2,3 \pm 0,1$ & $1,0 \pm 0,1$ & 100 \\
\hline Decilßglu & $2,0 \pm 0,1$ & $1,71 \pm 0,02$ & $0,85 \pm 0,05$ & 85 \\
\hline Undecilßglu & $3,3 \pm 0,1$ & $0,70 \pm 0,02$ & $0,21 \pm 0,01$ & 21 \\
\hline
\end{tabular}

Foi utilizado como fonte enzimática o material Q2. Este foi incubado com 10 diferentes concentrações de cada substrato acima Iistado. Os substratos foram preparados em tampão citratofosfato $50 \mathrm{mM} \mathrm{pH} 6,0$ contendo $2,4 \mathrm{mM}$ de Triton $\mathrm{X}-100$. 


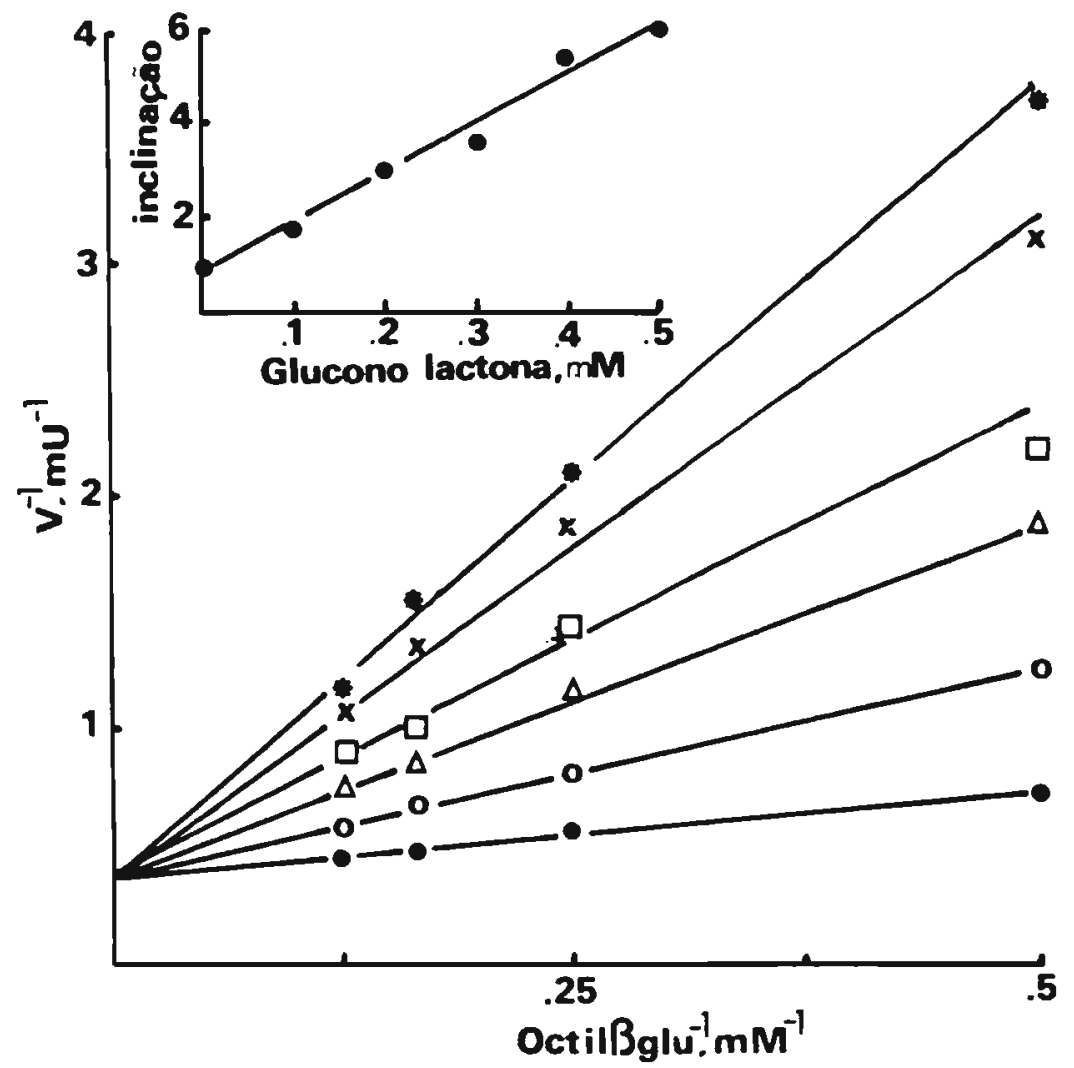

Figura 21 - Inibição por glicono $\delta$-lactona da alquil $\beta$ glucosidase. Plotes de Lineweaver-Burk foram feitos para diferentes concentrações de substrato para cada concentração fixa do inibidor. Inserção: replote das inclinações calculadas dos plotes de Lineweaver-Burk versus a concentração do inibidor. 
apresentado na figura 22 indica que a reação enzimática ocorre com retenção de configuração, ou seja, é liberada $\beta$-D-glicose. 


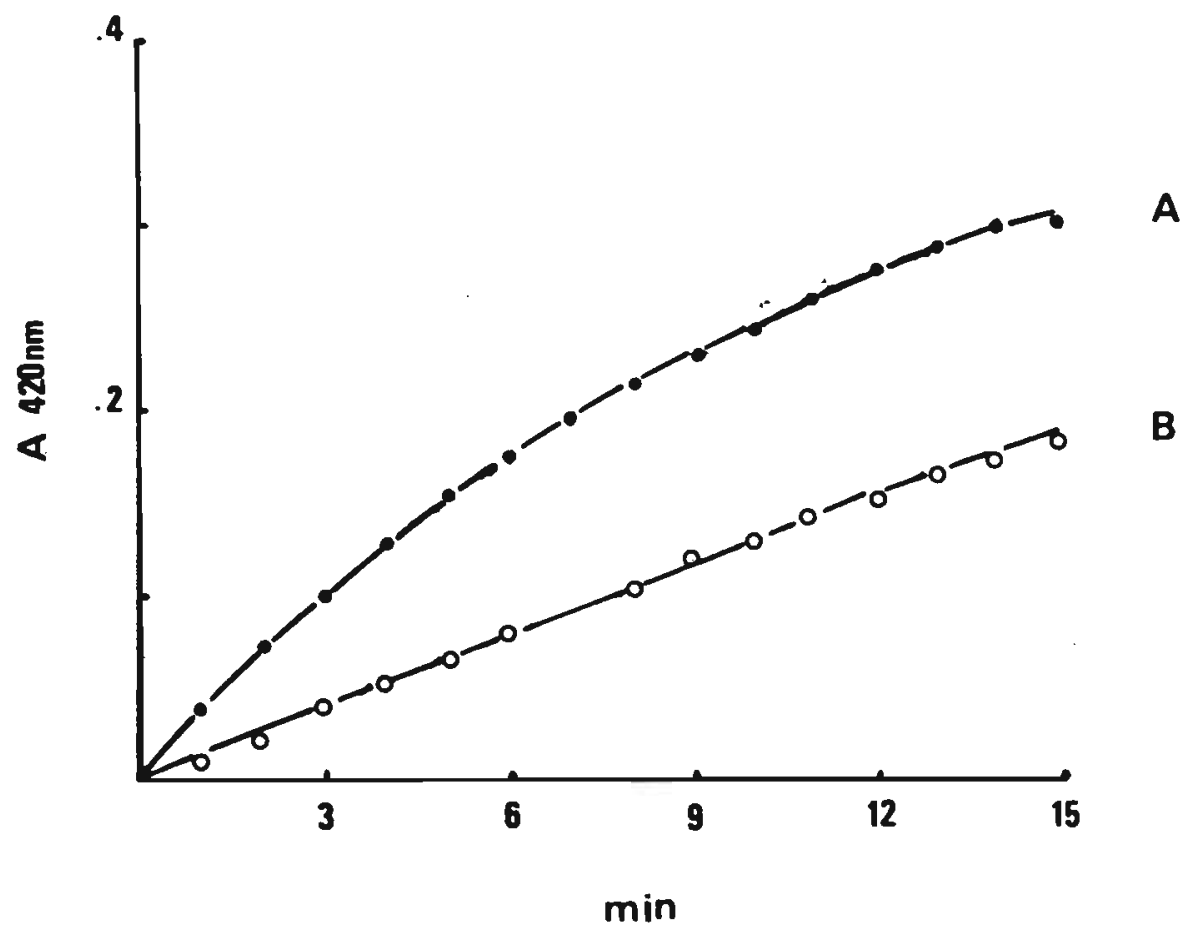

Figura 22 - Identificação enzimática da configuração anomérica da D-glicose liberada pela alquil Bglucosidase. A) D-glicose liberada pela alquil $\beta$-glucosidase. B) controle com $\alpha-E$ glicose . Após a anomerização (fervura), as curvás experimentais e controle tornam-se coincidentes com a curva $F$ A concentração de glicose e outras condições experimentais são idênticas para as curvas $A$ e B. Detalhes em Materiais e métodos. 


\section{4 - DISCUSSÃo}

\subsection{Determinação da distribuição subcelular de} enzimas digestivas e seus mecanismos de secreção

Como os gafanhotos apresentam um comportamento alimentar influenciado por vários fatores, é possível que alterações neste comportamento levasse a alterações na secreção das enzimas digestivas.

Para verificar se o tempo decorrido após uma refeição influenciava na produção de grânulos de secreção com enzimas digestivas, um experimento foi realizado no qual os animais permaneceram em jejum por 24 horas, em seguida foram alimentados por 20 minutos e então dissecados após diferentes intervalos de tempo $(0,1,3$ e 5 horas $)$ e os cecos anteriores submetidos a fracionamento celular. Os resultados mostram que o tempo decorrido após a refeição altera a distribuição subcelular das enzimas digestivas (figura 2). Cerca de 3 horas após a refeição há um maior enriquecimento de várias enzimas digestivas na fração onde devem ser recuperados os grânulos de secreção. É possível que a refeição tenha atuado como um estímulo para produção de enzimas digestivas que estão sendo secretadas por meio de exocitose.

Observando ainda a figura 2 notamos que quando é utilizado pN $\phi \beta g l u$ como substrato, a distribuição subcelular da atividade enzimática é aproximadamente constante ao longo do tempo após a refeição. Isto talvez signifique que a enzima responsável pela hidrólise desse substrato seja secretada constitutivamente, ou seja, a refeição não estimula 
sua produção. Ou ainda, a indução da produção da enzima digestiva responsável pela hidrólise do pN $\phi \beta$ glu ocorreria em tempos muito curtos ou muito longos após a refeição não sendo, por isso, detectada em nosso experimento.

Uma vez que nosso objetivo principal era encontrar uma fração subcelular rica em grânulos de secreção, animais tratados como descrito anteriormente tiveram seus cecos anteriores removidos e submetidos a um fracionamento celular 3 horas após a refeição.

Observando os resultados da distribuição subcelular de tripsina, notamos que ela acompanha a distribuição da LDH, que é uma enzima citossólica (figura 3). A presença quase exclusiva de atividade no sobrenadante final indicaria que a tripsina está solúvel no citoplasma celular. Desse modo, sua secreção deveria ocorrer por um mecanismo do tipo holócrino ou apócrino. Porém uma inspeção na ultraestrutura das células do intestino médio de $\underline{A}$. flavolineata não indica nenhum desses tipos de secreção (resultados não publicados). Uma vez que tripsina é encontrada predominantemente nos espaços luminais do inseto (Ferreira et al, 1990), o mais provável é que a enzima presente na fração solúvel celular corresponda ao material presente no fluido dos cecos que não foi removido nas lavagens ou a enzimas adsorvidas ao glicocálix celular. Durante a homogeneização, o glicocálix seria fragmentado e essas enzimas seriam liberadas para a solução. 
Situação semelhante parece ocorrer em Tenebrio molitor (Coleoptera) (Ferreira et al, 1990). Neste Coleoptera, Ferreira et al. (1990) demonstraram que alimentando-se o animal com um corante não absorvível, o mesmo era recuperado na fração solúvel celular. Como o corante não era absorvido pelas células, foi proposto que esse material deveria corresponder ao corante preso ao glicocálix. Deve-se ressaltar que a adsorção de enzimas ao glicocálix de enterócitos já foi comprovada em mamíferos (Ugolev et al, 1986). Além disso, há uma série de enzimas em insetos que parecem ocorrer ligadas ao glicocálix (ver Terra \& Ferreira, 1994).

A amilase, maltase, pNфßglu hidrolase são recuperadas enriquecidas nas frações solúveis dos precipitados. Este resultado pode indicar que estas enzimas ocorram solúveis no interior de grânulos de secreção.

Tanto aminopeptidase como dipeptidase são recuperadas nos sobrenadantes e nos precipitados, indicando que podem apresentar uma forma solúvel e uma ligada a membrana. Isso realmente deve ocorrer porque homogeneizados realizados em água e centrifugados a $100.000 \mathrm{xg}$ por $1 \mathrm{~h}$ mostraram atividade de aminopeptidase (Ferreira et al, 1990b) e dipeptidase (resultados não publicados) no sedimento.

A atividade de aminopeptidase, amilase, maltase e da hidrolase de pNфßglu recuperadas na fração solúvel celular também devem corresponder a enzimas frouxamente adsorvidas ao glicocálix. Apóia essa 
hipótese o fato dessas enzimas serem encontradas nos espaços luminais de $\underline{A}$. Elavolineata e que não tem, aparentemente, uma função intracelular. Somente a dipeptidase poderia ter uma função intracelular, uma vez que é possivel que ocorra absorção de pequenos peptídeos de modo análogo ao que ocorre em mamíferos (Ugolev et al, 1990).

Observando a figura 3 nota-se que a atividade de SDH é estranhamente alta nas frações solúveis de precipitados, resultado semelhante foi observado em fracionamentos subcelulares do epitélio ventricular da larva de Tenebrio molitor (Ferreira et al, 1990b).

Ferreira et al. (1990) mostraram que, a viscosidade do meio pode alterar a distribuição subcelular de enzimas digestivas. Assim, aumentando o tempo de centrifugação a $100.000 \mathrm{xg}$ de 1 para 3 horas, a quantidade de material particulado que se sedimentava era maior. Como $\underline{T}$. molitor apresenta hemolinfa mais concentrada que a de $\underline{A}$. flavolineata, - meio de homogeneização para o fracionamento celular nesse inseto é mais concentrado e, portanto, mais viscoso, exacerbando esse efeito.

Em A. flavolineata, conforme comentado anteriormente, centrifugações a $100.000 \mathrm{xg}$ por tempos maiores aumentaram a quantidade de proteína obtida nas frações derivadas das frações particuladas. Embora a distribuição de modo geral não tenha sido alterada, o enriquecimento de LDH e $\gamma$ glutamil transferase em todas as frações solúveis é menor quando se centrifuga por 3 horas. Embora 0 
enriquecimento nas frações particuladas tenha ficado o mesmo ou até decrescido, a quantidade de atividade obtida nessas frações aumentou lárea do paralelogramo). Talvez a atividade específica tenha diminuído em alguns casos porque outras membranas, que não aquelas que contém SDH e $\gamma$ glutamil transferase se sedimentaram em maior quantidade.

A $\gamma$ glutamil transferase foi ensaiada na tentativa de encontrarmos um marcador de membrana plasmática. Embora em Trichosia pubescens (Diptera)(Espinoza-Fuentes et al., 1987), Erinnyis ello (Lepidoptera)(Santos et al., 1986) e Blabera gigantea (Dictyoptera)(Parenti et al., 1986) essa enzima ocorra exclusivamente ligada a membrana plasmática das microvilosidades intestinas, em $\underline{A}$. flavolineata (Orthoptera)essa enzima ocorre apenas parcialmente ligada a membranas. Situação semelhante ocorre em pieris brassicae (Lepidoptera) onde a $\gamma$ glutamil transferase ocorre também parcialmente ligada a membrana das microvilosidades intestinais (wolfersberger et al., 1987). De acordo com Terra (1988), as enzimas digestivas que são ligadas a membrana plasmática das microvilosidades intestinais variam entre os insetos de diferentes ordens. O mesmo parece ocorrer para uma série de marcadores de estruturas subcelulares.

Nos experimentos de centrifugação prolongada, a distribuição subcelular de amilase ficou mais semelhante a que se espera para uma enzima armazenada em grânulos de secreção e seu enriquecimento no SP3 
aumentou. Provavelmente isso ocorreu devido a sedimentação mais adequada e mais reproduzível das várias organelas nessas condições.

A distribuição da atividade hidrolítica sobre pN $\phi \beta g l u$ merece ser comentada. Os resultados apresentados nas figuras 2 e 4 estão coerentes entre si, mostrando que não há enriquecimento dessa atividade em nenhuma fração particulada. Somente na figura 3 isso ocorre. Atualmente sabemos que mais de uma enzima é responsável pela hidrólise desse substrato em A. flavolineata e que elas estão presentes nas células dos cecos anteriores. É possível que a proporção em que elas ocorram nessas células seja variável, que sua distribuição intracelular seja diferente e isso esteja levando a obtenção de resultados não coerentes.

Os resultados indicam que conseguimos obter uma fração rica em grânulos de secreção a partir dos cecos anteriores de A. Elavolineata através de centrifugação diferencial e para isso as centrifugações a $100.000 \mathrm{xg}$ devem ser de 3 horas. Provavelmente amilase, maltase e aminopeptidase estão em parte presentes dentro destes grânulos de secreção, sendo assim a secreção dessas enzimas digestivas seria por exocitose.

\subsection{Purificação das $\beta$-glucosidases de $\underline{A}$. flavolineata} A. flavolineata possui $3 \beta$-glucosidases solúveis em seu intestino médio, estas enzimas podem ser 
obtidas a partir do material regurgitado pelo gafanhoto.

Submetendo o regurgitado a uma filtração em gel em coluna de Superose 12 em um FPLC não é possível resolver as atividades enzimáticas ensaiadas (figura 5). Todos os picos de atividade são coeluídos na faixa de Mr 82.000, porém este procedimento leva a um aumento de cerca de 4 vezes nas atividades especificas (tabela 2).

Aplicando 0 material com atividade $\beta$ glucosidásica eluído da superose 12 em uma coluna de troca iônica Monol é possivel resolver 2 picos de atividade (figura 6). Um deles (Q1) ativo sobre celobiose e outro (Q2) ativo sobre octilßglu. Ambos os picos apresentam atividade sobre pN $\phi \beta g l u$. Os picos estão parcialmente sobrepostos, porém é possível coletar Q1 sem contaminação de Q2, conforme é atestado pela ausência de atividade sobre octilßglu no material reunido. Embora seja possível resolver parcialmente as atividades de $\mathrm{Q} 1$ e Q2 por eletroforese (figura 7) e deste modo obtem-se a $\beta$ glicosidase presente em $Q 2$ isenta da $\beta$-glicosidase presente em Q1. Através de eletroforese em cilindros de poliacrilamida do material Q2 é possível determinar que a $\beta$-glicosidase ativa sobre octilßglu também cliva outros alquil $\beta$-glucosídeos ( hexil, heptil, nonil, decil e undecilßglu) (figura 8).

Submetendo-se 0 material Q1 a inativação térmica a $60^{\circ} \mathrm{C}$ observa-se que a atividade sobre celobiose permanece constante, enquanto que a 
atividade sobre pN $\phi \beta g l u$ decresce cerca de $40 \%$ (figura 10A). Repetindo o mesmo procedimento de inativação agora com 0 material Q1 pré-incubado a $60^{\circ} \mathrm{C}$ por 40 minutos em uma temperatura de $65^{\circ} \mathrm{C}$ temos um perfil de inativação coincidente quando usamos tanto celobiose como pN $\phi \beta g l u$ como substratos. A inativação segue uma cinética de primeira-ordem aparente até 3 meia-vidas (figura 10B).

Assim, aparentemente, temos no material Q1 duas $\beta$ -glicosidases coeluídas. Uma delas é instável a $60^{\circ} \mathrm{C}$ e seria ativa apenas sobre pN $\phi \beta g l u$ (figura 10A). A segunda enzima seria termoestável a $60^{\circ} \mathrm{C}$ e ativa sobre celobiose e pN申ßglu, Deste modo a curva observada na figura 10A, quando utiliza-se pN $\phi \beta g l u$, como substrato seria devido a ação de 2 enzimas, uma delas instável e outra estável. A existência de uma só enzima ativa sobre celobiose e pN申ßglu é confirmada pelo perfil linear e coincidente de inativação na temperatura de $65^{\circ} \mathrm{C}$, quando usados os 2 substratos supracitados.

A existência de apenas uma forma enzimática ativa sobre octilßglu no material Q2 foi demonstrada também através de inativação térmica a $60^{\circ} \mathrm{C}$. Nessas condições obtem-se um perfil de inativação linear até 2 meia-vidas (figura 11), sugerindo a existência neste material de apenas uma forma enzimática ativa sobre octilßglu, com uma cinética de inativação de primeira ordem.

Desse modo parece que $\underline{A}$. flavolineata possui pelo menos 3 -glucosidases. Uma delas é ativa sobre 
alquilß-glucosideos, pN $\phi \beta g l u$ e salicina (figura 7), a

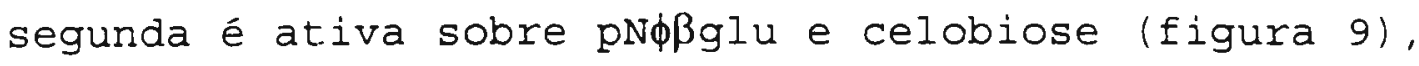
sendo estável a $60^{\circ} \mathrm{C}$ (figura 1OA) e a terceira é ativa apenas sobre pN $\phi \beta g l u$, sendo instável a $60^{\circ} \mathrm{C}$ (figura 10A). Esta última enzima não foi caracterizada.

\subsubsection{Propriedades e função da celobiase-aril $\beta$ -} glucosidase

A enzima presente em Q1 ativa sobre celobiose e pNфßglu e estável a $60^{\circ} \mathrm{C}$ hidrolisa estes 2 substratos em sitios ativos diferentes. Isto pode ser inferido a partir dos experimentos de competição entre substratos (figuras 13 e 14) e inibição com glucono $\delta$ - lactona (figuras 15 e 16).

Nos experimentos de competição entre os substratos foram usados celobiose e pN申ßglu e os padrões de competição encontrados foram do tipo competitivo linear simples, indicando que os 2 substratos ligam-se no mesmo sítio (figura 13 e 14). Quando comparamos os $\mathrm{Ki}$ e $\mathrm{Km}$ obtidos para cada um dos substratos (comparar tabelas 3 e 4 ) notamos que os $\mathrm{Ki}$ são muito maiores que os Kms. No caso da celobiose temos um $\mathrm{Ki}$ cerca de 20 vezes maior que $\mathrm{O} \mathrm{Km}$ e no caso do pN $\phi \beta g l u$ temos um $\mathrm{Ki}$ cerca de 10 vezes maior que $\circ \mathrm{Km}$ obtido (tabela 3 e 4 ).

Desse modo, ou os substratos são hidrolisados em sítios diferentes ou a enzima não atua segundo uma cinética de equilibrio rápido e $\circ \mathrm{Km}$ não é uma constante de dissociação do complexo ES. 
A hipótese da existência de 2 sítios ativos fica reforçada quando verificamos que o $\mathrm{ki}$ para glucono $\delta$ lactona é diferente quando utilizamos celobiose ou pN $\phi \beta g l u$ como substratos (tabela 4).

É importante salientar também, que $\gamma$ galactona lactona não inibe a hidrólise de pNфßglu na faixa de concentração de inibidor utilizada (0 a $60 \mu \mathrm{M}$ ) (tabela 4). Talvez este resultado signifique que pelo menos o

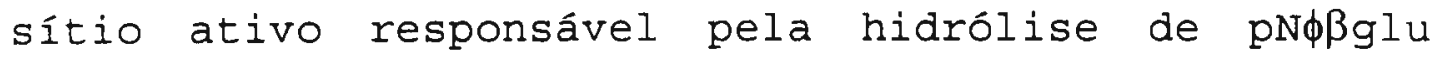
tenha preferência por substratos onde o glicone é uma glicose.

A forte inibição competitiva linear simples da hidrólise celobiose por glucono $\delta$-lactona (tabela 4) pode significar que o mecanismo de reação do sítio ativo onde é hidrolisada celobiose inclui a protonação do oxigênio da ligação glucosídica do substrato seguido pela saía de uma molécula de glicose (a qual pertence o carbono 4 da ligação glucosídica) e ataque do ion carbonium resultante por uma molécula de água.

Os dados reunidos não permitem inferir se os sitios ativos da celobiose-aril $\beta$-glucosidase localizam-se em domínios diferentes da mesma cadeia polipeptídica, como é o caso da lactase-florizinahidrolase (Leese \& Semenza, 1973; Wacker et al, 1992), .ou em diferentes subunidades da mesma enzima

Essa $\beta$-glicosidase poderia ser chamada de celobiase-aril $\beta$-glucosidase e seria uma enzima pertencente a classe 2 , segundo a classificação de Terra \& Ferreira (1994) e, além de agir sobre 


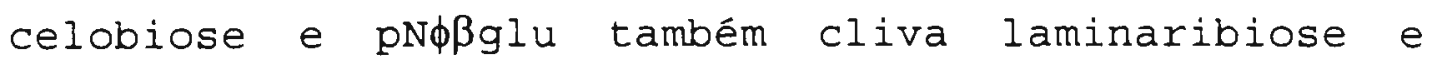
salicina (tabela 3 e figuras 18 e 20, respectivamente). Porém essa enzima prefere nitidamente celobiose, pois a relação $\mathrm{Vm} / \mathrm{Km}$ no caso deste dissacarídeo é muito maior que para os demais substratos (tabela 3 ).

Em E. ello (Lepidoptera) (Santos \& Terra, 1985) e R. americana (Dipeptera) (Ferreira \& Terra, 1983) também são encontradas $\beta$-glicosidases ativas sobre celobiose e aril $\beta$-glicosideos, porém nestes 2 insetos existem evidências lexperimentos de inativação térmica e competição entre substratos) de que todos os substratos são hidrolisados no mesmo sitio ativo, diferentemente do que parece ocorrer na celobiase aril $\beta$-glucosidase de $\underline{A}$. Elavolineata.

A celobiase-aril $\beta$-glucosidase de $\underline{A}$. flavolineata é comparável a lactase-florizina hidrolase (Leese \& Semenza, 1973) pelo fato de possuir um sítio para substratos com aglicones hidrofilicos (sitio onde é clivado celobiose) e outro para substratos com aglicones hidrofóbicos (sítio onde é clivado pN申 $\beta$ glu). No caso da enzima de mamíferos estes 2 sítios são localizados em domínios diferentes da mesma enzima (Leese \& Semenza, 1973; Wacker et al., 1992). O sitio hidrofilico hidrolisa lactose melhor que celobiose e o sítio hidrofóbico hidrolisa aril $\beta$ glicosideos, glucosilceramidas, galactosilceramidas e laminaribiose (Skovbjerg et al., 1982; Freund et al., 1991). 
A celobiase-aril $\beta$-glucosidase de $\underline{A}$. Elavolineata também hidrolisa laminaribiose, porém não é certo em qual dos seus sitios ativos. É possível que a hidrólise ocorra em seu sítio hidrofóbico, a exemplo da enzima de mamíferos que também hidrolisa nesse sítio glucosil e galactosilceramidas (Freund et al., 1991). Glucosilceramidas e galactosilceramidas não foram utilizados como substrato para A. flavolineata. A hidrólise de laminaribiose, um substrato hidrofílico, no sítio hidrofóbico da enzima pode ser explicada pela proposta de Freund et al. (1991). Segundo essa hipótese as glicosilceramidases teriam evoluido de $\beta$-glucanases (ativas sobre $\beta$-glucanas de plantas, incluíndo $\beta-1,3$ glucanas), assim explicarse-ia sua presente ação sobre laminaribiose. Quanto a hidrólise de lactose, é incerto se este substrato seria clivado pela celobiose-aril $\beta$-glucosidase de $\underline{A}$. flavolineata.

Os possiveis substratos naturais para celobiosearil $\beta$-glucosidase são a celobiose ( e talvez também cadeias curtas de $\beta-1,4$ glucanas) em seu sítio hidrofílico e laminaribiose ( e talvez também cadeias curtas de $\beta-1,3$ glucanas) no outro sítio. Ambos substratos provavelmente são encontrados no intestino de A. flavolineata como resultado da ação de celulase, laminarinase e liquenase (enzimas que ocorrem no intestino de A. flavolineata segundo Marana, Terra e Ferreira, resultados não publicados) sobre $\beta$ 1-4 glucanas, $\beta-1,3$ glucanas e $\beta-1,3,1,4$ glucanas presentes na dieta dos gafanhotos. 


\subsection{2 propriedades e função da alquil $\beta$-glucosidase de A. flavolineata}

A $\beta$-glucosidase presente no material Q2 ativa

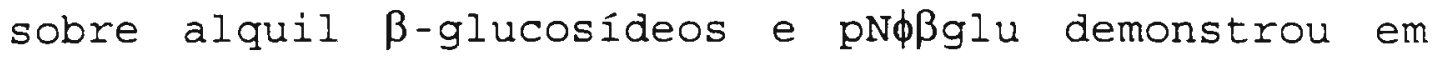
experimentos de competição entre substratos que possue apenas um sitio ativo onde são clivados todos os seus substratos (figura $20 \mathrm{~A}$ e $\mathrm{B}$ ). Isso parece verdadeiro, uma vez que os kis obtidos são semelhantes aos Kms para os mesmos compostos (comparar tabelas 5 e 6).

Esta $\beta$-glucosidase se mostrou ativa sobre uma série de alquil $\beta$-glucosídeos, onde o número de carbonos do aglicone variava de 6 até 11 (figura 8 e tabela 7). Metil $\beta$-glucosídeo foi utilizado como substrato, mas não se detectou atividade sobre ele. Nota-se na tabela 4 que o substrato clivado com maior eficiência é o nonilßglu e à medida que se aumenta ou diminui o número de carbonos no aglicone do substrato temos uma queda na eficiência de hidrólise do mesmo (ver relação Vmáx/Km na tabela 7). Este resultado sugere fortemente a exitência de um subsítio hidrofóbico de posicionamento do aglicone no sítio ativo desta alquil $\beta$-glucosidase. 0 encaixe do substrato neste subsitio seria influenciado pela hidrofobicidade e tamanho do aglicone.

A alquil $\beta$-glucosidase de $\underline{A}$. Elavolineata hidrolisa octilßglu liberando $\beta$-D-glicose (figura 22), sugerindo que a reação catalisada pela enzima 
ocorre com retenção da configuração. Este fato aliado a forte inibição competitiva linear simples causada pela glucono $\delta$-lactona (figura 21 e tabela 6), sugere que 0 mecanismo de reação desta enzima inclui protonação do substrato no oxigênio da ligação glucosídica, seguido pela saída do aglicone e ataque frontal do ion carbonium. Este mecanismo de reação é similar ao de outras $\beta$-glicosidases. Em E. ello (Lepidoptera) (Santos \& Terra, 1985) e em $\underline{R}$. americana (Diptera) (Ferreira \& Terra, 1985) também encontramos uma $\beta$-glicosidase que atua com retenção da configuração e deve apresentar um ion carbonium como intermediário no ciclo catalítico (Ferreira \& Terra, 1983)( Uma revisão mais completa sobre mecanismo de reação em glicosidases pode ser encontrada em Sinnot, 1990).

Como pode ser visto na figura 18A e 19A o perfil da curva de atividade versus concentração de substrato é sigmoidal ou hiperbólico dependendo se o substrato é octilßglu ou pN $\phi \beta g l u$, respectivamente. Este perfil sigmoidal foi observado com vários alquil Bglu que possuiam 7 a 10 carbonos no aglicone.

- perfil sigmoidal parece ser devido a uma ativação da alquil $\beta$-glucosidase pelo próprio substrato, uma vez que a adição de Triton X-100 ao meio de reação converte a sigmóide em uma hipérbole linearizável pelo plote dos duplos recíprocos (figura $18 \mathrm{~A}$ e Cl. Foi descartada assim a possibilidade da existência de múltiplos sítios com cooperatividade. $\mathrm{Na}$ enzima deve existir provavelmente um sítio de 
ligação para um ativador, espacialmente distinto do sitio ativo. Utilizando a equação de ativação não essencial (Segel, 1975) foi possível simular uma sigmóide teórica para as condições por nós utilizadas, que se ajustou perfeitamente aos dados experimentais obtidos.

A tabela 5 apresenta os parâmetros teóricos para a ativação da alquil $\beta$-glucosidase pelo octilßglu. A ligação deste substrato ao sítio de ativação leva a uma mudança no $\mathrm{Km}$ de 4 para $2,4 \mathrm{mM}$ e causa um aumento de 1,3 vezes na Vmáx, resultando na curva sigmóide quando plota-se a atividade em função da concentração de substrato.

Somente moléculas anfipáticas parecem ligar-se ao sítio ativador. Esta hipótese baseia-se no fato que

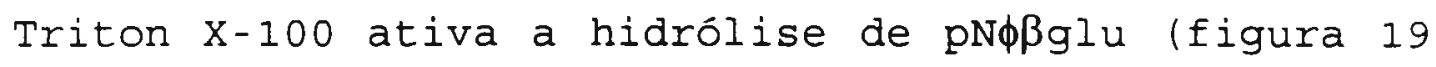
B) e muda o perfil sigmóide com octilßglu para uma hipérbole (figura 19A).

A ativação por Triton $X-100$ é completa em concentrações abaixo da CMC deste detergente (figura 19B), resultado que sugere que somente monômeros do detergente ligam-se ao sítio ativador. Esta hipótese é confirmada pelo fato que a ausência ou presença de Triton $\mathrm{X}-1000,21 \mathrm{mM}(0,9 \mathrm{CMC})$ ou $4,8 \mathrm{mM}(20 \mathrm{CMC})$ não influencia o volume de eluição da alquil $\beta$ glucosidase em filtração em gel.

A alquil $\quad \beta$-glucosidase hidrolisa preferencialmente glicose ligada a um aglicone hidrofóbico, assim sendo seus prováveis substratos naturais são glucolipídeos, tais como 
glucosilceramidas. Esta hipótese é suportada pelo fato desta enzima ser ativada por moléculas semelhantes a detergentes e hidrolisar octilßglu como descrito para glucosilceramidase (EC 3.4.1.45) (Grabowski e Dagan, 1984).

A ativação da alquil $\beta$-glucosidase por moléculas anfipáticas pode ser um mecanismo para manter a enzima altamente ativa somente na vizinhança das membranas onde encontra-se seu substrato natural e as suas moléculas ativadoras. Longe das membranas, a enzima estaria pouco ativa e assim hidrolisaria com pouca eficiência os glicosídeos vegetais que podem ser ingeridos pelo inseto. Como os aglicones são em geral mais tóxicos que o próprio glicosídeo (Yu, 1989), um mecanismo para evitar a intoxicação pode resultar de uma menor atividade da alquil $\beta$ glucosidase. Cabe lembrar que a celobiase-aril $\beta$ glucosidase, que também poderia clivar glicosídeos vegetais (possuem aglicones hidrofóbicos) em seu sítio hidrofóbico, apresenta uma atividade muito pequena sobre salicina e nenhuma sobre arbutina. Desse modo praticamente não deve hidrolisar os glicosídeos vegetais ingeridos pelo gafanhoto. 


\section{Resumo}

Nas células do ceco anterior de A.flavolineata, a secreção de enzimas digestivas parece ser mediada por vesículas de secreção e é influenciada pelo tempo decorrido após a refeição. Fracionamentos subcelulares das células do ceco anterior realizados 3h após a refeição indicaram que a amilase, maltase, pNфßglu hidrolase e aminopeptidase estão enriquecidas nas frações que contém os grânulos de secreção. $\gamma$ glutamil transferase, aminopeptidase e dipeptidase apresentaram uma forma solúvel e outra ligada a membrana.

No conteúdo do intestino de A.flavolineata foi possível detectar a presença de $3 \beta$-glucosidases: 1 , uma celobiase-aril $\beta$-glucosidase termoestável; 2 , uma aril $\beta$-glucosidase termoinstável ativa sobre $p N \phi \beta g l u$; 3, uma alquil $\beta$-glucosidase. A celobiase-aril $\beta$ glucosidase hidrolisa celobiose e aril $\beta$-glucosídeos em sítios diferentes e é mais ativa sobre celobiose e laminaribiose que sobre aril $\beta$-glucosideos sintéticos ou naturais. Moléculas anfipáticas ativam a alquil $\beta$ glucosidase, tornando esta enzima efetivamente ativa apenas na digestão de membranas. Esta enzima hidrolisa alquil $\beta$-glucosídeos com 6 a 11 carbonos no radical alquil. A celobiase-aril $\beta$-glucosidase e a alquil $\beta$-glucosidase são provavelmente responsáveis pela digestão "in vivo" de $\beta-1,4 ; \beta-1,3 ; \beta-1,3-1,4$ glucanas e glucosilceramidas, respectivamente. 


\section{Abstract}

The secretion of digestive enzymes in the anterior caecal cells of $\underline{A}$. flavolineata seems to be mediated by secretory vesicles and influenced by the period of time after a meal. Subcellular fractions of anterior caecal cells were obtained by differential centrifugation of homogenates prepared 3 hours after a meal. Amylase, maltase, pN $\phi \beta g l u$ hidrolase and aminopeptidase are found with high activities in fractions that correspond to the contents of secretory vesicles. $\quad \gamma$ glutamil transferase, aminopeptidase and dipeptidase presented soluble and membrane-bound forms.

In A. flavolineata midgut contents we found $3 \beta-$ glucosidases: 1 , a heat-stable cellobiase-aryl $\beta$ glucosidase; 2 , a heat-unstable activity against pN $\phi \beta$ glu (aryl $\beta$-glucosidase); 3 , a alkyl $\beta$-glucosidase. The cellobiase-aryl $\quad \beta$-glucosidase hydrolyzes cellobiose and aryl $\beta$-glucosides at different active sites and is more active on cellobiose and laminaribiose than on aryl $\beta$-glucosides. Amphipatic molecules activate the alkyl $\beta$-glucosidase, making the enzyme very active only during membrane digestion. This enzyme hydrolyzes alkyl $\beta$-glucosides with 6 to 11 carbons in alkyl moiety. The cellobiasearyl $\beta$-glucosidase and alkyl $\beta$-glucosidase are probably responsible for in vivo digestion of $\beta-1,4$; $\beta-1,3 ; \quad \beta-1,3-1,4$ glucans and glucosylceramides, respectively. 


\section{Referências bibliográficas}

Applebaum S.W. (1985). Biochemistry of digestion. In: Comprehensive insect physiology biochemistry and pharmacology. Editado por: Kerkut G.A. \& Gilbert L.I. vol. 4, pp $279-312$. Pergamon Press, Oxford.

Baker J.E. \& Woo S.M. (1992). $\beta$-glucosidases in the ric weevil, Sitophilus oryzae: purification, properties, and activity levels in wheat-and legume-feeding strains. Insect Biochem. Molec. Biol. 22, 495 - 504.

Bergmeyer H.U. \& Bernt E. (1974). Colorimetric assay with L-lactate, NAD, phenazine methosulfate and INT. In Methods of Enzimatic Analysis (Editado por Bergmeyer H.U.), 2nd edn, pp 579 - 582. Chemie, Weinheim.

Bradford M.M.(1976). A rapid and sensitive method for the quantification of microgram quantitaies of protein utilizing the principle of protein-dye binding. Analyt. Biochem. $72,248-254$.

Chapman R.F. (1985). Structure of the digestive system. In "Comprehensive insect physiology, biochemistry and pharmacology" Editado por Kerkut G.A. \& Gilbert L.I. vol.4, pp 165 - 211. Pergamon Press, New York. 
Chararas C., \& Chipoulet J.M. (1982). Purification by chromatography and properties of a $\beta$-glucosidase from the larvae of phrocantha semipunctata. Comp. Biochem. Physiol. 72B, $559-564$.

Chipoulet J.M. \& Chararas C. (1985). Purification and partial characterization of a cellobiase from the larvae of Rhagium inquisitor. Comp. Biochem. Physiol. $82 B, 327-332$.

Day M.F. \& Powning R.F. (1949). A study of the processes of digestion in certain insects. Aust. J. Scient. Res. (B) 2, $175-215$.

De Duve C., Pressman B.C., Gianetto R., Wattiaux K. \& Appelmans F. (1955). Tissue fractionation studies. 6 Intracelular distribuition patterns of enzymes in rat Iiver tissue. Biochem. J. 60, $604-617$.

Dow J.A.T. (1981). Countercurrent flows, water movements and nutrient absorpition in the locust midgut. $J$. Insect Physiol. 27, 579 - 585. 
Espinoza-Fuentes F.P., Ribeiro A.F. \& Terra W.R. (1987). Microvillar and secreted digestive enzymes from Musca domestica larvae. Subcellular fractionation of midgut cells with electron microscopy monitoring. Insect Biochem. 17, $819-827$.

Erlanger D.F., Kokowsky N. \& Cohem W. (1961). The preparation and properties of two new chromogenic substrates of trypisin. Arch. Biochem. Biophys. 95, $271-278$.

Evans W.A.L. (1956). Studies on the digestive enzymes of the blowfly Calliphora erythrocephala - I. Carbohydrases. Exp. Parasitol. 5, 191 - 206.

Ferreira C., Bellinelo G. L., Ribeiro A.F. \& Terra W.R. (1990). Digestive enzymes associated with the glycocalix, microvillar membranes and secretory vesicles from midgut cells of Tenebrio molitor larvae. Insect Biochem. 20, $839-847$.

Ferreira C., Marana S.R., Terra W.R. (1992). Consumption of sugars, hemicellulose, starch, pectin and cellulose by the grasshopper Abracris flavolineata. Entomol. exp. appl. $65,113-117$.

Ferreira C., Oliveira M.C. \& Terra W.R. (1990b). Compartmentalization of the digestive process in 
Abracris flavolineata (Orthoptera : Acrididae) adults. Insect Biochem. 20, $267-274$.

Ferreira C. \& Terra W.R. (1983). Physical and kinetic properties of a plasma-membrane-bound $\beta$-D-glucosidase (cellobiase) from midgut cells of an insect (Rhynchosciara americana) larvae. Biochem. J. 213, 43 - 51.

Ferreira C. \& Terra W.R. (1989). Spatial organization of digestion secretory mechanisms and digestive enzyme properties in Pheropsophus aequinoctialis (Coleoptera : (arabidae). Insect Biochem. 19, 383 - 391.

Freund J. N., Gossé F. and Raul F. (1991). Derivatives of plant Bglucans are hydrolyzed by intestinal lactose phlorizin hydrolase of mammals. Enzyme 45, 71 - 74.

Glew R.H., Gopalan V., Hubbell C., Devraj R.V., Lawson R.A., Diven W.F. \& Mannock D.A. (1991). 2,3-Di-Otetradecyl-1-0-( $\beta$-D-glucopyranosyl)-sn-glycerol is a substrate for human glucocerebrosidase. Biochem. J. $274,557-563$. 
Gopalan V., Daniels L.B., Glew R.H. \& Claeyssensi M. (1989). Kinetic analysis of the interaction of alkyl glycosides with two human Beta-glucosidases. Biochem. J. $262,541-548$.

Gopalan V., Pastuszyn A., Galey Jr. W.R. \& Glew R.H. (1992). Exolytic hydrolysis of toxic plant glucosides by Guinea pig liver cytosolic $\beta$-glucosidase. J. Biol. Chem. 267, $14027-14032$.

Grabowski G.A., Gatt S., Kruse J.G., Desnick R.J. (1984). Human lysossomal $\quad \beta$-glucosidase: Kinetic characterization of the catalytic and hydrophobic binding sites. Arch. Biochem. Biophys. 231, 144 157.

Groover Jr. P.B., Ross D.R. \& Shukle R.H. (1988). Identification and partial characterization of digestive carbohydrases in larvae of the Hessiam fly, Mayetiola destructor (Say) (Diptera : Cecidomyidae). Arch. Insect Biochem. Physiol. 8, 59 - 72.

Ito T. \& Tanaka M. (1959). Beta-glucosidase of the midgut of the silkworn Bombyx mori . Biol. Bull. 116, 95 105 .

Kelly R.B. (1985). Pathways of protein secretion in eukaryotes. Science $230,25-32$. 
Khan M.R. and Ford J.B. (1962). Studies of digestive enzyme production and its relationship to the cytology of the midgut epithelium in Disdercus fasciatus Sign. (Hemiptera, Pyrrhocoridae). J. Insect Physiol. 8, $597-608$.

La Marco K.L. \& Glew R.H. (1986). Hydrolisis of a naturally occuring $\beta$ glucoside by a broad-specificity Bglucosidase from liver. Biochem. J., 237, $469-476$.

Leese H.J. \& Semenza G. (1973). On the identity between the small intestinal enzymes phlorizin hydrolase and glycosylceramidase. J. Biol. Chem. 248, 8170 - 8173.

Lemos L.J.A., Ribeiro A.F. \& Terra W.R. (1993). A bacteria-digesting midgut-lysosyme from Musca domestica larval midguts. Insect Biochem. Molec. Biol. 22, $613-619$.

Lindroth R.L. (1988). Hydrolysis of phenolic glycosides by midgut Beta-D-glucosidases in Papilio glaucus subspecies. Insect Biochem. 18,789-792.

MC Even S.E., Slaytor M. \& O'Brien R.W. (1980). Cellobiase activity in three species of australian termites. Insec Biochem. 10, 563 - 567.

Melior J.D. \& Layne D.S. (1974). Steroid Beta-Dglucosidases. J. Biol. Chem. 249, 361 - 365. 
Moffatt M.R. \& Lehane M.J. (1990). Trypsin is stored as an inactive zymogen in the midgut of stomoxys calcitrans. Insect Biochem. 20,719-723.

Morgan M.R.J. (1975). Relatonship between gut cellobiase, lactase, aryl $\beta$-glucosidase, and aryl $\beta$-galactosidase activities of Locusta migratoria. Insect Biochem. 5, $609-617$.

Morton, R.E. \& Evans T.A. (1992). Modifications of the bicinchoninic acid proteam assay to eliminate lipid enterference in determining protein content. Analyt. Biochem. 204, $332-334$.

Nicholson J.A. \& Kim Y.S. (1975). A one-step L-amino acid oxidase assay for intestinal peptide hydrolase activity. Analyt. Biochem. 63, 110-117.

Noelting G. \& Bernfeld P. (1948). Sur les enzymes amylolytiques. III La ßamilase: dosage d'activité et controlê de l'abesence d'amylase. Helv. Chim.Acta 31 , $286-290$. 
Osiecki-Newman K., Fabbro D., Legler G., Desnick R.J. \& Grabowski G.A. (1987). Human acid $\beta$-glucosidase: use of inhibitors, alternative substrates and amphiphiles to investigate the properties of the normal and Gaucher disease ative sites. Biochim. Biophys. Acta $915,87-100$.

Palade G. (1975). Intracellular aspects of the process of protein synthesis. Science 189, $347-358$.

Parenti P., Sacchi F.V., Hanozet G.M. \& Giordana B. (1986). Na-dependent uptake of phenylalanine in the midgut of a cockroach (Blabera gigantea). J. Comp. Physiol. B 156, $549-556$.

Pócsi I. \& Kiss L. (1988). kinetic studies on the broadspecificity Beta-D-glucosidase from pig kidney. Biochem. J. 256, $139-146$.

Pratviel-Sosa F., Clermont S., Percheron F. \& Chararas C. (1987). Studies on glycosidases and glucanases in Thaumetopoea pityocampa larvae. II purification and some properties of a broad specificity $\beta-D-$ glucosidase. Comp. Biochem. Physiol. 86B, 173 - 178 .

Quinn P.J. \& Williams, W.P. (1983). The structural role of lipids in photosynthetic membranes. Biochim. Biophys. Acta $737,223-266$ 
Read S.M. \& Northcote D.H. (1981). Minimization of variation in the response to different proteins of the comassie blue $G$ dye-biding assay for protein. Analyt. Biochem. 116, $52-64$.

Santos C.D., Ribeiro A.F. e Terra W.R. (1986). Differential centrifugation, calcium precipitation and ultrasonic disruption of midgut cells of Erinnyis ello caterpillars. Purification of cell microvilli and inferences concerning secretory mechanisms. Can. J. Zool. $64,490-500$.

Santos C.D. \& Terra W.R. (1984). Plasma membraneassociated amylase and trypsin: intracellular distribution of digestive enzymes in the midgut of the cassava hornworm, Erinnyis ello. Insect Biochem $14,587-595$.

Santos C.D. \& Terra W.R. (1985). Physical properties substrate specificities and a probable mechanism for a $\beta$ Dglucosidase (cellobiase) from midgut cells of the cassava hornworm (Erinnyis ello). Biochim. Biophys. Acta 831, $179-185$.

Schray, K.J. \& Benkovic, S.J. (1978). Anomerization rates and enzyme specificity for biologically important sugars and sugar phosphates. Accounts Chem. Res. 11 , $136-141$.

Segel I.H. (1975). Enzyme kinetics. Wiley, New York. 
Semenza G. (1986). Anchoring and Biosynthesis of stalked brush border membrane proteins: glycosidases and peptidases of enterocytes and renal tubuli. Annu. Rev. Cell Biol. 2, $255-313$.

Simpson S.J. (1990). The pattern of feeding. In "Biology of grasshoppers". Editado por Chapman R.F. \& Joern A., pp 73-103. Willey, New York.

Sinnott, M.I. (1990). Catalytic mechanisms of enzymic glycosil transfer. Chem. Rev. 90, 1171 - 1202.

Skovbjerg H., Norén O., Sjostrom H., Danielson E.M. and Enevoldsen B.S. (1982). Futher characterization of intestinal lactase/phlorizin hydrolase. Biochim. Biophys. Acta 707, $89-97$.

Terra W.R. (1988). Physiology and biochemistry of insect digestion: an evolutionary perspective. Brazilian $\mathrm{J}$. Med. Biol. Res. 21, 675 - 734 .

Terra W.R. (1990). Evolution of digestive systems of insects. Annu. Rev. Entomol. 35, $181-200$.

Terra W.R. \& Ferreira C. (1994). Insect digestive enzymes: properties, compartmentalization and function. Comp. Biochem. Physiol. (no prelo). 
Terra W.R., Terra I.C.M., Ferreira C. \& De Bianchi A.G. (1979). Carbodiimide-reactive carboxyl groups at the active site of an insect midgut trehalase. Biochim. Biophys. Acta 571, $79-85$.

Terra W.R., Valentim A. \& Santos C.D. (1987). Utilization of sugars, hemicelulose, starch, protein, fat and minerals by Erinnyis ello larvae and the digestive role of their midgut hydrolases. Insect Biochem. 17, $1143-1147$.

Trumbo P.R., Banks M.A. \& Gregory III J.F. (1990). Hydrolisis of pyridoxine-5'-Beta-D-glucoside by a broad-specificity Beta-glucosidase from mammalian tissues. Proc. Soc. Exper. Biol. Med. 195, $240-246$.

Ugolev A. M., Timofeeva N.M., Roshchina G.M., Smirnova L.F., Gruzdkov A.A. \& Gusev S.A. (1990). localization of peptide hydrolysis in the enterocyte and the transport mechanisms of apical membrane. Comp. Biochem. Physiol. 95A, 501-509.

Ugolev A.M. \& Tsvetkova V.A. (1986). The intestinal glycocalyx. In the Molecular and cellular basis of digestion. (Ed. by Desnuelle P., Sjostrom H. \& Noren o.) pp 413-419, Elsevier, Amsterdan.

van weely S., Brandsma M., strijland A., Tager J.M. \& Aerts J.M.F.G. (1993). Demonstration of the existence of a second, non-lysosomal glucocerebrosidase that is 
not deficient in Gaucher disease. Biochim. Biophys. Acta $1181,55-62$.

Vonk J.H. \& western J.R.H. (1984). Comparative biochemistry and physiology of enzymatic digestion. Academic Press, New York.

wacker H., Keller P., Salchetto R., Legler G. \& Semenza G. (1992). Location of the two catalytic sites in intestinal lactase-plorizin hydrolase. Comparison with sucrase-isomaltase and with other glycosidases, the membrane ancor of lactase-phlorizin hydrolase. J. Biol. Chem. 267, $18744-18752$.

Willingham M.C. \& Pastan I. (1984). Endocytosis and exocytosis: current concepts of vesicles traffic in animals cells. Int. Rev. Cytol. 92, $51-92$.

wolfersberger M., Luethy P., Maurer A., Parenti P., Sacchi F.V., Giordana B. and Hanozet G.M. (1987). Preparation and partial characterization of amino acid transporting brush border membrane vesicles from the larval midgut of the cabbage butterfly (pieris brassicae). Comp. Biochem. Physiol. 86A, $301-308$.

Wood A.R. \& Lehane M.J. (1991). Relative contributions of apocrine and merocrine secretion to digestive enzyme release from midgut cells of stomoxys calcitrans (Insecta : Diptera). J. Insect Physiol. 37, 161 166. 
Yu S.J. (1989). Beta-D-glucosidase in four phytophagous Lepidoptera. Insect Biochem. 19, $103-108$. 